\title{
AS TRANSFORMAÇÕES DA ESCUTA A PARTIR DA UTILIZAÇÃO DAS MÍDIAS PORTÁTEIS
}

\author{
Dissertação apresentada à Universidade de São \\ Paulo - Escola de Comunicação e Artes - \\ como exigência parcial para a obtenção do \\ título de Mestre, junto ao Programa de Pós- \\ Graduação em Música; Área de Concentração: \\ Sonologia.
}

Orientadora: Prof ${ }^{\mathrm{a}}$. Dr ${ }^{\mathrm{a}}$. Heloísa de Araújo Duarte Valente

SÃO PAULO

2014 
Nome: SANTOS, Otávio L.

Título: As transformações da escuta a partir da utilização das mídias portáteis

Dissertação apresentada à Escola de Comunicação e Artes da Universidade de São Paulo como exigência parcial para a obtenção do título de Mestre em Música.

Aprovado em:

Banca Examinadora:

Prof. Dr. Instituição:

Julgamento: Assinatura:

Prof. Dr. Instituição:

Julgamento: Assinatura:

Prof. Dr. Instituição:

Julgamento: Assinatura: 
À Cristiane e Luana 


\section{AGRADECIMENTOS:}

À CAPES (Coordenação de Aperfeiçoamento Pessoal de Nível Superior) pela bolsa concedida.

Agradeço à Prof. ${ }^{a}$ Heloísa de Araújo Duarte Valente pela confiança e apoio desde o primeiro momento dessa jornada. Pela compreensão e força ao longo da caminhada. Pela amizade, experiência e os bons momentos de partilha e aprendizado. Por me permitir crescer como pesquisador e como pessoa, não me deixando cair diante das dificuldades.

Ao Prof. Fernando Iazzetta e ao Prof. José Eugênio Menezes, sempre solícitos e gentis. Agradeço por todo incentivo e pelos sempre importantes direcionamentos para essa pesquisa. Os resultados aqui apresentados não seriam obtidos sem essa colaboração. Pela experiência e conhecimento partilhados.

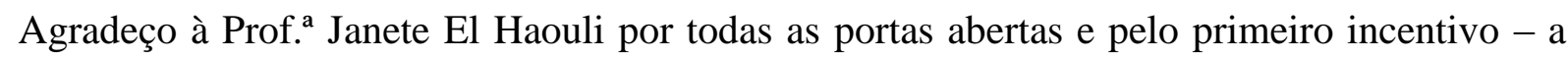
partir de um encontro casual - a cursar o mestrado em Música na Universidade de São Paulo, sem a qual talvez essa empreitada não tivesse se iniciado.

A realização deste trabalho não seria possível sem a colaboração dos professores Diósnio Machado Neto (CMU), Victor Aquino G. Correa (CRP) e Arlindo Machado, Almir Almas, Maria Dora Mourão e Eduardo Santos Mendes (CTR), que contribuíram imensamente com suas ricas experiências e incentivo à pesquisa.

Ao sempre disposto João Catarino (PPGMUS), que desde o início, e em diversos momentos, me auxiliou com paciência e descontração mesmo diante das situações mais adversas.

À minha esposa Cristiane e minha filha Luana, pela constante motivação, apoio e compreensão, mostrando que tudo é possível quando se tem com quem contar.

A meus pais, que sempre confiaram em meu trabalho e sustentaram meus sonhos de pé.

A Deus, meu motivo maior. 


\section{RESUMO}

\section{As Transformações da Escuta a Partir da Utilização das Mídias Portáteis}

Com o passar dos anos, o hábito da escuta musical passou por diversas transformações, comumente relacionadas a tendências sociais e inovações tecnológicas. No início do século XX, a relação homem-máquina-escuta se elevou a um novo patamar. No início do século XXI, o predomínio das mídias portáteis (aqui delimitadas a iPods, tablets e smartphones) promove novas transformações na prática da escuta musical, gerando consequências musicais e sociais consideráveis. Partindo do Walkman, um dos maiores ícones da portabilidade do século passado, esse trabalho analisa a sucessão das principais mídias e formatos - com seus respectivos impactos culturais - até alcançar a década de 2010, dominada pelo formato MP3 e já fundada em uma peculiar prática de escuta musical. Através de extensa pesquisa bibliográfica e audiovisual, este trabalho se dispõe a refletir sobre as principais transformações músico-sociais originadas a partir da utilização massiva das mídias portáteis (como meio predominante de prática da escuta musical urbana), tornando mais visível a relevância de estudos aprofundados na área.

Palavras-chaves: escuta; cultura das mídias; portabilidade; tecnologia digital; acessibilidade; mídia móvel 


\section{ABSTRACT \\ Changings of the listening process by the use of portable media}

Throughout the years, musical listening habits have suffered many changings, usually related to social tendencies and technological improvements. In the beginning of the 20th century, the man - machine- listening relation achieved a new level. During the first decades of the 21th century, the ubiquity of portable media (defined in this work as iPods, tablets and smartphones) promotes new alterations in the listening habits, therefore social and musical impacts. Beginning from the Walkman, one of last century's most acclaimed icons of portability, this work analyses the sequence of the following main devices and formats - each one with its particular cultural impacts - until reaching the 2010s, a decade dominated by MP3 and based on a unique musical listening experience. This work intends to reflect, through extensive research and bibliographical discussion, the main musical and social reorganization originated by the massive use of these devices as the urban leading musical listening vehicle, increasing the visibility and the relevance of more detailed researches in this area.

Keywords: listening; media culture; portable media; digital technology; accessibility; mobile devices 


\section{Sumário}

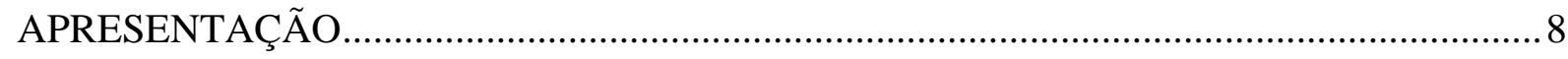

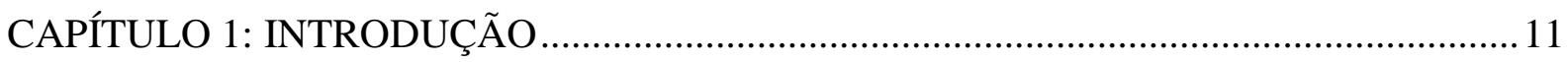

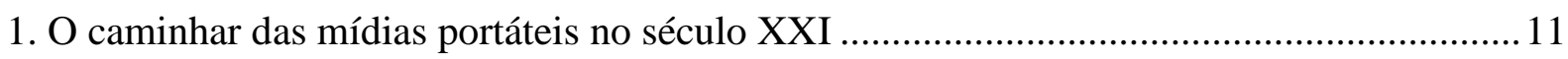

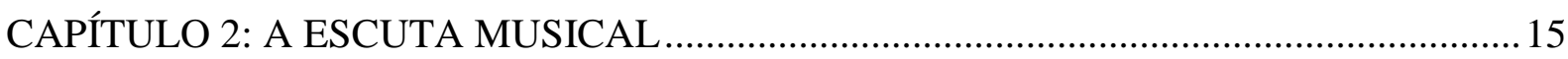

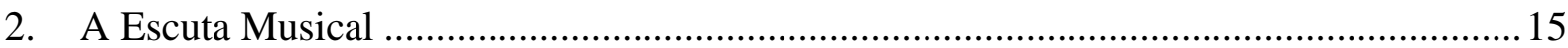

2.1 Tipos de escuta - de Adorno a Stockfelt: convergências e divergências .................... 17

2.2 A música mecanizada e a escuta mediada ............................................................ 22

2.3 Os predecessores das mídias portáteis e a influência cultural .................................. 32

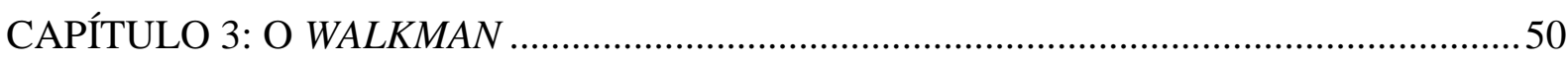

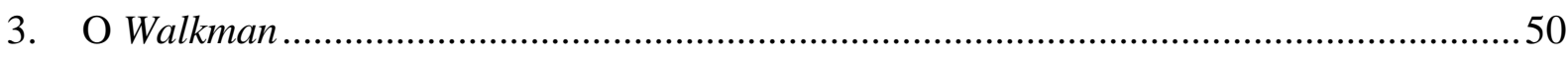

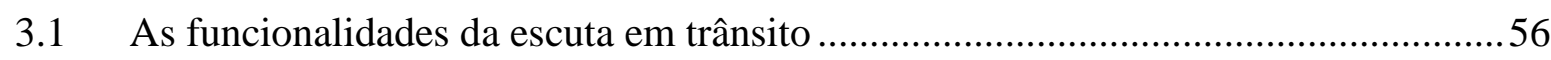

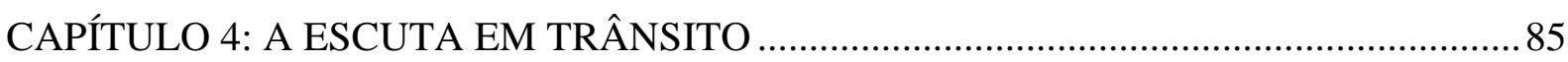

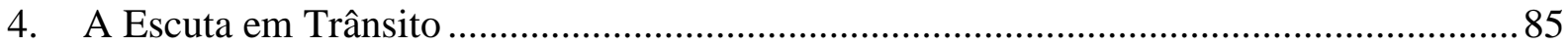

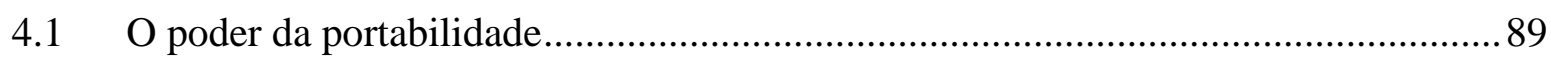

4.2 As três consequências sociais e musicais da escuta em movimento..........................94

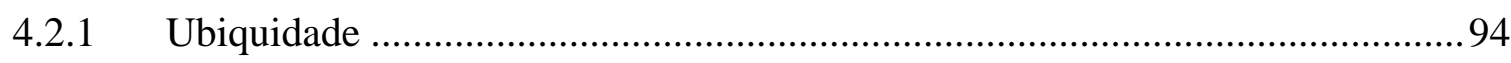

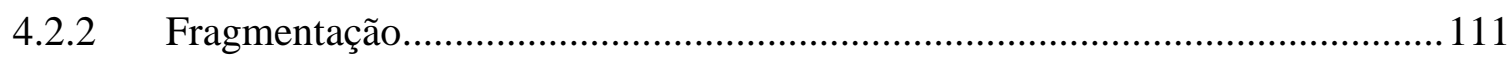

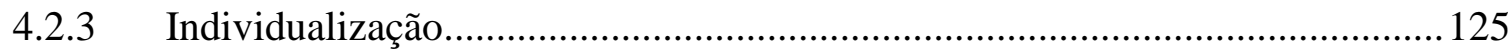

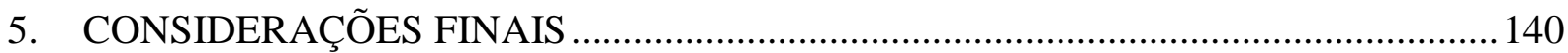

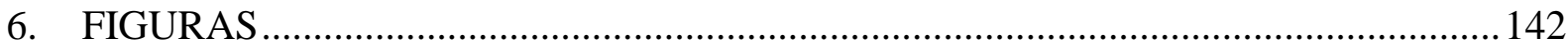

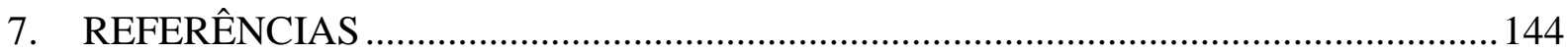




\section{APRESENTAÇÃO}

Graduei-me em Licenciatura em Música pela Universidade Estadual de Londrina no ano de 2004. Após a conclusão do curso e atuar no ramo publicitário como proprietário de uma produtora de áudio em Londrina (PR), busquei aprimorar-me na área de trilha sonora nos Estados Unidos. Assim, em 2010 concluí uma Especialização em Trilha Sonora para Cinema e TV na University of California Los Angeles (UCLA), tendo, após o término do curso, trabalhado junto ao premiado compositor canadense Trevor Morris, responsável pela trilha musical de diversos shows da televisão americana como The Borgias, The Tudors - com o qual ganhou um Emmy de melhor trilha sonora original - e Vikings, além de projetos como Piratas do Caribe, dentre outros filmes.

Retornando para o Brasil, passei a atuar como compositor de trilhas musicais, tendo trabalhado em filmes e documentários nacionais e internacionais e lecionado em diversos cursos e pós-graduações voltadas para Música ou áreas afins.

Percebi a necessidade de me aprofundar em questões de ordem reflexiva e prática acerca de experiências musicais relacionadas à minha carreira profissional, primeiramente com a finalidade de obter maior embasamento teórico e bibliográfico que fundamentasse minha prática profissional, e posteriormente para iniciar uma qualificação que me permitisse, em um futuro próximo, trabalhar no meio acadêmico musical. Assim, iniciei o Mestrado em Sonologia pela Universidade de São Paulo, sob orientação da Prof ${ }^{a}$. Dr ${ }^{a}$. Heloísa de Araújo Duarte Valente, Programa que curso como bolsista da CAPES. Como membro do Musimid Centro de Estudos de Música e Mídia, tenho participado no desenvolvimento de subprojetos. ${ }^{1}$

A iniciativa para essa pesquisa se deu no momento em que percebi que os cidadãos das grandes cidades são mais vistos pelas ruas com suas mídias portáteis a tiracolo do que com a companhia real de outras pessoas. Muitos autores (SIMMEL, 1950; BAUMAN, 2013; MENEZES, 2007; IAZZETTA, 2009, VALENTE, 2007; LÉVY, 2010) se debruçaram sobre a modernidade e seus desdobramentos sociais e musicais ao longo dos séculos XX e XXI. Não seria possível que tal prática tão comum, da escuta em deslocamento, não estivesse agregando

\footnotetext{
${ }^{1}$ Parte do capítulo 2 desta dissertação é resultado parcial do projeto Una musica dolce suonava...: memória e nomadismo na canção ítalo-paulistana, coordenado pela Prof. ${ }^{a}$ Dr $^{a}$ Heloísa Valente (coordenadora do MusiMid). Este projeto aborda um novo grupo de canções, através de subprojetos conduzidos, igualmente, por participantes do MusiMid. Parte de um grupo de canções, de origem italiana e sua presença e suas repercussões junto à comunidade de imigrantes italianos, ítalo-descendentes, na capital paulista. O ponto de partida: o conceito de "canção das mídias" como elemento ativo e de forte presença na cultura.
} 
novos valores e estabelecendo novos hábitos de escuta entre os usuários. E ao mesmo tempo, parece haver uma reciprocidade, em que esses ouvintes interferem também no fluxo dos costumes e comportamentos sociais da cidade.

Assim foi proposto esse estudo, com o objetivo de levantar reflexões e tentar elucidar como estaria se estabelecendo essa relação simbiótica entre os usuários das mídias portáteis e o ambiente externo aos fones de ouvido, aproveitando o fato de não se ter em abundância trabalhos específicos com essa temática.

O capítulo I introduz o tema partindo da relação homem-máquina estabelecida no final do século XIX. Apresenta brevemente o modo de vida do século XXI e o contexto em que os ouvintes passaram a exercitar a escuta, de modo completamente - mas não exclusivamente - mediado tecnologicamente e através das mais diversas mídias portáteis.

O capítulo II é centrado na escuta em si. Apresenta um panorama geral das diferentes formas de se ouvir, sempre contextualizadas com a evolução das mídias de reprodução sonora de cada época. Além de trazer uma visão geral da escuta musical, discorre sobre algumas teorias relacionadas à escuta musical, como a de Adorno ((1973) 2011), Peter Szendy (2008), Barry Truax (2001), Rose Subotnik (1989) e Ola Stockfelt (2004).

O capítulo traz também discussões acerca do desenvolvimento das mídias, desde o fonógrafo até os iPods, passando pelo som mecanizado (BARTÓK, 1985) e as paisagens sonoras urbanas e rurais (SCHAFER, 1997). Nessa seção do trabalho, dedico parte do texto a algumas mídias específicas, como o disco em vinil e o $\mathrm{CD}$, discutindo seus impactos culturais e tecnológicos, posicionando-os como alguns dos pilares das mídias posteriores e ressaltando seus aspectos de "formadores culturais".

O capítulo apresenta também uma análise de caso vinculada ao projeto Una musica dolce suonava...: memória e nomadismo na canção ítalo-paulistana, coordenado pela Prof. ${ }^{\text {a }}$ Dr $^{\mathrm{a}}$ Heloísa Valente. Trata-se de reflexões sobre a escuta musical no contexto dos imigrantes italianos, ítalo-descendentes, na capital paulista. Através de entrevistas, os depoimentos foram vinculados a conteúdos apresentados na dissertação, a fim de melhor compreender aquela realidade sob uma perspectiva musicológica centrada na escuta musical.

O capítulo III se fundamenta no aparato Walkman. Iniciando um recorte histórico para então se chegar às mídias portáteis da década de 2010, a proposta se deveu à importância do Walkman enquanto agente formador cultural. Esse aparelho iniciou um novo hábito de escuta musical, e em muito se assemelha às mídias posteriores discutidas nessa pesquisa. Também o Walkman inovou em questões mercadológicas, como estratégias de marketing, cujas técnicas até hoje são utilizadas em campanhas de empresas pertencentes a esse nicho de 
mercado. Michael Bull (2000; 2005) foi o autor principal escolhido para se fundamentar a discussão em relação à portabilidade e os tipos de escuta derivados dela no Walkman.

O capítulo IV encerra a dissertação dedicando-se exclusivamente às mídias portáteis do final do século XX até a década de 2010. Iniciando-se no advento do MP3, propõe três consequências sociais e musicais da escuta em trânsito: a ubiquidade, a fragmentação e a individualização, discussões essas que englobam aspectos não só musicais, mas também permeiam reflexões psicológicas e sociológicas. 


\title{
CAPÍTULO 01
}

\section{INTRODUÇÃO}

\section{O caminhar das mídias portáteis no século XXI}

Inicio este texto tomando emprestadas as ideias de Zygmunt Bauman, importante sociólogo polonês, que vem dedicando vários estudos ao tema da fluidez da modernidade:

\begin{abstract}
Uso aqui a expressão 'modernidade líquida' para denominar o formato atual da condição moderna, descrita por outros autores como 'pósmodernidade'. [...] O que torna líquida a modernidade, e assim justifica a escolha do nome, é sua 'modernização' compulsiva e obsessiva, capaz de impulsionar e intensificar a si mesma, em consequência do que, como ocorre com os líquidos, nenhuma das formas consecutivas de vida social é capaz de manter seu aspecto por muito tempo. 'Dissolver tudo que é sólido' tem sido a característica inata e definidora da forma de vida moderna desde o princípio; mas hoje, ao contrário de ontem, as formas dissolvidas não devem ser substituídas (e não o são) por outras formas sólidas - consideradas 'aperfeiçoadas', no sentido de serem até mais sólidas e 'permanentes' que as anteriores, e portanto até mais resistentes à liquefação. No lugar de formas derretidas, e portanto inconstantes, surgem outras, não menos - se não mais suscetíveis ao derretimento, e portanto também inconstantes. (BAUMAN, 2013: 16)
\end{abstract}

Em poucas palavras, Bauman descreve de maneira objetiva o caminhar do século XXI, período caracterizado pela massiva influência da internet e que pede um novo estilo de vida dos cidadãos, especialmente das metrópoles. Juntamente com o fluxo de evolução tecnológica, os meios de difusão musical - as mídias ${ }^{2}$ de reprodução sonora também têm se adequado a esse modo de vida móvel e inconstante. Os fabricantes de aparelhos têm sabido desenvolver tecnologias permitindo uma expansão das funções, ao passo que os usuários têm se permitido tirar o maior proveito desse meio. Enquanto algumas mídias pré-existentes se adaptam ao padrão virtual, outras nascem nesse ambiente, como o MP3. A escuta musical atrelada às mídias, por sua vez, encontra-se em franco processo de transformação, visto que nunca antes ela foi praticada sob as condições encontradas a partir da década de 2000. A escuta tomou um caráter itinerante, móvel e cheio de possibilidades- o que não surpreende quando analisamos a sociedade dentro da qual essa escuta foi gerada.

\footnotetext{
${ }^{2}$ Utilizaremos o termo "mídia", forma aportuguesada do inglês. Diferentemente de meios de comunicação de massa, as mídias pressupõem uma atitude interativa, por parte do usuário (SANTAELLA, 1996).
} 
No início do século XXI testemunhamos alguns desdobramentos de um estopim tecnológico ocorrido na virada para o século anterior, e especialmente o advento da internet permitiu ao cidadão metropolitano dividir seu tempo com o ambiente virtual.

A aparente monotonia de um sujeito diante de uma tela de computador, no entanto, pode ser enganadora. Enquanto mira calmamente sua tela, uma tempestade de informações podem o estar levando a um estado de caos interior, gerando resultados (pessoais, psicológicos e externos) bastante distintos e marcantes ${ }^{3}$.

As mídias portáteis contemporâneas consideradas neste trabalho são os smartphones, iPod e tablets e sua forma de utilização refletem com clareza esse cenário. Uma verdadeira e muito perceptível transformação acontece dentro da sociedade, especialmente no público jovem, principal usuário destas mídias. Estas conduzem a uma forma de pensar, uma forma de ser no mundo. É o que significo. É uma filosofia de vida que, ao contrário do ambiente em que existe (virtual), gera resultados absolutamente reais e concretos, que afetam desde o aspecto psicológico do indivíduo até sua vida financeira.

\section{Os modos de vida após a introdução das máquinas}

A temática central desse trabalho é a escuta mediada por aparelhos portáteis. No entanto, a fim de elucidar com bases mais sólidas as posteriores discussões que permeiam a escuta, faz-se necessário uma breve introdução ao modo de vida sobre o qual a escuta se desenvolve.

Se durante um período da história o homem não escutava por intermédio de meios tecnológicos, hoje a escuta mediatizada revela ser a prática dominante. Mas não somente escutar, mas interagir com o material sonoro. Os instrumentos virtuais em forma de aplicativos de smartphones e tablets viabilizam a iniciação musical a qualquer indivíduo munido do artefato apropriado. Basta um software instalado e se tem uma orquestra sinfônica ao alcance dos dedos. Da mesma forma uma sanfona, um piano, violão ou flauta. A música se tornou disponível a qualquer um, inclusive àqueles que não têm acesso aos instrumentos musicais ou a escolas de música. Isso não significa, absolutamente, que essa seria a

\footnotetext{
${ }^{3} \mathrm{O}$ psiquiatra americano Jerald Block (2008), em artigo denominado Issues for DSM-V: Internet Addiction, defende que o vício na internet já parece apresentar méritos suficientes para ser adicionado ao DSM-V (Manual Diagnóstico e Estatístico de Transtornos Mentais), afirmando que conceitualmente o diagnóstico é de espectro compulsivo-impulsivo que se estende para uma utilização tanto online quanto off-line do computador (2008). Um exemplo desse risco é relatado por GORRITI (2013), narrando o caso um jovem que há cinco anos (20082013) não sai de casa devido ao vício pelo computador.
} 
aproximação adequada, ideal ou mesmo a substituição ao instrumento musical, mas não deixa de representar uma possibilidade apresentada pelas mídias portáteis.

O contato musical virtual é limitado. Como exemplo, vejamos alguns aspectos da interação entre o usuário e o instrumento. A interação virtual redesenha todos os instrumentos enquadrando-os em uma mesma forma, o de uma tela plana, privando o usuário de ter contato com o instrumento em seu formato e textura originais. Além disso, não há qualquer possibilidade de manuseio e experimentação além das notas pré-determinadas pelo aplicativo. A maneira de se tocar também é unificada, e todos os instrumentos acabam por serem executados da mesma forma: arrastando-se os dedos sobre a tela do aparelho. Fernando Iazzetta (2005), discorrendo acerca da reelaboração da produção e escuta musical proporcionada a partir da instrumentalização musical trazida pelos computadores pessoais, afirma:

\begin{abstract}
Tornou-se possível fazer música em qualquer lugar, na poltrona de um avião, na mesa de um café, no sofá da sala, ou - porque não? - numa sala de concerto. O laptop computer, o computador apoiado sobre as coxas, é ao mesmo tempo estúdio, ferramenta de composição, gerador sonoro, arquivo de músicas e aparelho de som, tudo isso ao mesmo tempo, tudo isso sobre as coxas, e controlado por um teclado mais rudimentar do que o que qualquer músico tenha tocado em tempos anteriores. (2005: 1242)
\end{abstract}

Em suma, vê-se por toda parte a liquidez contemporânea descrita por Bauman (2003; 2004; 2007; 2013). Na mídia televisiva, a tecnologia deixa de ser analógica e passa a ser digital, exigindo a adequação dos aparelhos de televisão através de conversores digitais. Às próprias transmissões televisivas têm sido acrescidos recursos visuais de animações e computação gráfica. A previsão do tempo de um telejornal apresenta globos em três dimensões com animações de chuva e sol, bem como correntes de vento e outros fatores meteorológicos. Assim também programas de toda natureza, como a transmissão de um jogo de futebol, têm se utilizado de inúmeros recursos visuais a fim de dinamizar a apresentação do evento, seja na escalação dos times, em anúncios de patrocinadores ou em análises táticas no intervalo da partida.

No campo da música, compositores como Erik Satie e Karlheinz Stockhausen já incorporavam os sons da máquina em suas composições, elevando-as ao mesmo patamar qualitativo de um instrumento musical, tornando-as assim essenciais para a execução de algumas peças. Satie, no balé Parade (1917), utilizou-se de uma máquina de escrever e sirenes como parte do naipe de percussão. Já Stockhausen, na obra HelikopterStreichquartett (Quarteto de cordas com helicópteros), lança mão da altitude dos helicópteros 
para diferenciar um momento musical do outro, ao passo que o som das máquinas varia de acordo com a altitude em que cada uma se encontra.

A tecnologia das máquinas no contexto musical foi se ampliando ao longo das décadas: desde a criação de batidas eletrônicas de músicas techno até experiências musicais

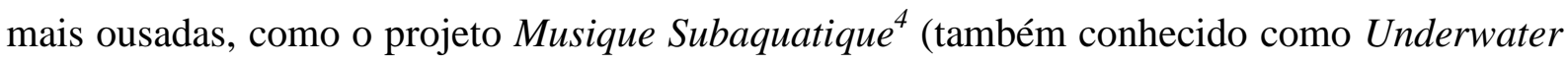
Music ou Música sob a água ${ }^{5}$ ), do compositor francês Michel Redolfi, em que músicas são transmitidas, através de mediação eletrônica, debaixo d'água para ouvintes que flutuam na superfície da piscina ou do mar, com seus ouvidos submersos.

Uma nova tecnologia de escuta ambulante gera, a partir do momento em que se dissemina no uso popular, mudanças comportamentais que vão desde a privação do indivíduo do convívio social até a alteração de hábitos e valores cotidianos como, por exemplo, o que tem ocorrido com a prática da escuta musical. O que se quer aqui ressaltar não é um juízo de valor acerca da natureza dessas novas tecnologias, mas as mudanças ocorridas a partir de uma análise das formas com que são utilizadas, bem como as consequências desse uso.

\footnotetext{
${ }^{4}$ http://www.redolfi-music.com/index_n.htm.

${ }^{5}$ Tradução livre realizada pelo próprio autor deste trabalho, não correspondente ao nome oficial do projeto em português.
} 


\section{CAPÍTULO 2}

\section{A ESCUTA MUSICAL}

\section{A Escuta Musical}

Desde antes do nascimento já somos capazes de ouvir. Estudos cognitivos realizados desde antes da década de 1990 (HETLER, 1985; ABRAMS, 1995), revelaram que “[...] com vinte e seis semanas de vida, a maioria dos fetos já responde, através do aumento da frequência cardíaca, a estímulos sonoros, indicando assim já serem hábeis a perceber sons" (ABRAMS, 1995: 83). Ainda que de maneira limitada, principalmente pela barreira física interposta entre o ouvido do feto e o ambiente externo, este já escuta a voz dos pais e alguns sons externos. Também escuta, de uma maneira mais clara, sons de seu ambiente interno, como sua circulação sanguínea e digestão. O ambiente sonoro de um feto é "[...] altamente dominado pela voz da mãe e por outros barulhos internos, permeados por uma rica variedade de sons rítmicos e tonais" (ABRAMS, 1995: 83). Não só o feto escuta, mas reage a estes sons.

O antropólogo Christoph Wulf também afirma que “[...] a partir da idade de quatro meses e meio, um feto é capaz de reagir a estímulos sonoros" (2007: 1). O nervo auditivo já está em funcionamento e a orelha já foi completamente desenvolvida. Mesmo de forma limitada, este já tem contato com os sons do mundo à sua volta.

Diz Wulf que “[...] o sentido do ouvido se desenvolve muito antes que o sentido da visão, e muito antes dos outros sentidos começarem a funcionar" (2007: 1), desempenhando durante toda nossa vida um importante papel: a interiorização dos sons externos, pois “[...] pela intermediação do ouvido, barulhos do exterior chegam ao interior. Mundos de sons exteriores tornam-se mundos de sons interiores" (WULF, 2007: 2).

Não há escuta sem assimilação, e não há assimilação sem a interiorização. O grau de interiorização e consequentemente de assimilação de um som escutado pode variar, mas isso não evitará que o som seja ouvido. O ouvido é, dessa forma, o canal que nos mantém em sintonia com o mundo externo, afinal mesmo durante o sono "[...] ficamos ligados ao mundo exterior graças ao ouvido" (WULF, 2007: 2).

Entretanto, o fato do sentido da audição ser o primeiro a se desenvolver não significa que é independente dos demais. Quando se trata de escuta, e aqui já dentro do contexto musical, é necessário compreender que o ouvir engloba uma atitude multissensorial. Como aponta o compositor e pesquisador Fernando Iazzetta, “[...] não há escuta sem visão, sem tato, 
sem olfato. [...] se ouve também com o corpo, com os olhos, e mais, com as lembranças, com as sensações" (2009: 37).

Com o objetivo de aprofundar posteriormente - Capítulos 3 e 4 - em questões práticas da escuta musical mediada pelas mídias portáteis, faz-se necessária uma breve introdução à experiência da escuta em si, seu desenvolvimento e análises acerca de alguns dos tipos de escuta musical.

\section{A prática da escuta}

Durante muitos séculos, a escuta musical esteve diretamente ligada à visão e à presença física do intérprete, de maneira que os ouvintes eram habituados a escutar música somente quando na presença dos músicos. O repertório de concerto era escutado somente nas salas de concerto, e uma sonata de Beethoven para piano somente na presença de um pianista, como descreve o musicólogo Ola Stockfelt:

Há não muito tempo atrás, era necessário irmos a uma ópera para se escutar ópera, e a única maneira de se ouvir um violão era sentando próximo ao intérprete. (2004: 90)

O início do século XX trouxe mudanças que afetaram e modificaram profundamente a experiência da escuta musical. Com a emergência das máquinas, aparelhos de reprodução sonora passaram a ser desenvolvidos, como o fonógrafo, o gramofone, o rádio, o toca-discos, até as mídias portáteis do século XXI como os iPods e smartphones.

O professor e escritor Tim Wu (2012) acredita que as invenções de cada época, sejam elas o rádio, a televisão ou o cinema, no momento em que são lançadas causam um grande estranhamento, um certo pavor e uma inquietação em seus receptores, até que esses se acostumem com a novidade.

Para $\mathrm{Wu}$, cada uma das invenções, quando lançadas em seus respectivos tempos, promove uma visão revolucionária acerca dos impactos causados por elas. No entanto, o que ocorre é que após algum tempo tudo se assenta, e a antes ameaçadora e promissora inovação passa a ocupar seu devido lugar em um ciclo de manutenção da estrutura social.

Ao tratar de ciclo, sob a perspectiva de $\mathrm{Wu}$, podemos inferir que nada escapa a essa roda-viva, inclusive a onipotente internet. Estaria ela - com sua supremacia no início do século XXI - também fadada a tornar-se parte desse ciclo, assentando-se e servindo de pavimento ou fundação para algo ainda por vir? 
A descrição desse ciclo proposta por Wu pode ser também aplicada à prática da escuta musical, pois esta se encontra vinculada aos aparelhos midiáticos surgidos dentro de um contexto social. Conforme as mídias evoluíam, os hábitos de escuta vinculados a elas também necessitavam serem transformados, e assim como as invenções, um modo de escuta que em um primeiro momento poderia parecer intimidador, logo viria a se tornar habitual. Essas transformações - bem como uma análise das práticas de escuta do início do século XXI vinculadas às mídias portáteis- constituem o tema central deste trabalho, o qual se debruçará sobre diversas perspectivas diferentes sobre ele objetivando uma melhor compreensão da temática.

Para fins de esclarecimento conceitual e terminológico, aproveito para diferenciar dois termos que serão abundantemente utilizados no decorrer dessa pesquisa: ouvir e escutar. Ainda que muitas vezes aplicados como simples referência ao ato de se receber e processar estímulos sonoros, faz-se necessário um amparo conceitual para que, nos momentos oportunos, consigamos diferenciá-los para os devidos fins. Para isto, a distinção conceitual dos termos será aqui aplicada de acordo com a proposta do filósofo e sociólogo francês Roland Barthes:

Ouvir é um fenômeno fisiológico; escutar é um ato psicológico. É possível descrever as condições físicas da audição (os seus mecanismos), pelo recurso à acústica e à fisiologia do ouvido. Mas a escuta não pode definir-se senão pelo seu objeto, ou, se preferirmos, pelo seu desígnio. (1990: 217)

\subsection{Tipos de escuta - de Adorno a Stockfelt: convergências e divergências}

Aqueles que costumam frequentar salas de concertos já devem ter notado que existe uma regra de comportamento implícita vigente nesses ambientes, a qual se baseia na intolerância a ruídos - mesmo discretos - que venham a interferir na apreciação plena das obras executadas. Tosses, poltronas, sussurros e o virar das páginas dos librettos não são bemvindos ${ }^{6}$. Ainda habita nos corredores das salas de concerto uma atmosfera de vigilância constante, e uma iminente punição àquele que produzir ruídos indesejados ou ameaçadores durante a execução de uma obra.

\footnotetext{
${ }^{6}$ A esses ruídos foi dado um sentido completamente novo na obra 4'33”, de John Cage (1952), na qual eles constituíam não uma interferência indesejada, mas o próprio material sonoro da obra; em outras palavras, constituíam eles a obra em si.
} 
Essa tradição, por mais respeitosa que seja com os compositores e intérpretes, não deixa de sugerir uma questionável supervalorização da audição, em algum grau desvinculando-a da experiência multissensorial discutida por Iazzetta (2009). Exigindo receber a atenção integral e concentração exclusiva dos ouvintes, essa tradição pode inclusive vir a prejudicar a própria experiência musical da escuta, uma vez que permeia de regras uma interação que naturalmente transcende apenas o sentido da audição e visão dos intérpretes por parte do ouvinte.

A ênfase em uma escuta concentrada e racional, bastante apoiada nas tradições comportamentais exigidas em um concerto de música erudita, acabou por categorizá-la como uma escuta mais qualificada. Em outras palavras, tiraria maior proveito da escuta aquele que fosse capaz de perceber os mínimos detalhes da obra escutada, e que não deixasse passar sequer uma nota sem compreendê-la. O sociólogo Theodor Adorno ((1973) 2011) traduz esta escuta minuciosa e consciente como uma escuta estrutural, sendo esta de alguma forma superior a outras práticas de escuta ${ }^{7}$. Assim define o autor a escuta estrutural:

Ele (o ouvinte) seria plenamente consciente, ao qual, a princípio, nada escapa e que, ao mesmo tempo, presta contas daquilo que escuta. Aquele que, digamos, ao se confrontar com uma peça dissolvida e avessa a anteparos arquitetônicos tangíveis, como, por exemplo, o segundo movimento do Trio para Cordas de Webern, soubesse nomear suas partes formais, este bastaria, de saída, para construir tal tipo. (2011: 60)

E prossegue descrevendo o processo de assimilação do ouvinte:

Ao seguir espontaneamente o curso de uma música intrincada, ele escuta a sequência de instantes passados, presentes e futuros de modo tão contíguo que uma interconexão de sentido se cristaliza. Ele apreende distintamente até mesmo os elementos intrincados da simultaneidade, como a harmonia e da polifonia. O comportamento completamente adequado poderia ser caracterizado como escuta estrutural. (2011: 60)

Vai ainda além, definindo uma tipologia de ouvintes e os classificando de acordo com a maneira com que se comportam e compreendem a música a que estão expostos. Para Adorno, o ouvinte expert é aquele que possui uma escuta perfeitamente adequada. Este é plenamente consciente e atento a tudo o que chega a seus ouvidos. Durante todo o processo de escuta é capaz de compreender o desenvolvimento que sucede de uma maneira racional, sempre amparado pela técnica. É o ouvinte capaz de concretizar a escuta estrutural. E este, de

\footnotetext{
${ }^{7}$ Na obra Introdução à Sociologia da Música, de 1973. Na edição brasileira de 2011, a descrição encontra-se nas páginas 60-61.
} 
acordo com o autor, é peça rara de se encontrar, até mesmo em meio a músicos profissionais (2011: 61). Talvez por isso Adorno defenda que a escuta jamais seja realizada apenas como um simples acompanhamento de outras atividades (2011).

Ao classificar os ouvintes, Adorno propõe que do lado oposto da tabela - e ao ouvinte expert - estaria o ouvinte incapaz de compreender a música e apreciá-la como arte: o ouvinte do entretenimento. Esse seria, "do ponto de vista quantitativo, o mais substancial dentre todos os tipos" (2011: 75), escutando música apenas como entretenimento, e nada mais. Para Adorno, “[...] o ouvinte do entretenimento é aquele pelo qual se calibra a indústria cultural” (idem). Ou seja, e melhor dizendo, ele não só escuta música apenas como entretenimento, mas a consome pelos mesmos fins.

No entanto, o exigente modelo de escuta estrutural adorniano foi posto em xeque por diversos autores, entre eles Peter Szendy (2008), Barry Truax (2001) e Rose Subotnik (1988). É sobre estas teorias que discorreremos a seguir.

\section{Rose Subotnik e a desconstrução do modelo adorniano}

A musicóloga americana Rose Subotnik (1988; 1996), discordando de Adorno em pontos relacionados à escuta estrutural, aponta algumas lacunas e possíveis problemas nas reflexões do sociólogo acerca dessa prática de escuta. Descrevendo ela mesma a escuta estrutural como "[...] uma escuta ativa que, quando realizada com sucesso dá ao ouvinte a impressão de estar compondo a música enquanto esta toca, em tempo real” (1996: 150), aponta então alguns pontos que julga questionáveis.

O primeiro, segundo a concepção de Subotnik em relação ao sociólogo, é o de que, para este, o valor estrutural e moral são sinônimos, o que leva o sociólogo a uma rejeição de repertórios julgados como "moralmente ofensivos". Ou seja, o valor moral de uma obra estaria atrelado em algum nível à complexidade da estrutura musical da obra, daí justificando o grande apreço de Adorno pela música erudita (música séria), e sua crítica a outros gêneros tidos por ele como menos complexos (música ligeira), consequentemente reduzindo o valor moral de tais obras. O ouvinte então capaz de compreender a estrutura de uma obra acaba por libertar o significado dessa mesma da distorção e da manipulação social.

O segundo se dá justamente frente à valorização da estrutura musical de uma obra. De acordo com Subotnik (1996), para que se exista uma escuta estrutural primeiro se deve ter uma obra estruturalmente impecável. Estendendo sua crítica a Schoenberg, ela afirma que a 
mesma rigidez exigida do ouvinte é, antes, exigida do compositor, citando o compositor alemão como exemplo. Subotnik aponta que, para Schoenberg, “[...] a sensação emocional mais profunda na música é obtida precisamente através de uma intensa integridade estrutural da mesma" (1996: 155).

Outra crítica se dá pelo viés cultural. Subotnik percebe uma lacuna na limitação do repertório discutido por Adorno, afirmando que não seria possível que um ouvinte compreendesse na totalidade exigida todos os repertórios, mesmo se restritos à cultura ocidental. Assim, o ouvinte parece obter melhores resultados quando aplica sua escuta ao “repertório comum”, ou seja, “de Corelli a Mahler” (1996: 157).

A musicóloga também descreve o modelo adorniano como uma escuta limitadora, primeiro por contribuir para a divisão de gêneros, e depois por "fechar" o ouvinte nos estilos tidos como superiores. O problema, nesse segundo caso, seria que esse modelo desencorajaria uma apreciação musical livre; open-ended, de certas músicas, julgando-as a partir de sua capacidade de se auto-justificar, distanciando-nos assim das obras desprovidas dessa preocupação. E finaliza:

O ideal da escuta estrutural tem feito nossa percepção e nossas preocupações analíticas, enquanto musicólogos quase completamente dependentes de partituras, como se essas fossem livros. Alguém pode até ser tentado a argumentar se a escuta estrutural faz mais uso dos olhos do que dos ouvidos... (1996: 161)

\section{Szendy, Truax e a escuta distraída}

A rotina do cidadão metropolitano do século XXI geralmente é repleta de atividades a serem executadas em um curto espaço de tempo. Com isso, o hábito de dedicar um tempo do dia exclusivamente para a escuta musical foi tornando-se pouco a pouco mais inviável, ou improvável, de se acontecer. Especialmente após o advento das mídias portáteis, o cidadão se tornou capaz de associar a escuta a outras atividades concomitantes. Essa escuta, porém, não atenderia as exigências da escuta estrutural, visto que a atenção do ouvinte estaria sendo dividida com outra atividade, muitas vezes de importância primária.

O filósofo e musicólogo francês Peter Szendy (2008) questiona a rigidez da escuta estrutural, bem como seu possível efeito na perda da espontaneidade da própria escuta, defendendo a chamada escuta distraída. Szendy questiona: "Uma certa distração não seria também condição necessária para uma escuta ativa tanto quanto os detalhes para uma escuta 
funcional e estrutural?" (SZENDY, 2008: 128). E segue defendendo a espontaneidade do ouvir:

Os ouvintes "distraídos" são sempre e necessariamente surdos, musicalmente falando? Não existe também uma parcela de surdez (talvez maior do que imaginamos) na plenitude, e até mesmo na totalidade proposta pela escuta estrutural? (2008: 119)

A escuta musical dos séculos XX e XXI devem ser analisadas sempre contextualmente, em especial se o ambiente observado for o urbano. Nesse caso, é de suma relevância apropriar-se da realidade móvel da sociedade urbana a fim de se compreender os comportamentos associados à escuta. Em uma sociedade movida pelo fluxo de informações e pela mobilidade, é natural se esperar hábitos de escuta musical de caráter semelhante. A música, então, em muitas ocasiões deixa de ser a atividade primária ao longo das jornadas dos cidadãos. A atenção do ouvinte é segmentada entre estações de trens, horários, monitoramento de sua segurança nas ruas, telefonemas, atividades domésticas, trânsito, trabalho e afins. E em todas essas atividades ele pode estar acompanhado de um aparato portátil com músicas sendo projetadas dentro de seus ouvidos.

Exigir desse ouvinte a atenção integral para a obra em um nível estrutural seria desleal; seria propor sua retirada momentânea do fluxo de atividades às quais ele está engajado para uma reconfiguração do foco de sua atenção exclusivamente à música, ação que ele pode ser inclusive incapaz de realizar, visto que pode não haver - e normalmente não há nesse período de atividades diárias, a pré-disposição, ou o interesse por uma escuta estrutural. Em outras palavras, devemos compreender que existem intenções, sob o total domínio do ouvinte, acerca de suas experiências de escuta, de maneira que ele intencionalmente venha a optar por uma apreciação estrutural e centrada ou por uma experiência de entretenimento, secundária.

Para Szendy (2008) a escuta distraída seria essa forma de se ouvir, na qual o ouvinte está engajado em outra atividade primária, com apenas parte de sua atenção voltada para a música, e ainda assim, provavelmente sem o interesse ou as condições de analisá-la de maneira mais minuciosa.

O compositor canadense Barry Truax (2001) contribui apontando a diferença entra uma escuta analítica e uma escuta distraída. Para o autor, durante a primeira se vasculha o som minuciosamente em busca de informações, enquanto na segunda o ouvinte está engajado em outra atividade não-musical de caráter prioritário (2001: 163). 
Adorno, por sua vez, se declara radicalmente contrário à escuta distraída, relacionando-a com a prática do ouvinte de entretenimento, ou seja, àquele incapaz de saborear a música em sua plenitude, estabelecendo com ela uma relação normalmente passiva, superficial e massificada:

O caráter de compromisso não poderia mostrar-se de forma mais drástica do que naquele comportamento que deixa o rádio ligado enquanto, ao mesmo tempo, põe-se a trabalhar. Em termos históricos, essa atitude desconcentrada está, desde há muito, preparada pelo ouvinte do entretenimento, sendo, de resto, sustentada de diversas maneiras pelo material relativo a tal escuta. (2011: 77)

\section{Stockfelt e a escuta contextual ${ }^{8}$}

Enquanto Adorno (2011) advoga pela escuta estrutural, e Szendy (2008) pela escuta distraída, Ola Stockfelt (2004) traz à tona na obra Adequate Modes of Listening (2004) uma mais moderada perspectiva de escuta. Enquanto o julgamento do tipo mais apropriado de escuta parece fugir de seu escopo, o autor propõe que a escuta está diretamente ligada ao contexto em que ocorre. Assim, “[...] os mesmos ouvintes têm a competência de usar o mesmo tipo de música, ou até a mesma música, em uma variedade de formas diferentes em situações diferentes" (STOCKFELT, 2004: 89). Ou seja, a mesma sinfonia que acalma determinado ouvinte antes de dormir, pode irritar os ouvintes adolescentes de um shopping center, ou se tornar uma ameaça na estrada quando escutada pelo motorista atento às suas melodias. Não se trata, então, de uma forma de escutar prefixada e pré-estabelecida como estrutural ou distraída, mas de uma escuta variante, que necessariamente está vinculada ao contexto em que ocorre, "[...] conferindo a cada obra um estado de fluxo e mobilidade" (IAZZETTA, 2009: 40).

A escuta contextual será analisada com mais ênfase posteriormente, ao tratarmos das formas do ouvinte contemporâneo interagir com sua música e com o ambiente externo.

\subsection{A música mecanizada e a escuta mediada}

\footnotetext{
${ }^{8}$ O temo escuta contextual não foi formalmente proposto por Ola Stockfelt, mas proposto pelo autor desse trabalho como maneira de definir e diferenciar esse tipo de escuta das demais.
} 
Entre as inovações tecnológicas da transição do século XIX para o século XX, podemos iniciar destacando o fonógrafo, em 1877 - ano em que Thomas Edison recebeu a patente do aparelho. Ao contrário do período anterior, em que a escuta dependia da presença física do intérprete, agora a máquina se apresenta como mediadora deste processo, de maneira que agora o ouvinte já conseguia escutar uma orquestra dentro da sala de sua casa, ou ainda um concerto particular de seu cantor predileto dentro de seu quarto.

Este grande feito para admiradores da música demandou uma adaptação do modo de se escutar, e essa adaptação não foi súbita. Gradativamente, os ouvintes precisaram se acostumar a uma escuta não mais estritamente ligada à presença física do intérprete, e à possibilidade de se ouvir música como e onde desejassem, sem a dependência de eventos e ocasiões outras que propiciassem essa experiência.

A este contexto da música mediada tecnologicamente e ao som separado de sua fonte sonora é que o pesquisador canadense Murray Schafer (1992) aplica o termo esquizofonia. Ao descrever o impacto do surgimento dos equipamentos eletrônicos de transmissão e sua inserção no cotidiano da sociedade, afirma Schafer:

Agora tudo isso se modificou. Desde a invenção dos equipamentos eletrônicos de transmissão e estocagem de sons, qualquer som natural, não importa quão pequeno seja, pode ser expedido e propagado ao redor do mundo, ou empacotado em fita ou disco, para as gerações do futuro. Separamos o som da fonte que o produz. A essa dissociação é que chamo esquizofonia, e se uso, para o som, uma palavra próxima de esquizofrenia é porque quero sugerir a você o mesmo sentido de aberração e drama que esta palavra evoca, pois os desenvolvimentos que estamos falando têm provocado profundos efeitos em nossas vidas. (1992: 172)

De fato os aparelhos eletrônicos de transmissão afetaram o modo de se ouvir e os costumes sociais:

[...] agora o som de grandes orquestras operísticas pode caber em uma prancha de windsurf, e o som de um violão de nylon pode preencher um estádio de futebol inteiro; pode-se ouvir uma marcha na banheira de hidromassagem e músicas do estilo salon nas montanhas. (STOCKFELT, 2004: 90)

Discutindo sobre essa mediação, Béla Bartók (1985) aponta algumas de suas insatisfações com a música mecanizada - termo utilizado por ele para definir a música mediada tecnologicamente, diferenciando-a da música "natural", ou seja, não-mediada. Sobre esta nova forma de se produzir e escutar música, afirma, em palestra proferida em 1937:

Quanto à música mecanizada, esta é minha opinião: cada um dos sons, o dinamismo, os timbres e todas as demais nuançes da música 'natural' são tão complicadas que, por enquanto, produzir algo 
parecido com eles através de meios mecânicos resulta-se tão impossível como a criação artificial de um organismo vivo. [...] A incisão em discos é para a música original o que a conserva em latas é para a fruta fresca: nesta existe vitaminas, enquanto na outra não. (BARTÓK, 1985: 234)

Para Bartók o som gravado perde sua naturalidade, tornando-se artificial e distanciando-o da experiência real da escuta.

O compositor Igor Stravinsky (1962) também questiona alguns aspectos da música mecanizada, defendendo que a mediação tecnológica interfere de maneira degradante no aprendizado musical. Para ele, a música gravada tende a desmotivar todo e qualquer esforço por parte do estudante, que ao invés de agente ativo no ato de "buscar a música" literalmente caminhar até o professor, ou fonte musical a ser estudada - se acomoda, tornando-se passivo diante da facilidade de ter a música caminhando em sua direção, a apenas um botão de distância.

\section{O rádio e a inauguração da escuta itinerante}

A partir do fonógrafo, às mídias de reprodução sonora foram incorporadas inovações tecnológicas visando a praticidade e a ampliação de seu campo de atuação. Tomemos como exemplo o rádio. De acordo com Iazzetta (2003), assim como o fonógrafo nas décadas de 1920 e 1930 e posteriormente os sistemas em alta fidelidade (hi-fi), nas décadas de 1960 e 1970, o rádio foi amplamente associado à modernidade nas décadas de 1920 e 1930, sendo visto como um símbolo de uma nova era tecnológica e de progresso. Em 1920 acontece o primeiro concerto em radiodifusão do mundo em Chelmsford, na Inglaterra, e em 1922 a indústria americana registra uma explosão de popularidade da indústria radiofônica.

Gradativamente o rádio se estabeleceu como um poderoso agente formador de hábitos de escuta. Uso aqui o termo formador porque, a partir do momento em que uma só pessoa (ou um grupo seleto) elege o material sonoro que chegará às casas e carros de milhares de outros indivíduos, necessariamente um repertório de milhões de música é reduzido a algumas dezenas ou centenas que veicularão diariamente, por vezes nos mesmos horários, determinando assim o que será ouvido e quando será ouvido. Menezes (2007) reflete sobre o papel do rádio enquanto elemento articulador de tempo nas metrópoles, como meio de se estabelecer vínculos que promovem a organização da vida social no meio urbano. 
Um fator particularmente poderoso e inédito foi introduzido pelo rádio na metade do século XX: a portabilidade. Muitas décadas antes da internet, a disseminação do rádio a pilha possibilitou um novo hábito de escuta, no qual os ouvintes poderiam, pela primeira vez na história, carregar seu aparelho portátil consigo nos bolsos, ouvindo as músicas (inclusive de outros países) através de ondas $A M$. Novamente a escuta precisou ser reaprendida, pois da mesma forma com que através do fonógrafo os ouvintes precisaram se acostumar a ouvir música em casa sem a presença dos músicos, agora os ouvintes precisaram se acostumar com a possibilidade de escutar música - e mais que isso, carregá-la consigo - enquanto caminhavam ou dirigiam.

No final do século $\mathrm{XX}$, com o advento das mídias portáteis (iPod, tablets $e$ smartphones) a escuta inovou sua maneira de ser móvel, mais uma vez requerendo aos ouvintes um novo processo de adaptação, o que, a propósito, eles parecem o fazer sem muito esforço.

As mídias portáteis do século XXI permitem ao usuário carregar suas playlists para qualquer lugar, criando-se uma escuta também itinerária. Ao longo de sua jornada cotidiana o ouvinte passa por metrôs, ônibus e caminha, habitando da sala de espera do dentista à sala de aula. Participa de paisagens sonoras distintas e se confronta com centenas de sons ao longo de seu percurso. Em seu aparelho de reprodução portátil, o mesmo aconteceu. Dezenas de músicas, por vezes completamente distintas umas das outras, acompanharam o trajeto. Relembremos a teoria de Stockfelt (2004) para uma situação hipotética:

Suponhamos que haja, na playlist do ouvinte em questão, uma música em especial que este aprecie, e que seja escutada por duas vezes consecutivas. Na primeira vez que a faixa é executada o ouvinte se situa dentro de um metrô, rodeado de centenas de pessoas conversando entre si, e com os sons do próprio metrô como trilha de fundo. Na repetição da faixa, esse ouvinte já se ausentou do metrô, e agora se encontra em uma sala de espera de um consultório médico, sozinho e em silêncio. Não estaria o contexto diretamente ligado à experiência musical da escuta desse indivíduo?

As mídias portáteis se desenvolveram a partir da emergente necessidade (ou não) de se ter acesso a tudo o que se deseja na menor fração de tempo possível. Não sabemos a hora em que precisaremos de uma informação, de um arquivo ou de um telefonema. Seria prudente, então, carregar no bolso um objeto que nos permita acesso a tudo na hora que desejarmos.

Devemos perguntar, portanto, se diante da possibilidade do tudo não temos tido dificuldade em escolher o pouco, o óbvio. Tamanha é a sede de um leque de opções infinito, que o ouvinte se arrisca a gastar mais tempo à procura da música desejada em centenas de 
pastas e subpastas do que a escutando. Diante de ouvintes com tantas possibilidades de escuta, transitando por ambientes tão distintos quase que simultaneamente, é natural que a escuta também tome características transitórias.

A capacidade de escuta torna-se, nesse contexto, também volátil. Ora o ouvinte se atentará aos elementos específicos da música; ora não escutará sequer a voz do cantor, devido aos exageros da paisagem sonora externa do momento - de acordo com Schafer (1997), lo-fi ${ }^{9}$. Nesses casos, deve-se considerar a possibilidade de uma escuta um tanto distorcida, em virtude da compensação contra os estímulos externos.

Consideremos o parâmetro musical da dinâmica: no caso de um ouvinte selecionar uma sinfonia cujo início seja em pianíssimo, este não será capaz de seguir a música estando dentro de um ônibus em horário de rush. Ao aumentar o volume (intensidade), indiretamente transforma o pianíssimo em mezzoforte. Poucos segundos após seu início, a sinfonia então apresenta uma cadência em fortíssimo. O susto fará o ouvinte automaticamente reduzir o volume, e o fortíssimo será transformado novamente em mezzoforte. Neste contexto, a estrutura e o sentido da obra foram completamente alterados, dificultando em graus extremos a prática de uma escuta estrutural.

\section{Estudo de caso: Modelos e hábitos de escuta radiofônica no cotidiano dos imigrantes italianos do interior de São Paulo}

A fim de adentrarmos de maneira ainda mais minuciosa no contexto histórico da escuta radiofônica, tomemos como estudo de caso o papel do rádio durante o processo de colonização do interior paulista a partir da chegada dos imigrantes italianos.

Um processo de imigração, pela sua própria natureza, gera impactos tanto no imigrante quanto no espaço a ser habitado. Parte majoritária desse impacto é de natureza cultural. $\mathrm{O}$ imigrante traz uma bagagem cultural diferente da encontrada nas terras em que chega, iniciando neste espaço um processo de duas vias: a implantação de novas tradições e práticas culturais, e a apreensão destes mesmos aspectos já existentes na região habitada. Essas vias então se convergem em uma via de mão única: a da adaptação, ou como veremos a

\footnotetext{
${ }^{9}$ De acordo com o pesquisador Murray Schafer, há diferença entre os dois sistemas (hi-fi e lo-fi). O autor assim explica: "Um sistema $h i$ - $f i$ é aquele que possui uma razão/sinal favorável. A paisagem sonora $h i-f i$ é aquela em que os sons separados podem ser claramente ouvidos em questão do baixo nível ambiental. [...] Em uma paisagem sonora $l o-f i$ os sinais acústicos individuais são obscurecidos em uma população de sons superdensa." (SCHAFER, 1997: 71-72)
} 
seguir, aculturação. Duas realidades distintas que passarão pelo processo da convivência mútua, integral e duradoura, visto que após essa fusão se torna praticamente impossível que uma comunidade volte a ser como era antes, abandonando completamente os hábitos previamente adquiridos. A psicóloga social e psicoterapeuta intercultural Sylvia DeBiaggi assim descreve a complexidade deste processo:

Nesses encontros/desencontros culturais é toda a articulação do
sentido da vida que é posta em xeque, levando a complexos processos
de manutenção, de rejeição, e de negociação relativos a valores,
relações familiares, identidade pessoal e grupal, educação dos filhos,
hábitos alimentares, enfim a toda a realidade humana. (DEBIAGGI,
PAIVA, 2004: 10)

A mesma autora ainda faz uso de um termo que a própria psicologia, juntamente com a antropologia, tem utilizado para descrever o conjunto desse processo: aculturação, termo este que bem define a miscigenação cultural a que os povos se sujeitam ao lidarem com processos migratórios.

É natural que o imigrante traga consigo parte de sua cultura, e é compreensível que a vivência de suas origens ajude nesse árduo processo de adaptação. Por esta razão é que facilmente encontramos, no caso de uma metrópole, bairros caracterizados pela cultura dos imigrantes que ali habitaram, como, por exemplo, uma grande concentração de restaurantes de cozinha italiana em uma região previamente colonizada por italianos, ou ainda eventos culturais e festividades orientais em um bairro colonizado por japoneses. A capital paulista é um bom exemplo, nesse sentido. Em outras palavras, não só essa bagagem trazida colabora para um desenvolvimento cultural da região, mas também se faz importante para o próprio imigrante que, através dela, consegue se sentir "em casa" mesmo estando a milhares de quilômetros de sua terra natal, como de fato ocorreu com os imigrantes italianos deste estudo de caso específico.

Partindo desse contexto, entende-se a relevância do rádio enquanto ferramenta agregadora de cultura, uma vez que este funcionou como contato direto entre os dois lados do oceano. Através do rádio os italianos recém-chegados da Europa mantinham vivo o elo entre sua cultura natal e a "nova cultura" regional brasileira: noticiários, músicas e qualquer outro tipo de informação ou entretenimento originado no além-mar.

O especialista em ópera Sergio Casoy, nascido em 1949, que já foi residente no Brás (capital) relata, em entrevista, a lembrança do hábito de vizinhas que compravam tomate na feira e os colocavam em grandes tábuas que se usava para coarar. Colocavam também fatias de tomate com sal no sol para secar. O tomate seco ia para garrafas de vinho ou champanhe 
arrolhadas, ou então sotto oleo. E sempre nesses momentos, em que alguma italiana estava em casa ou alguém ensinando a fazer comida, o rádio estava ligado "a todo vapor" tocando música italiana daqueles anos (CASOY, 2013).

Neste contexto cotidiano, referente à primeira metade do século $\mathrm{XX}$, poderíamos identificar um modelo de escuta e um hábito de escuta. Era comum, de acordo com o relato de Casoy, as mulheres cozinharem e cortarem tomates ao som de música italiana. Podemos imaginar, ou ao menos pressupor, que também conversavam entre si quando duas ou mais estavam presentes. Algumas questões então vêm à tona: Que músicas eram essas? Em que volume (nível de intensidade) eram escutadas? Por que o rádio era ligado ao cozinhar? Em suma, qual era o papel dessa música ali escutada?

Ainda que seja difícil precisar essas respostas algumas décadas depois dos fatos, ao menos uma coisa é certa: os modelos e hábitos de escuta eram ali exercidos dentro de um contexto não somente musical, mas também cultural e social. A música, mais do que som de fundo, fazia emergir aspectos culturais enraizados na memória de vida cozinheira, de alguma forma influenciando no resultado final de sua atividade.

Será que estes tomates seriam preparados exatamente da mesma forma, incluindo seu sabor final, na ausência do rádio e das canções italianas? Penso que não. A música é capaz de interagir com inúmeras faculdades emocionais e intelectuais do ser humano, podendo inclusive interferir no estado de espírito do ouvinte ${ }^{10}$, sendo muito pouco provável que, ao se expor a um estímulo musical durante algum período de tempo, alguém passe de forma completamente neutra a ele. Normalmente alguma reação, física ou emocional, é esboçada, seja no tamborilar dos dedos frente a um ritmo agitado ou a um relaxamento quase inconsciente ao som de uma trilha sonora de uma loja de essências aromáticas. Sob este foco, pode-se pensar que o tomate cortado e a comida cozinhada por uma imigrante italiana ao som de música italiana em São Paulo é único, e que a escuta exerceu, naquele momento, um papel agregador de valores culturais. Enquanto modelo de escuta, poderíamos facilmente reconhecer nessa cozinha o modelo proposto por Peter Szendy (2008), da escuta distraída, uma vez que a música não era o foco principal da atenção da cozinheira, envolvida primariamente em outra atividade.

Relatos de uma época

\footnotetext{
${ }^{10}$ Como será discutido no Capítulo 4, desse trabalho.
} 
A fim de poder explicitar de maneira fiel o cotidiano, bem como os hábitos de escuta, de algumas comunidades de imigrantes italianos residentes no interior de São Paulo na primeira metade do século XX, busquei relatos de pessoas que viveram nessa época e nesses lugares, - nesse caso avós do autor, ambas filhas de imigrantes - que pudessem colaborar com este trabalho. São elas Thereza Guidoni da Silva e Leadyr Noé dos Santos.

Thereza Guidoni, nascida em 1934 na cidade de Sales de Oliveira, interior de São Paulo, relata alguns hábitos de escuta vividos durante o período da II Guerra Mundial:

\begin{abstract}
Não tínhamos rádio em casa. Era caro, e poucas pessoas no bairro possuíam um. Meu pai era dono de um bar, e no bar ele tinha um rádio. Todos os dias muita gente vinha ali não só para comprar bebidas, mas também para conversar. E ali essas pessoas ficavam, e às vezes passavam horas conversando e ouvindo o rádio do meu pai. [...] Todos queriam ouvir as notícias da guerra. Naquele tempo não era tão fácil usar o telefone como é agora. Em frente ao bar havia a central telefônica da cidade. Quando queríamos ligar para alguém, ligávamos na central e falávamos: 'Por favor, eu gostaria de falar na casa da Dona Amélia.' A telefonista então transferia a ligação para a casa da Dona Amélia, que ficava a uma ou duas quadras de distância (risos). Após alguns minutos ligávamos novamente: 'Por favor, você poderia transferir para a casa do Seu João?', e a ligação era então transferida para a casa do Seu João. E assim por diante...
\end{abstract}

A memorialista relembra, ainda, os tempos em que o Brasil declarou guerra às Potências do Eixo:

Nos tempos de guerra, todos queriam saber o que estava acontecendo nos outros países, principalmente na Itália, que era de onde meu pai tinha vindo. Como minha casa ficava próxima ao trilho do trem, às vezes eu era acordada com o barulho do trem passando. Eu e minhas amigas íamos correndo para fora de casa, e víamos aquele trem, cheio de expedicionários indo para a guerra, alguns inclusive se despedindo e acenando com as mãos para suas famílias. Toda essa curiosidade era matada (sic) pelo rádio do bar do meu pai. Até que um dia o delegado confiscou o rádio. Passaram não só no bar, mas em vários outros estabelecimentos da rua levando os rádios embora. Eles simplesmente entraram e disseram que aquilo era perigoso, e que nós não iríamos mais receber as notícias da guerra e do que estava acontecendo mundo afora. (SILVA, 2013)

Para o comunicador e radialista argentino Mario Kaplún (1978), o rádio possui três funções fundamentais: informar, entreter e educar (formar cidadãos), funcionando de forma a “[...] elevar o nível de consciência, estimular a reflexão e converter cada homem em um agente ativo da transformação do seu meio natural, econômico e social" (1978: 21). Claramente se percebe no relato acima que o rádio era não somente um elemento formador e informador, mas um ponto de encontro, de convívio social. Ao redor do rádio se socializava. 
Ali os filhos, netos e esposas ansiavam por informações a respeito daqueles que pegavam os trens, e até mesmo dos que jamais pisaram no Brasil, mas que residiam em países em guerra. A escuta, ora distraída e ora atenta, novamente se situava em meio a um contexto social e cultural, ao redor de uma mídia que posteriormente se tornaria muito mais difícil de ser confiscada, se tornando portátil no formato do rádio à pilha.

Outra recordação, relatada pela senhora Leadyr Noé dos Santos (77 anos), mostra um hábito de escuta do cotidiano familiar também durante o período da II Guerra Mundial:

$\mathrm{Na}$ casa de meu pai a gente tinha um rádio grande na sala. Às vezes a gente ficava brincando, eu e minhas irmãs, correndo para lá e para cá na casa, e o rádio tocando. Meu pai ficava fazendo suas coisas com o rádio ligado. Às vezes ele prestava mais atenção e às vezes parecia que ele não estava nem aí para o rádio. Mas ele ficava lá, tocando. Mas quando começava o programa do Repórter Esso, a gente parava tudo o que estava fazendo e vinha correndo para a sala, porque a gente sabia que alguma coisa importante tinha acontecido. Era a gente ouvir aquela musiquinha do começo do programa (a entrevistada cantarolou a vinheta de abertura) que todo mundo vinha para a sala. Meu pai parava o que quer que estivesse fazendo, e todos nós ficávamos ali parados, ouvindo o que o Repórter Esso ia dizer. Meu pai devia estar esperando notícias da Itália... [...] Quando acabava o programa a gente voltava a fazer o que a gente estava fazendo, e voltava a correr pela casa, e meu pai a terminar o que ele estava fazendo (SANTOS, 2013)

Podemos identificar nesse relato múltiplos modelos de escuta atuando quase simultaneamente. Primeiro, a escuta distraída, nos momentos em que o rádio era simplesmente um som ambiente, ora notado ora ignorado. Subitamente, ao som da vinheta de abertura do programa Repórter Esso, os ouvidos se atentavam, e essa escuta, até então em segundo plano, se tornava o foco principal de toda atenção, e cada palavra era minuciosamente processada e compreendida, o que nos remete ao modelo de escuta adorniano da escuta estrutural. Com a mesma velocidade com que se instituiu, essa escuta era descontruída ao final do programa, em que o rádio voltava a ser o "som ambiente". Novamente nota-se o rádio como mídia agregadora e (in)formadora, e o reunir-se ao redor dele caracterizava-se como um dos hábitos de escuta da época.

\section{As duas vias do rádio}

Esses breves relatos explicitam-nos como a escuta sobrepõe-se ao simples "processar sons involuntariamente no cérebro". Ao definir hábitos, juntamente com o progressivo avanço tecnológico das mídias de produção e reprodução sonora, a escuta se eleva a um patamar não só multissensorial, mas também multifacetado enquanto prática musical, histórica e social. 
O rádio, no entanto, não se limitou a ser apenas um veículo agregador de culturas, com a função de minimizar o choque cultural dos imigrantes. Após a instalação definitiva desses imigrantes, o rádio adquiriu uma nova função: a de difundir essa cultura (em grande parte musical) nas terras recém-habitadas.

Na obra Vissi d'Arte: por amor a uma profissão, Juliana Coli (2006), cantora lírica e socióloga, enfatiza que a música é uma das grandes tradições culturais da Itália. Muito antes do Brasil ser descoberto, já no século VI, o Papa Gregório I difundia o Canto Gregoriano, a partir da Igreja Católica, para todo o ocidente. Pouco mais de um século após a descoberta do Brasil, a Itália já vagava no Período Barroco, enriquecendo as tradições musicais com a produção e divulgação musical ali realizada. A ópera, por exemplo, no ano de 1636, em Veneza, pela primeira vez "se torna um produto comercial, através de aquisição do bilhete e com a presença de público vasto e em grande local" (2006: 62). Percebe-se que com tão grande tradição musical, seria inconcebível que os imigrantes italianos não contagiassem o interior paulista com sua musicalidade enraizada em suas entranhas culturais. E, graças ao rádio, o fizeram de forma maneira bastante intensa e eficaz.

Os cantores e canções italianas foram gradativamente ganhando destaque também em rádios locais, e uma geração de filhos de imigrantes italianos já se sentia suficientemente ambientada no Brasil a ponto de se utilizarem de sua bagagem cultural para fundarem suas carreiras. O grande nome do samba João Rubinato, conhecido popularmente como Adoniran Barbosa, era filho de imigrantes italianos desembarcados no Brasil na entrada do século XX. Ironicamente, o sangue italiano de Adoniran, bem como a cultura musical engendrada em sua bagagem, os levaram a se tornar uma das maiores referências do samba, gênero genuinamente brasileiro.

Mas não somente Adoniran Barbosa cresceu com a influência das canções italianas do rádio, mas após o início de sua carreira, foi através do rádio que sua música se disseminou. $\mathrm{A}$ mesma ferramenta de formação se transmudou em ferramenta de disseminação cultural, e agora os rádios que antes reproduziam músicas legítimas italianas incluíam em seus repertórios músicas produzidas por descendentes italianos, sendo essas canções, como no caso de Adoniran, uma nova trilha sonora dos redutos de encontro paulistas.

Os hábitos de escuta são extremamente maleáveis, e se moldam conforme inúmeros fatores que vão desde o desenvolvimento de novas mídias portáteis até novos comportamentos e tendências sociais de massa. As variantes da escuta refletem muito mais que um gosto musical, e a música que sai dos falantes de um rádio ou de um iPod revela muito mais do que frequências sonoras aguardando por entrarem na rota de um ouvinte. 
Podem revelar formas de comportamento, idiossincrasias e costumes de uma sociedade que corre o risco de simultaneamente se encontrar tão imersa no universo sonoro e, ao mesmo tempo, tão surda para os significados desses sons.

\subsection{Os predecessores das mídias portáteis e a influência cultural}

Nas últimas décadas as tecnologias associadas à gravação e reprodução sonora têm evoluído exponencialmente em cada vez mais curtos períodos de tempo. Tal avanço permite até especulações acerca do fato das empresas dominantes nesse mercado disponibilizarem um produto já possuindo em mãos uma tecnologia superior, que poderá vir a ser lançada alguns meses depois, dependendo da aceitação do artefato pelo público-alvo. E assim sucessivas séries de aparatos são sobrepostas umas às outras sem que necessariamente apresentem melhorias significativas ou relevantes sobre a anterior. Até mesmo a nomenclatura de alguns aparelhos soa intencionalmente "neutra", na intenção de sugerir ao consumidor que o aparelho é novo, mas parecido com o anterior, ou seja, pelo nome se percebe que houve alguma melhoria, porém muitas vezes nem mesmo o consumidor sabe exatamente qual.

Ilustrando esse fluxo de inovações, tomemos como exemplo um dos gadjets de maior popularidade e venda no ranking mundial: o iPhone.

Em junho de 2007 a Apple lançou oficialmente no mercado seu primeiro smartphone, o iPhone 3G, descontinuado a partir do final de 2008 devido à chegada de seu sucessor, o iPhone 3GS em junho de 2009. Em junho de 2010 foi apresentado o iPhone 4 em substituição à série 3GS. Em outubro de 2011 foi então lançado o iPhone 4S, tendo sido substituído pelo iPhone 5 em setembro de 2012. Em setembro de 2013 foram então introduzidos o iPhone 5C e o iPhone 5S, que são praticamente o mesmo aparelho, com o principal diferencial de a versão $5 \mathrm{~S}$ possuir um recurso chamado Touch $I D$, que permite a autenticação para uso do aparelho através de impressão digital ${ }^{11}$.

Ainda que alterações bastante significativas sejam encontradas se comparadas a primeira e a mais recente versão dos aparelhos - como melhorias da qualidade das fotos, velocidade de processamento, entre outras - é plausível a constatação de uma certa neutralidade envolvendo a evolução de tais smartphones, de maneira que facilmente uma versão pode ser confundida com a anterior ou com sua sucessora. Ou seja, se hipoteticamente

\footnotetext{
${ }^{11}$ Cronologia obtida no site oficial da empresa: http://apple-history.com/iphone.
} 
possuímos um gadjet cuja versão corrente é a versão 6 , e o fabricante anuncia com exclusividade a versão $6 S$, de imediato infere-se que é uma versão melhorada e mais atual. Se poucos meses depois o mesmo fabricante anuncia a versão 6S2, novamente o consumidor é levado a crer que inovações não contidas na versão anterior estarão presentes, e assim sucessivamente, mesmo que este usuário não tenha consciência plena das inovações em si.

O fator que mais chama a atenção nesse fluxo do mercado (e nesse caso não só dos smartphones) é o de que uma grande parcela dos consumidores não busca o novo aparato em virtude de suas inovações, mas em busca de sentirem-se aptos a se apresentarem para a sociedade como seres atualizados, afinal ninguém quer ser visto como um indivíduo $1.0 \mathrm{em}$ uma sociedade repleta de indivíduos $5 S$. Em outras palavras, não seria surpreendente uma constatação empírica que apontasse a grande parcela de consumidores que adquirem a um alto custo financeiro um artefato recém-lançado sem que saibam apontar as reais melhorias entre o aparelho novo e o pré-existente. Talvez a minoria realize um upgrade devido a uma lacuna utilitária na versão anterior que foi preenchida na mais recente.

Essa realidade aponta para a inusitada impressão, senão fato consumado, de que os aparatos tecnológicos passaram de possuídos para possuidores, e de que houve uma inversão mercadológica, em que o usuário agora se tornou submisso ao bem, a ponto de substituir sua capacidade de reflexão acerca do bem desejado pelo impulso desordenado de obtê-lo sem mais detalhes e sem demora. Não é à toa que as grandes corporações líderes do mercado eletrônico, meses antes do lançamento de um produto, organizam um evento de ampla divulgação mundial somente para anunciar o artefato que em breve estampará as vitrines mundo afora. Dessa forma, quando o produto de fato chega às lojas, o consumidor já está quase irreversivelmente seduzido, a ponto de, como a esposa que aguarda por horas na estação a chegada do trem com seu amado, permanecer por horas, ou até dias ${ }^{12}$, em frente à loja para finalmente encontrar-se com seu "amado".

Aliás, essa necessidade de estar entre os primeiros usuários a colocarem as mãos no aparelho não deixa de ser um indicativo da escravidão mercadológica a qual tais consumidores se submeteram, bem como de uma possível carência de reflexão e autocontrole,

\footnotetext{
${ }^{12}$ Em matéria intitulada iPhone 5s: Line Stretches Around the Block at NYC Apple Store, a jornalista Angela Moscaritolo relata como foi a espera dos consumidores durante o lançamento do iPhone 5s em Nova York: " $A$ fila literalmente envolveu um quarteirão inteiro da cidade. [...] Os primeiros da fila aguardavam ali a mais de uma semana, enfrentando chuvas e quedas fortes de temperatura à noite, para estarem entre os primeiros do mundo a colocarem as mãos em um dos mais novos smartphones da Apple.” O primeiro da fila, um jovem de 19 anos, estava acampado juntamente com seu primo na frente da loja havia 15 dias, deixando o lugar "apenas para ir ao banheiro, comer, e tomar banho em uma academia de ginástica próxima. [...] Ele não foi para a casa em nenhum momento durante esses 15 dias." Disponível em: <http://www.pcmag.com/article2/0,2817,2424635,00.asp>.
} 
afinal, o mesmo produto continuará nas lojas pelos próximos meses, e parece muito mais coerente aguardar alguns dias para obtê-lo calmamente do que montar acampamento em frente à revenda por infindáveis horas para simplesmente estar entre os primeiros que adquirirão um artefato que dentro de alguns dias estará nas mãos de outros milhões de pessoas ao redor do planeta.

A estratégia da publicidade é justamente essa, e não seria justo nem apropriado culpala por todos os desequilíbrios e carências da sociedade. No entanto, parece fato inegável que existe uma "autonomia midiática" em nossa sociedade. Em outras palavras, os artefatos em demanda, bem como os que ainda virão, parecem possuir uma aura que os sacraliza, tornandoos autossuficientes simplesmente por existirem. Ao invés dos objetos só possuírem uma razão para existir a partir do momento em que são utilizados, o que temos testemunhado são os aparatos tecnológicos sobrevivendo por si só e se bastando, causando a impressão de que houve uma inversão, em que agora somos nós que precisamos deles para nos afirmar e justificar nossa identidade perante a sociedade.

Bauman acredita que “[...] um suprimento ininterrupto de ofertas sempre novas é imperativo para a crescente circulação de produtos, com um intervalo reduzido entre aquisição e alienação.” (2013: 20). Ou seja, o fluxo contínuo e ininterrupto do mercado não deixa sobrar tempo para o consumidor refletir acerca da real necessidade do produto, estimulando-o a adquirir o hábito da rotatividade de produtos, aproximando-o da alienação fruto da não-reflexão.

O autor ainda descreve com muita clareza essa estratégia do mercado e os riscos do impulso não-reflexivo dos consumidores:

Já que é impossível saber de antemão qual dos bens ou serviços oferecidos se revelará tentador o bastante para despertar o desejo dos consumidores, a única forma de separar realidade e pensamento positivo é multiplicar as tentativas e cometer equívocos caríssimos. [...] as ofertas são acompanhadas pela substituição por produtos 'novos e melhores'. Isso também é imperativo para evitar a situação em que outra decepção com produtos específicos se transforma em desapontamento geral em relação a um tecido existencial bordado com os fios do pico de consumo numa tela feita de redes comerciais. (2013: 20)

Em recente entrevista ${ }^{13}$, o professor e filósofo Clóvis de Barros Filho assim se referiu a essa relação do homem com a tecnologia no século XXI:

\footnotetext{
${ }^{13}$ Entrevista concedida no programa de televisão Mundo Melhor, exibido em canal aberto no dia 03 de maio de 2014. Disponível em: http://chalita.com.br/tvchalita/a-vida-que-vale-a-pena-ser-vivida-com-clovis-de-barrosfilho/.
} 
$\mathrm{O}$ mundo da técnica nos submerge em suas novidades que são apresentadas em uma velocidade espantosa. Então a cada dia nós temos artefatos novos para adquirir. Ao mesmo tempo, fomos perdendo a competência para discutir sobre a pertinência daquilo, o valor daquilo, a real serventia daquilo. Então de certa maneira passamos a consumir tecnologia de maneira completamente acrítica, de tal forma que basta que um produto seja apresentado no mercado para ele ser tomado como indispensável, fundamental, sem o qual a vida não pode ser boa. [...] Enquanto a técnica caminha em uma velocidade supersônica, a reflexão sobre o valor das coisas caminha em uma velocidade de tartaruga, de tal maneira que enquanto você está pensando: 'será que isso me convém?', já surgiram quatro gerações futuras daquele mesmo artefato. (BARROS FILHO, 2014).

Tal declaração toca também em um conceito amplamente utilizado no contexto publicitário, sendo em tal âmbito utilizado de maneira paralela ao seu real sentido etimológico, que é a palavra geração.

O termo geração fundamenta-se na ideia de raça, linhagem, reprodução. Refere-se à continuidade de algo. O termo em si não abarca a qualidade do ser/algo posterior, mas apenas indica sua origem. Entretanto, quando inserido no contexto publicitário, à palavra geração é adicionado um novo sentido: o de melhoria. Quando uma propaganda, independente de sua mídia de propagação, apresenta o termo geração, está implícita a ideia de avanço, aperfeiçoamento, evolução e progresso. Por isso é tão comum a utilização de chavões publicitários como “chegou a nova de geração de...", ou produtos que agregam este termo em seu nome, como ocorre na indústria automobilística ${ }^{14}$ e de eletrônicos ${ }^{15}$. Ao mencionar que "uma nova geração" de algum produto está a caminho, a mensagem ao consumidor é claramente a de que algo mais avançado está prestes a apagar seu antecessor, já iniciando o processo de sedução para com o consumidor do século XXI, deixando o usuário, a partir daquele anúncio, "pré-descontente" com seu aparelho presente. Todavia, a utilização do termo geração sob este molde da indústria do marketing parece desapropriado quando tratamos das mídias de gravação e reprodução sonora, e consequentemente de qualquer abordagem relacionada à escuta musical.

Ainda que de fato tenham ocorrido em tais mídias inúmeros progressos e melhorias em aspectos fundamentais - como a qualidade do material sonoro armazenado e a

\footnotetext{
${ }^{14}$ O exemplo mais popular é o do veículo Gol. No ano de 1994foi lançado o veículo Gol G2 (Gol Geração 2). Desde então a fabricante agrega a palavra geração a este veículo, sendo o lançamento mais recente o Gol G5 (2012 - 2014).

${ }^{15}$ Podemos mencionar como exemplo alguns modelos de computadores da Apple, como o PowerMac (19972005), que passou pelos modelos PowerMac G3/G4 e G5, e PowerBook (1997-2006), que teve duas gerações, o PowerBook G3 e G4. Outros aparelhos, como o iPod (2001-presente) seguem o mesmo princípio, tendo alguns de seus modelos, como o iPod Nano, atualmente na sexta geração.
} 
incorporação de tecnologias que possibilitaram a cópia e a reprodução do material sonoro isso não necessariamente torna uma mídia mais recente superior à anterior. Basta considerarmos que o rádio possui mais de cem anos de história e ainda é amplamente utilizado, inclusive sendo preferido acima de outras mídias mais recentes em determinadas circunstâncias.

Dessa forma, será falha qualquer tentativa de organização das sucessões de aparatos midiáticos de reprodução sonora ao longo da história em categorias fechadas e absolutas, partindo da premissa de que um smartphone é uma evolução, ou uma nova geração, do disco em vinil, por exemplo. Se em alguma instância é requerida a aplicação do termo geração no estudo das mídias (portáteis ou não), prefiro utilizá-lo referindo-me aos ouvintes, pois penso que as gerações de ouvintes e seus comportamentos diante das várias mídias concomitantes no mercado presente soam muito mais interessantes do que a pífia tentativa de rotular de maneira pejorativa determinadas mídias hoje já inexistentes ou não tão abundantes, mas que possuem peculiaridades tamanhas a ponto de "ressuscitar" com elegância em pleno século XXI, em meio a uma sociedade que aparentemente não precisaria resgatá-la, pois, seguindo o princípio publicitário, já estaríamos algumas gerações além, e nada traria de novo resgatar algo que por muito já foi ultrapassado. É o caso do vinil.

\section{O som do vinil}

Desde o final do século XIX, a tecnologia atrelada às mídias de gravação e reprodução sonora tem evoluído significativamente. Tomemos como marco inicial o fonógrafo, de Thomas Edison. Desenvolvido em 1877, utilizava-se de cilindros de cera para os processos de gravação elétrica e reprodução sonora. O fonógrafo ainda não era capaz de fazer cópias. No ano seguinte, em 1888, foi introduzido o gramofone por Emil Berliner, este sim com o avanço de possibilitar a reprodução e também a cópia, realizada através de discos feitos de gomalaca. Porém, ainda não se falava de fonografia, pois nenhum dos aparelhos tratava com relevância do consumo de música. Tal acontecimento viria à tona somente mais tarde com a instituição do formato da canção popular. Conforme os recursos de gravação elétrica foram se desenvolvendo, foi possível dar origem ao disco de 78rpm, suporte este que permitia a gravação de aproximadamente 4 minutos de música em cada um dos lados. Tal fato justificaria o estabelecimento de um padrão de duração das canções na cultura musical popular de massa até os dias presentes (TATIT, 2004). 
Na segunda metade da década de 1940 é então apresentada uma nova tecnologia em dois formatos: o disco em vinil, que seria apresentado pela empresa Columbia na versão Long-Play em 12 polegadas e 33 1/3rpm e uma versão da empresa RCA Victor, de 7 polegadas e que tocava em 45rpm. Mas somente a partir da década de 1950 é que este meio seria legitimado como o principal agente disseminador da cultura musical popular de massa.

Marcos históricos à parte, esta reflexão visa um aprofundamento maior no impacto cultural e comportamental do disco em vinil mais do que em sua origem por si só, pois muitos desses comportamentos continuam a ocorrer ainda na década de 2010, porém sob a influência de outra mídias. Mudam os protagonistas, permanecem as práticas.

O primeiro fator importante a ser considerado é a instituição do formato álbum. Apesar de nesse início de século XXI esse tipo de organização musical ter sido posto em xeque em virtude da liberdade de se criar playlists variadas, muito da cultura do vinil tem como base esse formato, pois

[...] ainda que o compacto representasse uma importante fatia do
consumo de música naqueles anos, é o formato álbum - entendido
como um produto fechado, com canções interligadas, com duração de
cerca de 40 minutos com lado A e lado B e acompanhado de capas,
encartes, textos apresentando o artista, ficha técnica, agradecimentos e
um título, lançados por um determinado grupo ou intérprete - que
garante ao disco a hegemonia dentro da cultura popular-massiva da
música. (SÁ, 2009: 59)

Em outras palavras, o disco feito de vinil era muito mais que um mero suporte de material sonoro. Aqui se percebe uma amplitude de significados, em que cada detalhe tinha seu valor no todo, desde a duração do disco até detalhes do encarte, ficha técnica etc. e isso seria refletido nos ouvintes, seja em seu estilo ou no estabelecimento de sua relação quase afetiva com a mídia.

Um fenômeno que esclarece esse vínculo entre o ouvinte e a mídia, nesse caso entre o ouvinte e o disco, é o conhecido como Sleeveface. Trata-se da utilização das capas dos discos de maneira que estas se apresentem como continuação, ou uma extensão da realidade. Seria o homem a continuação do disco ou o disco a continuação do homem? Conforme descreve a pesquisadora Simone de Sá, esse fenômeno seria “a humanização desse artefato técnico em contato com o corpo e a objetificação do consumidor a partir da identificação com o disco destacada em seu aspecto estético (a capa) a ponto de mimetiza-la.” (SÁ, 2009: 67).

Essa prática é relativamente nova, tendo sido disseminada na internet mundialmente entre os anos de 2006 e 2007, sendo inclusive destaque de capa da revista O Globo, com 
matéria intitulada A Turma do Vinil ${ }^{16}$. É possível, no entanto, achar registros mais antigos do Sleeveface, feitos talvez sem tanta pretensão de se estabelecer uma nova moda, como na capa do disco Slug Line (1979), de John Hiatt (figura 1), ou na contracapa do álbum Picture This (1982), de Huey Lewis and The News.

O Sleeveface, todavia, tem sido empregado como uma ferramenta de marketing informal da crescente campanha "o retorno do vinil", explicitada um pouco adiante, ou seja: gerações que sequer conviveram com o disco em vinil estão aderindo a campanhas que clamam pela sua volta, e interagindo de maneira mútua com os discos.

É interessante observar as entrelinhas implícitas nessa prática até certo ponto descontraída. Enquanto em um primeiro momento podemos falar de apenas um modismo virtual, o fato de tornar o disco uma continuação de si mesmo pode significar algo mais, e exprimir em algum grau o desejo de atribuir-lhe vida, organicidade. A aparente brincadeira de sobreposição fotográfica na realidade pode estar sugerindo o desejo de uma experiência muito mais profunda entre o disco e o ouvinte. O homem se objetifica e ao mesmo tempo vivifica o que por si só não tem vida.

E se tentássemos transpor o Sleeveface para fora da associação com o retorno do disco em vinil, inserindo-o na realidade das mídias portáteis? Qual seria o resultado? Um sujeito com 80 capas de disco no rosto? Creio que não. Carregamos inúmeros álbuns conosco, mas dificilmente há uma interação tão destacada e especial com algum específico, a ponto de o colocarmos no lugar de nosso rosto. Por essa razão é que me parece que a aproximação mais apropriada para o Sleeveface das mídias portáteis seria não a capa de um álbum, mas a foto de um pen drive ou de um smartphone.

\section{O retorno do disco em vinil}

O mercado fonográfico ultimamente tem falado com ênfase sobre o "retorno do vinil" ${ }^{\prime 17}$. Aquela tecnologia, da geração passada, teoricamente já superada e de baixa definição frente às novas mídias, parece ter surpreendido e tem a cada dia se mostrado mais presente,

\footnotetext{
${ }^{16}$ Revista $O$ Globo, suplemento dominical do jornal $O$ Globo, ano 4, n. 192, 30 de março de 2008. Capa e p. 2227.

${ }^{17} \mathrm{O}$ artigo intitulado Admirável vinil novo: o retorno dos discos na era do mp3 aborda com precisão o fenômeno do aumento de vendas dos discos de vinil nos últimos anos, bem como a disseminação do mote "o retorno do vinil" pela mídia nacional. Disponível em: <http://www.epublicacoes.uerj.br/index.php/contemporanea/article/view/3176>. Ver também matéria online intitulada $A$ volta dos discos de vinil: lançamentos nacionais, reabertura da única fábrica no Brasil e lojas de raridades impulsionam o mercado de vinis. Disponível em: <http://vejasp.abril.com.br/materia/a-volta-do-discos-de-vinil〉. São apenas dois exemplos entre inúmeros que apontam para o retorno do vinil no século XXI.
} 
adaptada às necessidades do consumidor contemporâneo. No Brasil há inclusive um programa de televisão dedicado exclusivamente a ele ${ }^{18}$, e em horário nobre, mostrando que a volta do vinil não é apenas um desejo de alguns poucos, mas tem contado com o apoio da grande mídia. Isso revela que há um público interessado nesse fenômeno (suficiente para sustentar a audiência de tal programa há oito anos), que pode ser composto tanto pelos aficionados da década de 1960 e 1970 quanto pelos mais jovens, engajados nessa tendência.

Na matéria intitulada $O$ retorno do vinil em plena era digital ${ }^{19}$, o jornalista Sérgio Albuquerque relata o anúncio, feito pelo USA Today em 2011, do lançamento de todos os álbuns dos Beatles em vinil pela Apple (gravadora original) e EMI. Da mesma forma, a banda Black Sabbath anunciou uma tiragem de toda a discografia dos anos 1970 - 1978 em vinil. A matéria também afirma um aumento de 3,9 milhões na venda de exemplares de vinil durante o ano de 2011; ou seja, não somente o vinil não desapareceu como tem conquistado as novas e antigas gerações em plena década de 2010, ainda que por motivos diferentes. O Sleeveface é uma prova disso.

Por influência da cibercultura, essa prática tem se propagado de maneira intensa na rede, e quase sempre vem acompanhada de textos que exaltam de alguma forma o vinil e pregam seu retorno. O canal de notícias online The Register recentemente trouxe uma matéria intitulada Selfies are over: welcome to the age of 'Sleeveface,20, a qual explicita, segundo o autor, que o termo selfie ${ }^{21}$ no ano de 2014 perderá o trono para o termo sleeveface, pois este refletiria a intersecção perfeita entre o narcisismo do selfie e o revival do vinil. Vários outros sites de revistas, blogs de variedades ${ }^{22}$ e $\operatorname{livros}^{23}$ apresentam matérias similares. A Apple

\footnotetext{
${ }^{18}$ Programa $O$ Som do Vinil, apresentado pelo ex-integrante da banda Titãs Charles Gavin, no Canal Brasil. O programa tem seu enfoque em LPs marcantes da discografia brasileira, e conta com entrevistados que discutem a importância de tais obras e revelam os bastidores do disco em pauta. Os entrevistados vão desde os próprios compositores a familiares, produtores e amigos dos artistas. Disponível em: http://canalbrasil.globo.com/programas/o-som-do-vinil/index.html.

19 A matéria encontra-se disponível na íntegra no endereço eletrônico: $\langle$ http://www.observatoriodaimprensa.com.br/news/view/_ed722_o_retorno_do_vinil_em_plena_era_digital $>$.

${ }^{20} \mathrm{http}: / /$ www.theregister.co.uk/2014/03/31/sleeveface_the_new_selfies/

${ }^{21}$ Abreviatura de self portrait, corresponde à versão contemporânea da palavra autorretrato. Normalmente é feito através de câmeras acopladas aos smartphones e tablets, no qual a pessoa pode posar sozinha ou em turma. Em 2013 o termo selfie foi introduzido na versão eletrônica do dicionário Oxford, que o consagrou como Palavra do Ano, após ter sido detectado um aumento superior a $17.000 \%$ no uso dessa palavra entre os anos de 2012 e 2013, segundo o site http://exame.abril.com.br/tecnologia/noticias/palavra-do-ano-selfie-se-consolida-como-mania-nainternet.

${ }^{22}$ Ver www.sleeveface.com, http://thechive.com/2012/05/18/vinyl-records-are-making-a-comeback-throughsleeveface-art-40-photos/, http://www.blipfoto.com/blog/2014/05/13/sleeveface-bring-life-back-to-old-recordswith-a-fun-photo-project e http://www.fiamfaam.br/momento/?pg=leitura\&id=1613\&cat=1 .

${ }^{23} \mathrm{Em} 2008$ foi lançado o livro Sleeveface: be the vinyl, de Carl Morris - o criador do termo Sleeveface. Apesar de se tratar de um livro puramente ilustrado com diversas montagens do gênero, o próprio título sugere uma ligação mais profunda entre o ouvinte e o material ouvido, de maneira que, sob essa perspectiva, um passa a fazer parte do outro.
} 
inclusive disponibiliza para download o aplicativo sleevefacer, no qual o usuário acessa capas de disco em um acervo digital e compõe seu próprio sleeveface pelo iPhone, iPad ou iPod Touch. Trata-se da concomitância das mídias.

Inúmeras razões, porém, contribuem para o retorno triunfal da cultura do vinil. A seguir trataremos de forma sucinta algumas das principais.

\section{Aconchego, estética e modernidade}

Marshall McLuhan ([1964] 1974) trabalha sobre a ideia de tatilidade, do encontro dos sentidos, afirmando que é possível uma relação produtiva entre eles, transcendendo assim o pensamento que por muitos séculos perdurou - como ele mesmo diz - da experiência isolada e unificada dos sentidos. Assim observa:

Começa a ficar evidente que 'toque' e 'contato' não se referem apenas à pele, mas ao jogo recíproco dos sentidos: "manter contato" ou 'estabelecer contato' é algo que resulta do encontro frutífero dos sentidos - a visão traduzida em som e o som em movimento, paladar e olfato (1974: 80).

Ao som do vinil costumam ser associados adjetivos como caloroso, aconchegante, vivo e real. É claro que essas descrições fazem mais sentido para quem vivenciou a era dos discos do que para quem nasceu em meio à disseminação do CD ou do MP3. Para esses, tais adjetivos não passam de um marketing favorável a aquela mídia. Mas ainda assim colaboram para a propagação dessa mídia.

Um dos fatores que ajudou a disseminar e colaborou para a aceitação do vinil em meio às gerações mais novas foi a cultura da música eletrônica. Através da figura dos $D J S$ os tocadiscos foram popularizados como instrumentos musicais, e consequentemente os discos de vinil se tornaram objetos de desejo. Mesmo em meio à utilização das altas tecnologias disponíveis no ramo, o toca-discos ainda tem seu lugar de destaque, muitas vezes atribuindo prestígio a quem o domina com primazia, como no caso do Turntablism ${ }^{24}$.

\footnotetext{
${ }^{24}$ Termo empregado para designar a prática de se criar música através da manipulação direta de discos em vinil em toca-discos. No início, o disk jockey (DJ) era responsável basicamente pelo controle de fade entre uma música e outra que tocavam em sequência. O turntablism se caracteriza pelo movimento dos discos, em tempo real e a critério do DJ (turntablist), de maneira que tal manipulação resulte em uma composição original. Apesar de o termo ser recente, a prática de se manipular sons e utilizar o toca-discos como instrumento musical não é nova. A música concreta e outros compositores experimentais já o faziam desde a década de 1930. A obra Imaginary Landscape $n^{\circ} 1$ (1939), de John Cage, por exemplo, possui em, sua instrumentação, dois toca-discos com velocidades de rotação variadas.
} 
Entre os argumentos dos defensores do vinil, como os DJs, frente às novas tecnologias, como o CD, estão:

De forma geral, o vinil é descrito como mais "natural", "caloroso",
"bonito" e "adequado" à atividade do DJ por oferecer todo o espectro
de frequências desejado (especialmente as mais graves), lhe permitir
colocar em ação técnicas de manipulação da mídia que lhe são
específicas e possibilitar o desenvolvimento de "mercados
alternativos" e de uma 'cena underground' dedicada à experimentação
estética de qualidade. Por outro lado, o CD é descrito como mais
"artificial", frio, feio e inadequado por não reproduzir fielmente os
sons subgraves, transformar o DJ em um 'apertador de botões', e estar
excessivamente ligado tanto à cultura de massas e à música comercial
esteticamente pobre e de baixa qualidade quanto à falta de
investimento financeiro nos próprios produtores e artistas provocada
pela cópia de arquivos digitais. (FERREIRA 2004:6 apud
PERPETUO e SILVEIRA, 2009: 61).

Outro aspecto bastante valorizado pelos entusiastas de tal tecnologia é a estética. As capas, encartes e informações técnicas agregam um alto valor à obra, fator literalmente minimizado no CD, uma vez que os discos traziam capas maiores, destacando a arte em um grau superior ao do CD. Até mesmo a fragilidade do disco feito de vinil se reverteu a seu favor, pois o cuidado com que se havia de ter no manuseio era tido como um fator de intimidade que contribuía para o vínculo entre as partes a partir do aumento do envolvimento e cuidado na experiência do ouvir.

Também se celebra a época vivida. É inegável que no discurso dos amantes do disco em vinil não estejam presentes traços de suas vidas, momentos e lembranças pessoais vinculados àquela mídia. É compreensível certa aversão às novas tecnologias, visto que essas vieram com o intuito de substituí-lo - e no mundo tecnológico isso significa tornar obsoleto e colocar em desuso - algo tão marcante em suas vidas, exigindo uma renúncia e um desapego nem sempre fáceis de concretizar.

Tal sentimento segue uma lógica não muito complicada de ser compreendida. A geração posterior à dos discos possui o mesmo apego pelo $\mathrm{CD}$, e terá um discurso pronto e de certo modo saudosista com a mídia que foi marcante em suas vidas e hoje já pode ser considerada parcialmente ultrapassada. E o mesmo desconforto do amante do vinil em adentrar na loja para comprar um CD está também presente no amante do CD ao comprar um veículo que não mais apresenta esse suporte, mas apenas entradas para pen drives ou smartphones. E por incrível que pareça, os argumentos serão quase os mesmos, com exceção da qualidade da gravação (mais notável entre o disco em vinil e o CD do que entre o CD e o 
MP3). As questões estéticas e artísticas relacionadas às perdas ocasionadas pela substituição do formato continuam as mesmas.

\section{Da saudade às lojas}

Sim, o disco em vinil está de volta, se é que um dia se foi. Hoje se encontra novamente nas prateleiras das melhores lojas especializadas, livrarias e lojas de departamentos. Obviamente que com os discos voltaram também as estantes e o toca-discos. Tudo exatamente como era antes... ou quase.

O toca-discos, apesar de manter seus moldes e forma de funcionamento tal qual era há décadas, teve de ser reinventado, a fim de reconquistar seu espaço na sociedade do século XXI. Afinal, os defensores do vinil dificilmente sustentariam todo um novo mercado por si só, assim como as fabricantes provavelmente não se sustentariam com um público-alvo tão restrito. A quase totalidade dos consumidores dessa última década (incluindo muitos das gerações anteriores) aderiu às inovações tecnológicas. Mais que isso, o mundo "embarcou" na tecnologia. Cada vez mais os aparelhos trabalham sob o regime da sincronia, de forma que todas as informações e arquivos de mídia estejam interligados e, independentemente do aparelho e da localização geográfica do usuário, os aparelhos devem estar acessíveis de maneira prática e rápida. $\mathrm{O}$ computador do trabalho está sincronizado com o smartphone que, por sua vez, está sincronizado com o computador residencial. Desse modo cria-se uma teia de forma que se um dado é alterado em um desses locais, a sincronia acontece de imediato em todos os aparelhos interligados.

Essa nova versão tecnológica faz compreender porque não haveria espaço para existência do toca-discos na sua forma tradicional. A solução encontrada foi adaptá-lo à sociedade de consumo do século XXI: com um design mais arrojado e moderno, mais robusto, entradas USB, limpador automático, e todos os demais recursos que a tecnologia oferece, inclusive alguns aparentemente paradoxais, como uma gaveta acoplada para CDs, caso o usuário queira converter o conteúdo de seus discos analógicos para o sistema digital.

Aqui nota-se uma espécie de conflito de gerações - não somente midiático - mas no sentido literal do termo. A propaganda dos DJs e da música eletrônica, atrelada ao discurso dos amantes do vinil, somados à tendência do mercado de ressuscitar sucessos do passado para as novas gerações, o disco em vinil não só retornou, mas retornou como artigo de luxo. $\mathrm{O}$ preço dos LPs geralmente supera o de qualquer outra mídia, seja ela CD ou DVDs em Blu Ray. Os tais toca-discos high tech ultrapassam o valor de lançamento de muitos dos mais 
cobiçados gadjets supracitados. E um exemplar desses no canto da sala voltou a impressionar os convidados. Em outras palavras, a dupla toca-discos/vinil se tornou cool, sinônimo de um ouvinte distinto, que aposta em uma experiência diferenciada e não massiva de apreciação musical. O resultado é a mistura de experiências musicais entre gerações, de forma que "enquanto os pais aprendem a usar o iPod com os filhos, estes fuxicam os vinis abandonados dos mais velhos e têm como objeto de desejo um toca-discos, vistos como cool e hype." (SÁ, 2009: 51).

\section{Compact Disc (CD)}

A prática da escuta musical foi se modificando ao longo do século XX, de acordo com o progresso das tecnologias associadas aos aparelhos de reprodução sonora. Até a chegada da década de 1980 - com exceção do rádio a pilha, popularizado na década de 1950 - a escuta mediada tecnologicamente ainda era de caráter fixo, de maneira que o ouvinte tinha que se deslocar até o local do aparato emissor. Mesmo o toca-discos, com todas suas inovações, ainda era grande e pesado o suficiente a ponto de tornar extremamente laborioso o processo de deslocamento do aparelho, assim como o disco em vinil em si não era de todo cômodo de ser transportado, seja pelo tamanho ou pela fragilidade do material por sua natureza em si e fragilidade associada a agentes externos, como a exposição ao sol.

O ano de 1983 marca o surgimento de uma nova mídia, o compact disc. Popularmente conhecido como $\mathrm{CD}$, o compact disc apresentou importantes inovações, que afetam desde questões relacionadas à reprodução sonora até as práticas de escuta. Um dos grandes avanços do $\mathrm{CD}$, que viria a influenciar nos hábitos de escuta do final do século $\mathrm{XX}$ foi o aumento na qualidade e pureza do material sonoro, conforme explicita Harry Crowl, em seu artigo intitulado A criação musical erudita e a evolução das mídias: dos antigos 78rpms até a era Pós-CD:

Já em 1966, o sistema Dolby era inventado com o objetivo de reduzir o ruído nas gravações causado pelo atrito do cabeçote dos gravadores com as fitas magnéticas por meio da compressão durante a gravação e a expansão durante a reprodução. Já estava claro aí que, além dos graus de distorção, o ruído branco, vulgarmente conhecido por ‘chiado', presente nas gravações, tornara-se insuportável para profissionais e consumidores mais exigentes. (CROWL, 2009: 149)

Assim, vê-se que talvez o maior trunfo do $\mathrm{CD}$ foi a capacidade de oferecer uma qualidade sonora consideravelmente superior à das mídias anteriores. Curiosa também foi a 
associação estabelecida, no surgimento dessa mídia, entre alta-fidelidade e repertório correspondente: O CD inicialmente era destinado apenas aos ouvintes de música erudita, pela suposição de que esses naturalmente possuíam uma escuta mais atenta e minuciosa exigindo, por conseguinte, uma qualidade sonora mais apurada ${ }^{25}$. Informa o compositor Harry Crowl que o primeiro $\mathrm{CD}$ foi comercialmente lançado por Akio Morita, co-fundador da Sony Corporation, um declarado apaixonado pela $9^{\text {a }}$ Sinfonia de Beethoven, interpretada por Karajan e a Filarmônica de Berlim. A capacidade de armazenamento da mídia teria sido então fixada em 70 minutos, que era a duração dessa obra musical executada na versão sob a batuta do maestro austríaco. (CROWL, 2009).

Essa capacidade de armazenamento do CD também foi um atrativo, pois era superior à dos discos em vinil e, ainda que fosse inferior à da fita cassete de 90 minutos, apresentava uma qualidade sonora superior a ambas, com níveis de ruído e distorção absolutamente desconsideráveis, abrangendo uma gama de $90 \mathrm{~dB}$, o que significa desde um sussurro até uma banda de heavy metal. (idem).

\section{Ascensão e morte do CD}

Uma vez instituída a mais recente mídia dominante, o CD teve sua utilização expandida, abafando por um momento histórico qualquer rastro dos aparelhos anteriores. As empresas do mercado musical precisaram rapidamente se adequar a essa nova realidade, e assim o mercado do CD foi sendo ampliado. Em 1990, por exemplo, a Sony Music relançou em CD a obra completa de Igor Stravinsky - regida e executada ao piano pelo próprio compositor - gravada pela gravadora CBS, durante os anos 1960 -1969.

No entanto, havia um diferencial importante no compact disc: agora o ouvinte poderia carregar consigo essas gravações, assim como na fita cassete, porém em alta qualidade. Visivelmente um CD era muito mais prático de ser transportado do que um disco, além de mais seguro, por ser a mídia em si de maior resistência. A força do CD, porém, ainda iria aumentar com a chegada dos aparelhos toca-CDs compactos e dos famosos Discman.

Discman foi o nome dado ao primeiro tocador de CDs portátil, desenvolvido pela mais uma vez pioneira Sony e introduzido no mercado no ano de 1984 com o modelo D-5 / D-50. Essa inovação portátil já anunciava o futuro da escuta, ou seja, em movimento e com alta

\footnotetext{
${ }^{25}$ Características da escuta estrutural, segundo Adorno (2011).
} 
qualidade sonora. Enquanto o Walkman permitia a portabilidade, o Discman fazia o mesmo e em hifi.

Como todas as inovações tecnológicas, no início ele era um artigo de luxo, com alto valor no mercado. Apesar de os primeiros modelos terem sido alvo de críticas, devido ao alto consumo de pilhas e ao peso, o aparelho logo se popularizou, valorizando ainda mais o CD no mercado fonográfico. Como substituto do Walkman, o Discman cumpriu seu papel, ainda que o já famoso antecessor tenha levado alguns anos até sair definitivamente de fabricação. $\mathrm{O}$ ciclo então se fechava. O CD se tornou uma mídia de alta qualidade sonora, resistente, de grande capacidade de armazenamento e o melhor: portátil. Tal domínio teve seu impacto não somente no mercado fonográfico, mas também na escuta musical dos ouvintes.

Podemos afirmar, sem muito receio, que os ouvintes e consumidores de música do terceiro milênio estão habituados à alta resolução sonora, a escuta em $h i$ - fi. A tolerância com ruídos e distorções no som foi reduzida a níveis quase nulos, de maneira que alguns estilos musicais que exploram tais sonoridades se veem em um constante embate com uma considerável fatia dos ouvintes, que prontamente os rejeitam ou rotulam pejorativamente por apresentarem sons categorizados como desagradáveis - entenda-se "distorcidos" e "ruidosos". Tal é o caso da Noise Music ${ }^{26}$.

Quando proporcionada a escuta a ouvintes regulares de CDs ou MP3 que não estão familiarizados com essa estética musical (ouvintes vinculados exclusivamente à escuta comercial), esse gênero provavelmente causará algum estranhamento, pois trará à tona uma série de frequências e sonoridades que uma escuta condicionada à "pureza" escondeu de seus ouvidos. Da mesma forma, enquanto os ruídos de um disco em vinil fazem o "charme" de seu som, esses mesmos ruídos, se contidos em um CD, trabalhariam no sentido oposto, certamente incomodando o ouvinte da geração posterior, que cresceu habituado a uma escuta clean e pura. Tal característica, entretanto, também é um dos principais motivos de crítica pelos que advogam a favor do vinil. Para estes, o som do CD de tão limpo se torna frio e sem vida, artificial e distante da realidade.

Outra maneira que o CD encontrou para se popularizar foi através da comercialização dos popularmente chamados "CDs virgens", como outrora aconteceu com as fitas cassete. Mas o CD virgem apresentava ainda outra vantagem, que era a possibilidade de se gravar materiais não-musicais, ou seja, dados. Com isso não só ouvintes se utilizavam dessa mídia,

\footnotetext{
${ }^{26}$ Estilo musical caracterizado e baseado, entre outras coisas, na expressiva utilização de ruídos dentro do contexto musical. Tal estilo costuma ser polêmico, especialmente entre ouvintes leigos ou acostumados à música de massa, por questionar os limites entre sons musicais e não-musicais, ou em outras palavras, o que é ou não é música.
} 
mas praticamente todos que lidavam com informática, pois pela capacidade, durabilidade e praticidade diante dos antigos disquetes, o CD se tornou a mídia oficial dessa categoria.

A Era do CD parecia insuperável. Ano após ano se comemorava a conquista de uma mídia tão prática e moderna que tornou os velhos vinis e disquetes obsoletos. A ironia, no entanto, é que enquanto o CD achincalhava seus velhos "colegas de trabalho" outra mídia estava prestes a eclodir, tornando-o igualmente obsoleto, e colocando-o no "hall dos esquecidos", ou se preferir, na mais recente estante do "museu das mídias".

Era a nova tecnologia digital, que chegava com força total, mas dessa vez com um aliado de força descomunal, como nunca se havia visto antes na história das mídias: a internet. Em termos práticos, o substituto direto do CD foi o MP3. No entanto, deve-se questionar até que ponto o verdadeiro substituto do CD não tenha sido a internet. O MP3, apesar das vantagens que lhe são próprias, teve como campo de disseminação a internet. Teria o MP3 sido um substituto tão eficiente na ausência dessa rede global de comunicação? Teria o formato se sustentado sem os smartphones e laptops?

Trata-se aqui de um formato digital, e não mais de arquivos embutidos em uma mídia palpável que para serem executados necessitam ser inseridos dentro de outro aparato próprio para decodificá-los. Para se ouvir um CD, por exemplo, precisa-se primeiro de um compact disc contendo o material sonoro. Com o conteúdo em mãos, agora se pede um aparato que o toque, como o Discman. O mesmo com a fita cassete e o Walkman. O MP3, por sua vez, dispensa a primeira etapa. Agora o que será inserido no tocador não é um artefato concreto portando o conteúdo sonoro, mas diretamente o conteúdo, em forma de arquivos digitais. Em suma, não é mais obrigatório um suporte material que porte as músicas a serem escutadas. Necessita-se somente de uma mídia que os decodifique, sendo esta mesma, na maioria das vezes, a mesma mídia que os executa, como o caso dos MP3 players, smartphones e afins. $\mathrm{O}$ local em que o conteúdo sonoro a ser escutado se encontra não é mais "dentro" de um vinil, cassete ou CD, mas "dentro" da internet.

Assim,

[...] o nosso velho conhecido CD "físico", com caixinha, folheto, ficha técnica e capa está mesmo agonizando, com seus dias contados e, em muito pouco tempo, terá sua função de difusão da música como produto completamente substituída pela internet, iPods e todos os periféricos mundo afora, isto é: a mídia digital. (PINHEIRO, 2009: 194-195).

Passemos, então, a uma descrição dos sucessores do disco compacto, o efêmero CD. 


\section{MP3 (MPEG Audio Layer 3): O formato e suas transformações na escuta}

A década de 2010 adentrou possuindo como formato dominante do mercado o MP3 como se convencionou denominar o MPEG Audio Layer 3. Mesmo com as lojas exclusivas de CDs ainda em funcionamento, parece já ter ficado óbvio para o mercado quais os caminhos que a música do século XXI tende a percorrer. Não se pode afirmar seguramente o seu destino, mas ao menos a "estrada trilhada" já aponta para algumas rotas bastante evidentes.

Especulações à parte, dados empíricos têm apontado para o crescimento do consumo de música via internet e a consequente diminuição da venda de CDs. Já em meados de 2012 a venda digital superou a física em grandes metrópoles, como o Reino Unido ${ }^{27}$. Constata-se assim, que "a venda virtual de música (downloads legais), mesmo com toda a pirataria existente e a falta de controle, tem se mostrado mais lucrativa do que a venda 'física' dos CDs." (PINHEIRO, 2009: 197).

Observa-se, dessa forma, um fenômeno da diminuição dos lucros das gravadoras relacionado à vendagem de CDs e um aumento significativo dos lucros das companhias de telefones celulares, eletrônicos e computação, associados ao comércio do MP3. (MILLARD, 2005).

O MP3 se destaca por ter sido um dos primeiros tipos de compilação capazes de comprimir arquivos de áudio com eficiência reconhecida. A redução no tamanho do arquivo pode alcançar 90\%, mantendo uma qualidade próxima à de um CD. Além disso, possibilitam o streaming, ou seja, o arquivo pode ser decodificado à medida que o download é realizado, não sendo necessária a conclusão da transferência do arquivo para iniciar sua reprodução, afirma o pesquisador Giuliano Obici (2008).

Em uma sociedade que visa à praticidade e a rapidez, o MP3 parece ter servido como uma luva, provando que as mídias não necessariamente se superam, mas se modificam com o tempo. Sendo assim, o MP3 agregou a portabilidade do rádio à pilha, a possibilidade de escolha do próprio repertório fornecida pelo Walkman e a alta qualidade sonora do CD em um mesmo formato. Esses fatores, somados ao fato de serem arquivos de tamanho reduzido e à alta possibilidade de disseminação de tais arquivos viabilizada pela internet, coroaram esse formato como o dominante nesse início do século XXI.

\footnotetext{
${ }^{27}$ Uma matéria publicada no jornal O Estado de São Paulo no dia 01 de junho de 2012 mostra que as vendas digitais superaram, pela primeira vez na história, a venda física de CDs. Enquanto naquele ano a primeira cresceu 2,7\% a segunda diminuiu 15\%. Disponível em: http://www.estadao.com.br/noticias/impresso,mp3supera-o-cd-no-reino-unido, $880835,0 . \mathrm{htm}$
} 
A "era da portabilidade" do MP3 iniciou-se em 1998, com a chegada dos primeiros tocadores portáteis capazes de armazenar e tocar músicas comprimidas nesse formato. Agora era somente uma questão de tempo para os ouvintes perceberem que havia algo muito mais conveniente que o $\mathrm{CD}$ ao alcance.

Em virtude da alta taxa de compressão que gerava arquivos reduzidos, os tocadores portáteis eram capazes não só de armazenar milhares de músicas, mas também de categorizálas em gênero, artista, álbum, título ou listas automáticas. Isso possibilitou o desenvolvimento de uma nova e inédita forma de se escutar, pois o ouvinte agora carregava no bolso não mais uma fatia de seu repertório em fitas e CDs, mas sua discoteca inteira.

Para termos uma noção mais específica das transformações associadas às práticas da escuta musical ao longo dos anos, relembremos e comparemos os dois extremos: Anteriormente ao advento das mídias, a escuta necessitava da presença física do intérprete, sem o qual não se ouvia música. No início do século XX, a escuta musical mediada pelo fonógrafo já permitia se escutar na ausência do músico, porém era uma escuta limitada a alguns poucos minutos de gravação e ao ambiente no qual se encontrava o aparelho. Após aproximadamente um século, os ouvintes carregam consigo milhares de músicas em um mesmo aparelho portátil e trocam de gênero tão rapidamente quanto se muda o canal da televisão. A música, antes fixa, agora se tornou companheira inseparável, e diria insubstituível, do ouvinte. A música não é mais esporádica, mas constante nos ouvidos dos transeuntes das grandes cidades. Os estímulos sonoros atentam sem cessar contra os ouvidos, principalmente quando se luta contra a paisagem sonora externa do ambiente, e a música passa a ter um papel de agente psicológico efetivo, que se transmuda de acordo com as variações do estado de espírito do ouvinte ao longo do dia. Como certas práticas da música oriental, em que se tem uma melodia para cada estação do ano ou mudanças climáticas, a escuta nômade fornece um repertório adequado a cada ambiente ou estado de espírito.

Ressalta-se que a portabilidade não teria sido possível sem a emergência da internet, principal meio de disseminação e compartilhamento do MP3. Além da possibilidade de se transferir arquivos (legal ou ilegalmente) pela rede, a consolidação do formato se deu com a chegada dos tocadores portáteis. Em 2001 a Apple lançou seu primeiro iPod, branco e bastante conciso no tamanho. Não era em absoluto o primeiro tocador do mercado, porém possuía características bastante sedutoras:

[...] devido a sua simplicidade, design arrojado e à alta efetividade publicitária da Apple, o iPod se tornou o primeiro aparelho digital portátil de música do mercado a ser tido como objeto de desejo. Rapidamente, conforme as pessoas se desfaziam de seus Walkmans e 
Discmans, o iPod com seus earbuds ${ }^{28}$ se tornariam ubíquos e icônicos. (ANDERSON, 2008: 34)

Acerca das capacidades da mídia, o autor acrescenta:

O que realmente era chamativo no iPod era sua capacidade de armazenagem, que podia alcançar sessenta gigabytes. Isso permitia que os usuários carregassem suas bibliotecas de som inteiras, chegando a dez mil músicas, o que equivale ao conteúdo de uma pequena loja de discos. (2008: 34)

Ainda discorrendo sobre o novo público-alvo das mídias portáteis, que constituem uma grande parcela dos ouvintes desse suporte, os autores Alice de Carvalho e Riverson Rios afirmam:

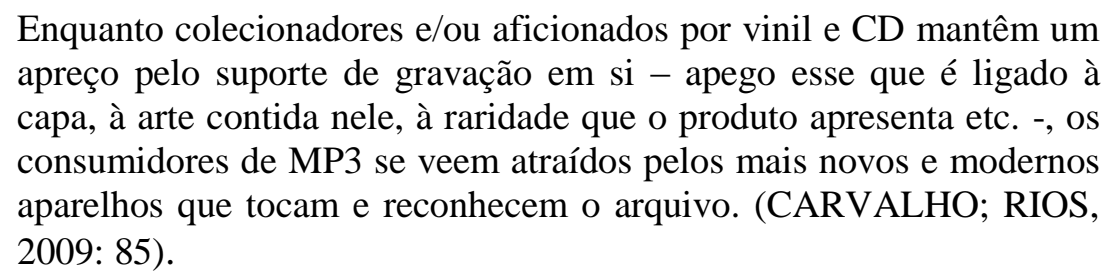

Com o auxílio das emergentes redes sociais, especialmente aquelas direcionadas para o compartilhamento e divulgação de músicas (como o Myspace e o SoundCloud), o formato MP3 se consolidou de maneira indiscutível, mas não somente como formato em si. A escuta musical foi impactada profundamente, a ponto de podermos afirmar que tão radical quanto foi a mudança do fonógrafo para o toca-discos analógico, foi a do CD digital para o MP3.

No entanto, a história já provou que não se deve apegar-se ao que é transitório, e todas as mídias são em alguma instância transitórias. É fato que o MP3 um dia será substituído por outro formato, pois o ciberespaço é regido pela lei da conveniência e praticidade, e em hipótese alguma se deixará ser ancorado. Está só aguardando alguma inovação mais apropriada para mover o então soberano MP3 para a estante do "museu das mídias" logo ao lado do CD.

\footnotetext{
${ }^{28}$ Nome dado pela empresa aos fones de ouvido que acompanham alguns de seus gadjets.
} 


\section{CAPÍTULO 3}

\section{O WALKMAN}

\section{O Walkman}

O século XX pode ser considerado um período em que grandes mudanças no campo tecnológico aconteceram em um curto período histórico. Basta compararmos a distância de formatos entre o fonógrafo e o MP3, e as transformações ocasionadas por elas na escuta musical no decorrer desse período.

Introduzido no mercado no ano de 1979 pela Sony ${ }^{29}$, o Walkman se situa quase no topo dessa pirâmide midiática, já muito mais próximo do MP3 do que do fonógrafo. E traz consigo muitas similaridades com as mídias portáteis do final do século XX.

Assim como a geração do século XXI tem nos smartphones e iPods mais que aparelhos, mas uma cultura e um estilo de vida, esse mesmo efeito foi observado no Walkman durante as décadas de 1980 e 1990. Tamanha era sua popularidade que nos anos de 1989-90, dez anos após seu lançamento, a Sony ainda controlava aproximadamente $45-50 \%$ do mercado nos Estados Unidos, e 46\% no Japão (SANDERSON; UZUMERI, 1997: 102).

\section{A cultura da mobilidade}

Seu lançamento foi em julho de 1979 no Japão. Durante o primeiro mês as vendas em nada impressionaram, fazendo os funcionários da Sony se questionarem a respeito do investimento. Entretanto, a partir do mês seguinte as vendas aumentaram significativamente, sendo que “[...] as primeiras trinta mil unidades foram vendidas até a metade de setembro, e para o resto do ano a produção teve que ser dobrada ou triplicada a cada mês" (NATHAN, 1999: 154). Com esse fluxo, apenas no primeiro ano de vendas no Japão, a Sony vendeu quase 500 mil aparelhos.

\footnotetext{
${ }^{29}$ Apesar de reconhecida mundialmente como a empresa criadora do Walkman, a Sony enfrentou uma dura batalha judicial com o inventor teuto-brasileiro Andreas Pavel. Pavel alega que já em 1972 criou o chamado Stereobelt, um aparelho portátil baseado no mesmo princípio e com a mesma finalidade do Walkman. Pavel patenteou a invenção em 1977 e tentou vende-las às grandes companhias, sem sucesso. Alguns anos após sua invenção a Sony introduziu no mercado o Walkman, iniciando um longo ciclo de batalhas judicias com Pavel, vencidas pelo brasileiro em 2004, polemizando o fato de que o Walkman pode ter sido, no final das contas, inventado no Brasil. Disponível em: http://info.abril.com.br/aberto/infonews/062004/07062004-1.shl. Consulta em 12 jun. 2014.
} 
Assim como se vê como os novos gadjets, uma minuciosa estratégia de marketing foi realizada pela fabricante. Antes mesmo do lançamento oficial, aproximadamente uma centena de aparelhos foram distribuídos para pessoas consideradas influentes, incluindo editores de revistas e músicos, como os da Orquestra Filarmônica de Berlim e Nova York. A expectativa era a de que tais orquestras ajudassem a divulgar o aparelho em seus territórios.

Akio Morita, co-fundador da Sony, tinha plena consciência que o ponto forte de seu aparelho estava associado à mobilidade. Se alguém necessitasse chegar a algum lugar depressa, o Walkman o acompanharia no mesmo passo.

Morita reconhece que seu parceiro, Masaru Ibuka, foi peça fundamental na elaboração do Walkman. Ele conta: A ideia veio à tona quando Ibuka um dia entrou em meu escritório
com um de nossos toca-fitas à pilha na mão e um par de fones de
ouvido convencionais. Ele parecia descontente, e reclamou sobre o
peso do aparelho. Eu perguntei o que se passava pela sua cabeça, e ele
explicou: 'Eu gosto de ouvir música, mas não gosto de atrapalhar os
outros. Eu não posso ficar sentado ao lado de meu toca-fitas o dia
todo. Essa é minha solução - eu carrego o aparelho comigo. Mas é
muito pesado.'Eu fiquei pensativo com aquela ideia na cabeça por
algum tempo, e aos poucos a ideia começou a se formar enquanto
Ibuka falava. Eu sabia, a partir de minha própria experiência em casa,
que os jovens parecem não conseguir viver sem música. Quase todos
possuem um rádio em casa ou no carro. Em Nova York, ou mesmo em
Tokyo, tenho visto pessoas carregando imensos toca-fitas nos ombros
escutando música. Lembrei-me de um dia em que minha filha, Naoko,
voltando de uma viagem, correu para seu quarto, antes mesmo de
cumprimentar sua mãe, para primeiro colocar uma fita para tocar em
seu aparelho. A reclamação de Ibuka me gerou essa iniciativa.
(MORITA,1986: 79)

O Walkman veio como uma resposta à reclamação de Ibuka, ao mesmo tempo em que Morita percebeu uma constante procura dos jovens pela música, o que incluía sua própria filha.

A origem do Walkman, no entanto, tem suas controvérsias. Autores como o musicólogo Shuhei Hosokawa (1984) e o antropólogo e sociólogo Iain Chambers (1994) sugerem que a ideia veio primeiramente do próprio Morita, e não de seu sócio. Até mesmo versões bem-humoradas e de tom satírico foram disseminadas, como a do jornalista Brian Thomas que, ao escrever sobre os vinte anos do Walkman, descreveu sua própria versão a respeito da origem do aparelho:

No final da década de 1970, o co-fundador da Sony, Akio Morita (sem nenhuma ligação com Pat) estava em mais um momento longo no banheiro sem nada para ler. O Walkman então nasceu. 'Eu gostaria de ouvir Toshinko Kundabi (o famoso grupo do estilo disco Japonês) e 
não conseguia me levantar do assento para ir ao quarto vizinho ligar o som.', disse Morita. 'Essa foi a primeira vez que desejei um tocador portátil.' (THOMAS, 1999).

Mesmo se tratando de uma sátira, tal registro serve para ilustrar a popularidade do aparelho e a influência que exercia na cultura como um todo. Outro aspecto que favoreceu a disseminação da cultura do Walkman foi a estratégia publicitária empregada pela Sony. Desde o princípio a companhia debruçou-se sobre o fator mobilidade:

\begin{abstract}
Morita ajudou a elaborar os primeiros anúncios impressos, que tinham como público-alvo os jovens e ativos, enfatizando sempre a velocidade e mobilidade: uma garota de cabelos longos ao vento correndo em sua bicicleta ${ }^{30}$, outras jovens em seus patins com shorts de verão ${ }^{31}$... um pôster mostrava um Walkman ao lado de três pares de tênis. (NATHAN, 1999: 153)
\end{abstract}

O sentimento de que o Walkman poderia acompanhar o ouvinte aonde quer que este se encontrasse era visto como um fator de comodidade para os usuários.

O lançamento do Walkman II em 1981 consolidou o aparelho como um símbolo de estilo de vida e instituiu o início de uma cultura, no âmbito social e musical - do ouvir.

Entre 1979 e 1990 a Sony lançou oitenta modelos diferentes de seu tocador portátil. Ao longo desse período o Walkman se tornava cada vez mais uma palavra falada ao redor do mundo e, como Morita tinha predito, o tocador portátil, juntamente com seus fones de ouvido, consolidou um novo modo de ser, tornando-se o símbolo da juventude (NATHAN, 1999).

Com essa estratégia de sucesso, Morita conseguiu estabelecer a cultura de que sair de casa portando aquele aparelho na mão e outro aparato na cabeça - os fones de ouvido significava estar na moda, ser moderno e cool. Exatamente como ocorre com as mídias portáteis desse início de século XXI. Portar um Walkman era sinal de status nos anos 1990, assim como colar no automóvel o adesivo de uma maçã $\tilde{a}^{32}$ em 2014 também o é.

O professor e sociólogo Paul du Gay, em sua obra Doing Cultural Studies, mostra como o Walkman era apresentado como uma moda, como algo que era moldado de acordo com o corpo humano, feito para se usar, parte da autoimagem e do estilo de se viver. Assim como a lycra para um ciclista, o Walkman seria a extensão da pele do ouvinte, tendo até mesmo os fones de ouvido sido desenvolvidos no formato perfeito do ouvido humano (du GAY, 1997). Essas ideias tangem também as reflexões de Marshall McLuhan ([1964] 1974),

\footnotetext{
${ }^{30}$ Cf. Figura 3

${ }^{31} \mathrm{Cf}$. Figura 4

${ }^{32}$ Referência à marca Apple.
} 
quando este reflete sobre a maneira com que os meios de comunicação passaram a integrar nosso cotidiano, tornando-se como partes de nosso corpo.

Enquanto isso, a estratégia de popularização aumentava, ao passo que as celebridades eram fotografadas usando Walkman. O jornalista Tom Zito, então do Washington Post, relata as estrelas do tênis Vitas Gerulitas e Bjorn Borg "vestindo"33 seus Walkman. Ídolos pop como Britt Ekland, Suzanne Somers e Paul Simon também teriam sido vistos portando seu aparelho. E finalmente, Diana Summer teria dado Walkmans às dúzias a seus amigos, como presente de Natal. Até o consagrado Andy Warhol chegou a afirmar: "Eu uso o meu (Walkman) a todo instante para ouvir ópera. É bom ouvir Pavarotti ao invés de buzinas de carros.” (ZITO 1981, apud DOWNEY, s/d: 9).

No dia 07 de dezembro de 2006, na New York Magazine, Nancy Mckeon e Corcky Pollan republicaram uma antiga matéria, datada de 1981, intitulada "Great gifts - 107 ideas for the wardrobe, the table, the kids, the home, the body, the mind, and just for the hell of it", a qual trazia o seguinte anúncio de uma loja de calçados da Madison Square, em Nova York: "É óbvio que você pode ouvir seu Walkman Sony sem essa capa opaca de couro de jacaré de \$600. Mas você quer? Na Vittorio Ricci.” (MCKEON; POLLAN apud DOWNEY s/d: 10).

Dessa forma o Walkman se consolidava como um artigo essencial, uma espécie de must-have que simbolizava uma nova geração, instituindo uma forma de se viver, vestir e ser, sendo "[...] simultaneamente um instrumento técnico e uma atividade cultural, [...] uma realidade imediata histórica" (CHAMBERS 1994: 51), exatamente como os recentes smartphones, tablets e iPods fazem na década de 2010.

Apesar de ter sua produção descontinuada apenas no ano de 2010 - o que representa uma vitória frente às mídias concorrentes mais recentes, e após aproximadamente 200 milhões de exemplares vendidos, não foi descontinuada, nem nunca será, a importância do Walkman no cenário da escuta musical. Por este motivo este trabalho dedicará mais espaço para a discussão do Walkman, mas não do aparato em si ou sua trajetória histórica, mas nas modificações proporcionadas por ele na escuta musical, hábitos até hoje presentes nas mídias portáteis, razão principal para que o recorte histórico dessa pesquisa inicie no Walkman. Assim, toda a discussão aqui proposta não deve ser tida como uma simples recapitulação histórica do aparelho, mas deve ser trazida para o momento presente, visto que todos os aspectos da escuta musical abordados nesse capítulo - a partir do Walkman - representam

\footnotetext{
${ }^{33}$ No original o autor emprega o termo wearing, derivado do verbo to wear, utilizado para se designar as roupas que veste.
} 
práticas ainda presentes nas mídias portáteis do início do século XXI, estabelecendo assim uma conexão direta entre essas mídias.

\section{A inédita escuta personalizada e portátil}

De alguma forma podemos ter o Walkman como um predecessor dos smartphones e iPods. Dentre as várias inovações do aparelho, como o peso leve, a praticidade e o fato de possuir energia de funcionamento própria, duas se destacam: a portabilidade e a confecção de playlists pelo próprio usuário.

A portabilidade em si não foi uma criação inédita do Walkman, pois décadas antes o rádio à pilha já o fazia. A novidade trazida por ele vem atrelada à capacidade do usuário criar sua própria sequência musical. Com o rádio à pilha era possível carregar a música consigo, no entanto era impossível para o ouvinte escolher o que escutar. O Walkman foi a primeira mídia que possibilitou ao ouvinte escolher ele mesmo as músicas que o acompanhariam, e editá-las como desejasse, na sequência que ele desejasse. Essa portabilidade sim foi inédita, a de montar e carregar a própria playlist. E essa inovação não causou impacto somente no âmbito tecnológico, mas modificou também a maneira de se ouvir. Nunca antes na história da escuta o ouvinte foi capaz de compilar suas músicas prediletas, independentemente do álbum em que se encontravam, e concentrá-las em um mesmo aparelho, nesse caso, em uma mesma fita cassete, e posteriormente carregá-las a tiracolo em uma mídia portátil. De acordo com o sociólogo e musicólogo Simon Frith,

[...] o fonógrafo veio a significar que as atuações musicais públicas podiam agora ser escutadas no âmbito doméstico. O gramofone portátil e o transistor de rádio deslocaram a experiência musical até o dormitório. O Walkman da Sony possibilitou que cada indivíduo confeccionasse seleções musicais para a sua audição pessoal, inclusive em espaços públicos (apud HERSHMANN, 2007:74).

Daniel Barbiero também considera essa nova prática de escuta, e suas consequências:

A maioria das músicas se tornou uma música que acompanha nossas ações, não importa o gênero ou o que se faz enquanto é ouvida. O profissional com seu Walkman, lendo o Wall Street Journal ou o Foreign Affairs no ônibus de manhã, pode estar facilmente ouvindo tanto a um quarteto de Schoenberg quanto aos últimos lançamentos de Crosby, Stills, Nash e Young. A música se tornou uma textura de background para a vida cotidiana. (1989: 147)

A possibilidade de se trabalhar e interferir no conteúdo musical a ser posteriormente escutado, além de implicações no processo de escuta musical, também reverberou na relação 
compositor-ouvinte. Ao passo que os ouvintes agora editavam sua própria seleção musical, passaram a interferir de maneira mais direta no material sonoro, colaborando para a criação de um material inédito e personalizado. Então coletâneas nunca antes ouvidas passaram a ser elaboradas, e ainda hoje podem habitar cantos de estantes ou fundos de gavetas de inúmeros ouvintes da geração Walkman. Agora o ouvinte não era mais passivo, mas agente transformador e criador, atitude que lhe atribuía certa autonomia e independência frente a seu objeto de escuta. Pouca expertise é requerida nessa prática. Quase nenhuma se comparada à requerida para se compor e gravar uma canção, como exige o ofício da figura tradicional do compositor. Podemos nos referir a tais ouvintes como ouvintes-compositores.

\section{A música caminhante}

O Walkman inaugurou uma prática de escuta em que o ouvinte escolhia seu próprio repertório e o levava consigo por onde fosse, portando apenas seus fones de ouvido. Essa prática, de "escuta solitária", pode ocorrer em diversas situações e sob diferentes perspectivas e intenções, de acordo com o interesse de cada ouvinte. Sob a importância de estudos dessa prática, Tia DeNora explicita que “[...] o foco na prática musical íntima, privada, ou na interação homem-música $u m-a-u m$, oferece uma vantagem ideal no estudo da música 'em ação"” (2000: 46). Ou seja, além da ubiquidade existiriam outros fatores significativos de serem aprofundados nessa escuta solitária.

Chambers (1994) examina um exemplo de interação ligado à escuta solitária; nesse caso na relação entre o ouvinte e os demais transeuntes a seu redor, destacando o processo de transferência da escuta coletiva para a privada:

O Walkman tem oferecido acesso a uma trilha sonora portátil que, ao contrário do rádio transistor, toca-fitas de carros e à explicitamente contrária intenção do 'ghetto-blaster' ou 'boogie box' - exagerados de graves, é, acima de tudo, uma experiência privada intensa. (1994: 49)

A expressão "escuta solitária" refere-se ao fato do Walkman ser direcionado a uma escuta individual, através dos fones de ouvido. Tal expressão não significa que não exista interação alguma com as pessoas ao redor, ou com a paisagem sonora do ambiente externo. Aliás, ao contrário do que a primeira aparência do Walkman sugere, grande parcela das práticas de escuta (a serem minuciosamente discutidas adiante) vinculadas à presença de fones de ouvido, está ancorada diretamente na relação com o ambiente externo. 
A socióloga Jody Berland (1998) afirma que os hábitos de escuta foram alterados com a portabilidade, mas também estão atrelados à sucessão das mídias:

As práticas de escuta são continuamente transformadas pelas inovações técnicas de reprodução sonora: os álbuns em long-play, o rádio transistor, e o Walkman tiveram cada um sucessivamente moldado e mobilizado nossas práticas de escuta, nos possibilitandonos carregar a música 'pertencente' a um lugar ou escala espacial para outros lugares. (1998: 133).

A portabilidade do Walkman é, em muitas situações, um exemplo de escuta distraída. Mesmo com os mediadores ditos "fixos", como o fonógrafo e o toca-discos, essa forma de escuta era presente, uma vez que não é limitada pelo fator movimento ou locomoção. No entanto, a partir do momento que a escuta é transportada a outros ambientes, posta muitas vezes em caráter secundário, o ouvinte poderia então experienciar essa forma de apreciação musical, defendida por Szendy (2008) e Truax (2001).

A relação gerada entre a escuta passeante e o ouvinte-compositor fundamenta-se em um ouvinte ativo, que possui controle e intenções sobre o que será ouvido. É uma escuta direcionada, quase sempre envolta por um desejo e um objetivo, seja ele a distração ou a tentativa de anulação do ruído externo. John Sloboda, autor de trabalhos sobre a chamada psicologia musical, enfatiza a figura desse ouvinte contemporâneo, apresentando-o como “[...] um agente ativo, que toma decisões sobre qual música ouvir, onde e quando ouvir, e qual o motivo de se ouvir, de acordo com suas necessidades, objetivos e propósitos" (1999: 355).

Tal perspectiva permite-nos inferir que a música, quando escutada em movimento, possui uma finalidade, a ser definida pelo ouvinte no momento da escuta.

\subsection{As funcionalidades da escuta em trânsito}

Michael Bull, professor no Departamento de Mídia e Filme da Universidade de Sussex, na Inglaterra, é respeitado como uma das maiores autoridades no estudo do impacto social das mídias portáteis, ou personal stereos. Com vasta obra publicada acerca do Walkman, Bull (ou Professor iPod, como ficou popularizado pela mídia), contribuiu para uma melhor compreensão das funções exercidas através da escuta móvel, e consequentemente alguns de seus efeitos no convívio social dos ouvintes.

Bull (2000) propõe dez estratégias de utilização do Walkman, sendo que tal análise se limita às formas de utilização do aparelho que envolvam modificações de interação entre o 
ouvinte e o ambiente ao seu redor. Como resultado, tem-se uma lista de dez exemplos de utilização típica do Walkman, as situações em que tipicamente ele é empregado e as motivações do ouvinte em usá-lo.

Bull (1999: 2000: 2001: 2002), assim como Shing-Ling Sarina Chen ${ }^{34}$ (1993), discutem o Walkman a partir das funções que essa mídia oferece para os ouvintes, e os motivos pelos quais esses são atraídos pelo aparelho. Chen afirma que "[...] os indivíduos manipulam o Walkman à luz das situações nas quais ele é usado, e se utilizam do Walkman para atingir objetivos específicos." (1993: 89), e prossegue sugerindo que “[...] a mobilidade do Walkman permite aos ouvintes mesclar seu uso em meio a outras atividades simultâneas". (1993: 92). Assim, a escuta móvel se apresenta como uma experiência multissensorial, resultante da combinação de estímulos externos e o ambiente interno do ouvinte, ou seja, o dos fones de ouvido.

Todavia, a análise de tais autores tende a se limitar no aparato em si, não centralizando a discussão na música transmitida por ele. Ou seja, a portabilidade do Walkman, e não necessariamente a música veiculada por ele, é que fundamenta a compreensão da funcionalidade do aparelho.

Por essa razão, esse trabalho prosseguirá sobre uma reflexão sobre tais discussões, tentando propor uma abordagem ao tema com foco na escuta musical proporcionada pelo Walkman, o material sonoro transmitido por ele, e não no aparato por si só, ressaltando que a resultante dessa análise será posteriormente válida e de completa aplicação às mídias portáteis do século XXI.

As dez funcionalidades da música portátil serão divididas em três grandes grupos, cada um com suas respectivas subdivisões:

\section{Funcões da música portátil (segundo Bull)}

I. Usos em que a música escutada é o centro da atenção

1. Escolha do material sonoro

II. Usos centrados na relação entre o ouvinte e o ambiente

2. Estetização

3. Controle do ambiente

4. Demarcação de território

5. Mediação interpessoal

III. Usos em que o ouvinte centra a atenção em si próprio

\footnotetext{
${ }^{34}$ Professora do Departamento de Estudos em Comunicação da University of Iowa, Chen foca seus estudos nas tecnologias de informação, o indivíduo e a comunidade. Seus estudos incluem a construção de um "eu" narcisista a partir do Walkman, bem como a apresentação do "eu" no ciberespaço. Disponível em: <http://www.ir.uni.edu/OSP/browsescreen2.cfm?dept=Communication\%20Studies\&idNo=256>
} 

6. Companhia
7. Memória auditiva
8. Controle do estado de espírito
9. Controle de tempo
10. Estímulo

\section{Usos em que a música escutada é o centro da atenção:}

\section{Função $\mathrm{n}^{\mathrm{o}}$ 1: Escolha do material sonoro}

Uma das maiores inovações do Walkman foi proporcionar aos ouvintes a possibilidade de escolha do repertório a ser escutado, e visto que cada ouvinte tem seus próprios desejos por um repertório particular, essa inovação pode ser considerada bastante significativa. Essa primeira função se caracteriza pelo preenchimento do desejo do usuário de usufruir dessa liberdade de escolha, acompanhado do desejo de preenchimento de uma satisfação futura em escutar o material selecionado. O ouvinte apreciaria o fato de experienciar uma escuta na qual ele já sabe exatamente o que será ouvido, e na qual não existiria margem para uma música que o desagrade subitamente saltar-lhe nos fones de ouvido, como ocorre quando se escuta rádio, por exemplo. Em outras palavras, seria o prazer do ouvinte de escutar ininterruptamente sua própria seleção, satisfeito pela possibilidade de carregá-la por onde for. (BULL 2000: 187).

A percepção da música como fonte de satisfação não é datada do século XXI, mas há séculos acompanhou os ouvintes, mesmo muito antes do desenvolvimento das tecnologias de reprodução sonora. Por volta de 330 a.c Aristóteles já observava que muitos homens se aproximavam da música com impulsos relacionados ao prazer que ela proporcionava, elevando-a como "[...] o princípio de todos os encantos da vida." (ARISTÓTELES, ([330ac] 2005: 39). Ele não a coloca como elemento fundamental para a vida, como seria a escrita usada para o comércio, ciências ou administração doméstica - mas reconhece sua utilidade para se "passar agradavelmente o lazer" (2005: 40). Observa o filósofo:

[...] Há na música um prazer que toca à mesma natureza, que encanta todas as idades, todos os caracteres, e que faz agradável o seu culto. [...] Não se deve julgar a influência que ela pode desempenhar no coração e na alma. [...] Ora, que realize ela esse efeito é evidentemente comprovado pelas árias melodiosas de muitos músicos, sobretudo do Olimpo. Tais árias, que todos aceitam, despertam o entusiasmo na alma. (ARISTÓTELES [330ac] 2005: 165) 
Stephen Davies (2001), na obra The New Grove Dictionary of Music and Musicians afirma que "[...] as obras musicais são valorizadas pelo prazer que proporcionam em sua apreciação.” (2001: 623). Mesmo tratando do processo de recepção musical, e não propriamente da música em si, Davies reconhece a capacidade que a música traz em proporcionar prazer ao ouvinte.

Por último, o etnomusicólogo e antropólogo americano Alan Merriam escreve que “[...] a música proporciona uma função de entretenimento em todas as sociedades." (1964: 223), ressaltando, porém, que se deve distinguir a utilização enquanto "puro" entretenimento - como parece ser o caso da sociedade ocidental - e entretenimento combinado com outras funções (1964).

Em relação a se portar o próprio repertório musical em todas as ocasiões, Bull relata:

Os usuários descrevem serem absorvidos pelo prazer da uma escuta ininterrupta no fluxo de suas experiências auditivas. Esses usuários preferem ouvir suas "próprias" músicas enquanto se movimentam. Eles podem ou não perceber o ambiente ao seu redor, mas na maioria das vezes só prestam atenção em suas próprias músicas. O uso de aparelhos portáteis satisfaz os desejos do usuário de ter seus sons escolhidos o acompanhando por aonde vai. $(2000,187)$

Dessa maneira, o ouvinte parece entrar em um ciclo, em que o deleite dessa escuta se torna um importante fator motivacional para que a experiência da escuta se repita.

Conclusão: A escolha do material sonoro pode ser compreendida como o prazer proporcionado ao usuário pela liberdade e controle que tem sobre o repertório a ser escutado, bem como a capacidade de transportá-lo consigo para onde for, sabendo que não haverá risco algum de ser importunado com canções indesejadas, o que também se caracteriza como uma fonte de prazer.

\section{Usos centrados na relação entre o ouvinte e o ambiente}

Fundada em quatro formas de utilização do Walkman, as funções abaixo exemplificam as maneiras que os ouvintes escolhem para modificar a interação estabelecida entre eles próprios e diversos aspectos da paisagem sonora ao seu redor.

$\underline{\text { Função }^{\circ} 2 \text { : Estetização }}$ 
$\mathrm{Na}$ estetização o ouvinte se confronta com duas maneiras de escutar enquanto se relaciona com o ambiente externo. Na primeira, ele vivencia uma situação similar a assistir um filme, ou seja, escuta sua mídia portátil enquanto observa o ambiente. A música funciona como a "trilha sonora", enquanto seus arredores como as imagens, o componente visual do filme. Na segunda, mistura-se a música escutada no Walkman com os sons do ambiente externo os quais o ouvinte é capaz de escutar mesmo através de seus fones. Ou seja, uma combinação entre as músicas do aparelho com os sons do ambiente.

A primeira situação é muito bem definida por Moebius e Michel-Annen (1994) ${ }^{35}$, ao ilustrar a comparação entre se assistir a um filme e escutar música no Walkman, ao dizer que “[...] a vida é transformada em um evento cinematográfico. O contato com a realidade diminui. Os usuários do Walkman sentem que são a audiência de um filme como voyeurs." (1994, 572).

A experiência audiovisual do cinema toma uma dimensão de realidade para o ouvinte. Assim como em uma obra audiovisual a atenção não está exclusivamente na parte sonora nem somente na visual, mas no equilíbrio entre elas, nessa experiência de escuta o usuário também não se encontra com a atenção unicamente voltada para a música, mas de alguma forma encontra um equilíbrio, tornando mais verossímil a sensação de estar fazendo parte de um filme.

O jornalista inglês Giles Smith, durante um período em que esteve doente, descreveu esse processo de escuta e as condições nas quais o vivenciou:

Um amigo me comprou um Walkman para me alegrar, o primeiro que eu tive na vida. Eu já havia eleito, mesmo antes de possuir um, que o Walkman era, depois do som embutido no interior dos carros, a mais apurada invenção do homem no século XX - o mais refinado que o homem poderia alcançar. [...] Nós podíamos ter música onde quiséssemos. Em minhas idas e vindas a infindáveis clínicas e cirurgias, eu tocava, até desgastar, um velho cassete da inefavelmente empolgante 'Let's hear it for the boy', de Deniece Williams. E me sentava ali, entre meus frágeis fones de ouvido, apreciando os amigáveis e animadores assovios. Eu olhava para fora da janela do ônibus e o mundo se transformava em um filme, o que não é a perspectiva que você quer a todos os instantes, talvez, mas nesse momento parecia maravilhosamente intrigante. (SMITH, 1995: 152).

\footnotetext{
${ }^{35}$ A pesquisa apresenta o resultado de uma entrevista detalhada com 39 usuários assíduos de Walkman. São relatos que fundamentam a discussão dos autores, em que os participantes demonstram inúmeros sentimentos, sensações e pensamentos a partir da experiência da escuta em deslocamento.
} 
O professor de psicologia Rainer Schönhammer (1989) discorre sobre a experiência de ter a paisagem sonora deslocada da realidade visível, passando a impressão de estar dentro de um filme:

\begin{abstract}
Através do Walkman, perdemos o contato com o mundo, que subitamente se torna mudo. Ao mesmo tempo, a música que ouvimos e com a qual lidamos reestabelece nossa conexão com o mundo, mas de uma forma não convencional. O que vemos deixa de ser o que era antes. Como consequência, passamos a ver como se fosse um filme. Essa experiência se dá por causa da música, mesmo se nos esquecemos que estamos ouvindo música (como geralmente acontece quando vamos ao cinema). (1989: 141)
\end{abstract}

O compositor e escritor Daniel Barbiero (1989) contribui para essa discussão afirmando que "[...] a música se tornou a textura de background da vida cotidiana, e nós tendemos a ouvi-la como ouvimos a trilha sonora de um filme: como um suplemento à ação dentro da tela." (1989: 147).

A historiadora e escritora de viagens britânica Jan Morris também descreve sua experiência ao longo de uma de suas expedições:

Quando eu viajei pela primeira vez pela costa da Yuguslavia, de Istria para Montenegro, eu tinha acabado de adquirir uma gravação, de Vladimir Ashkenazy com a Philharmonia Orchestra, de um dos concertos para piano de Mozart, não me lembro agora qual. O movimento allegro dessa peça continha um trecho do solo tremendamente vívido, perpassando de uma ponta do piano à outra, que se repetia por várias vezes, e que combinava perfeitamente, me parecia, com a exuberante paisagem que combinava montanhas, mar e ilhas, pela qual minha BMW atravessava. (1989: 33)

Por fim, Chen (1993) descreve o relato de um de seus entrevistados acerca de uma tentativa, nesse caso proposital, de interação com o local em que se encontrava:

[...] Me encontrava sentado do lado de fora de meu apartamento observando as coisas acontecendo. Tinha meus fones de ouvido a postos, para que não ouvisse nada - apenas visse - o que acontecia. Sem ouvir nada, a não ser minha música, eu poderia tentar combinar alguma música com algum evento que ocorria ao meu redor naquela hora. (1993: 105)

Os relatos acima parecem descrever com clareza essa experiência de escuta. No primeiro o ouvinte subitamente se dá conta que parece estar fazendo parte de um filme, enquanto no segundo houve uma intenção prévia.

Em suma, enquanto pode haver a intenção do ouvinte em escolher uma música que pareça adequada ao ambiente, como o relatado por Chen, o oposto também pode ocorrer, como a descrição de Morris, em que o cenário externo parece se adequar à música escutada. 
Em ambas as situações o Walkman foi o instrumento gerador da sensação de se fazer parte de um filme, proporcionando a trilha adequada para tal experiência.

A segunda forma de estetização se dá quando o ouvinte absorve a música dos fones de ouvido e os une aos sons externos, obtendo uma nova paisagem sonora, resultado dessa colaboração sonora mútua. É válido ressaltar o fato de que nesse caso o visual não tem muito impacto, mas apenas os sons. Assim, o ouvinte não tem sua atenção voltada para uma experiência audiovisual, como no primeiro caso, mas somente sonora, baseada não nas imagens externas, mas na sua paisagem sonora do local.

O jornalista e editor Steve Connor (1999) aborda essa temática ao afirmar:

No Walkman nós temos um encontro perfeitamente comum e frequente do impulso rumo à perfeição técnica absoluta que encontramos na tecnologia do $\mathrm{CD}$, na qual o que ouvimos nunca foi presente no 'aqui e agora' - é um som puramente artificial - e a estética de John Cage, que via na música uma exposição ao 'aqui e agora', uma chance de deixar acontecer o que acontecer... (1999: 308)

Para Connor, a escuta era a combinação de duas fontes sonoras: a primeira vinda diretamente de seus fones de ouvido, e a segunda dos ruídos que formavam a paisagem sonora externa. E essa síntese era viabilizada pelo Walkman.

A obra 4'33', de John Cage (1952) ${ }^{36}$ 37, era um convite aos expectadores a se atentarem aos sons que os circundavam, de maneira que a música seria composta naquele momento pelos ruídos ambientes da própria plateia. De acordo com Connor, os sons ambientes, assimilados juntamente com a música do Walkman, pode fornecer uma satisfatória e proveitosa forma de se escutar. O ouvinte tem apenas uma parte do material pré-definida e sob seu controle, ficando a outra parte indeterminada, e justamente essa sobreposição - da música com sons randômicos do exterior - pode ser o fator determinante do prazer da escuta.

Conclusão: A estetização se resume a duas práticas de escuta: a primeira em que o ouvinte se utiliza da música como trilha sonora dos estímulos visuais do ambiente externo, se sentindo parte do casting dessa obra, e a segunda, em que o ouvinte mescla o material sonoro

\footnotetext{
${ }^{36}$ Recentemente foi lançado um aplicativo para iPhone da obra 4'33", sob o anúncio: "4'33" foi a música mais polêmica e ousada de John Cage, e agora pode ser interpretada por vocêe!". A proposta é o ouvinte ativar o aplicativo e gravar a paisagem sonora do ambiente em que se encontra, tornando aquela sonoridade sua composição. Uma das funções do aplicativo é o intercâmbio de músicas entre ouvintes do mundo todo, permitindo que um ouça a música - paisagem sonora - do outro. Além disso, o aplicativo traz um bônus, que é a gravação da paisagem sonora do último apartamento em que viveu John Cage, em Nova York. Informações disponíveis em: http://johncage.org/4_33.html. Consulta em: 16 jun. 2014.

${ }^{37}$ A música também se encontra à venda pelo iTunes por U\$0.99, inclusive com a possibilidade de se escutar uma prévia antes da aquisição. Disponível em: https:/itunes.apple.com/br/album/433/id406490689. Consulta em 16 jun. 2014.
} 
proveniente de sua mídia portátil com os estímulos sonoros (e não visuais) do ambiente que o circunda, criando assim uma justaposição sonora sempre inesperada, resultante dessa interação.

\section{$\underline{\text { Função } n^{\circ} \text { 3: Controle ambiental }}$}

Nessa categoria o ouvinte se utiliza de seu Walkman como substituição dos sons externos que considera inoportunos e não-prazerosos. Como resultado, o ouvinte tem sua atenção centrada apenas na música, e não na paisagem sonora circundante.

O escritor e colunista americano Evan Eisenberg discorre minuciosamente sobre o impacto cultural da música gravada em seu primeiro livro, intitulado The Recording Angel (1988). O autor diferencia a experiência de se escutar uma música pela apreciação musical dela mesma - ou ouvi-la por si só e por seu valor artístico passivo de apreciação - ou ouvir música objetivando controlar o ambiente sônico ao redor. Diz Eisenberg:

A cidade não é lugar de se escutar música. Metade do tempo o ouvinte termina por usá-la como escudo contra o som das outras pessoas. A música se torna um substituto do silêncio. (1998: 84)

Ou seja, Eisenberg acredita que a utilização da música como escudo contra os barulhos alheios caracteriza uma escuta bastante diferente de quando há silêncio e o ouvinte consegue apreciar a música em um ambiente desprovido de elementos sonoros intrusivos e distrativos.

Eisenberg também reafirma as afirmações de Schafer (1992), quando este descreve as paisagens sonoras hi fi e low fi. Para Schafer a cidade é um ambiente low fi, ruidoso, em que demasiadas informações sonoras incessantemente atingem nossos ouvidos em várias camadas de frequência simultâneas, nos impossibilitando de uma escuta detalhada e clara. Eisenberg complementa essa afirmação ao dizer que a cidade (entenda-se metrópole) não seria, pois, o lugar ideal para uma escuta clara, uma vez que portaria perturbações sonoras demais para que o ouvinte se concentre no material sonoro, deixando de apreciá-lo e passando a defender-se desses estímulos.

Seria o caso de um ouvinte em um metrô. Em recente pesquisa, publicada pelo jornalista João Varella ${ }^{38}$, a Associação Brasileira de Otorrinolaringologia e Cirurgia Cérvico-Facial ${ }^{39}$ comprovou a alta perturbação sonoros a que os usuários do metrô de São

\footnotetext{
${ }^{38}$ Matéria online publicada em 21/06/2010, intitulada Barulho em metrô de São Paulo chega a ter intensidade de show de rock. Disponível em <http://noticias.r7.com/sao-paulo/noticias/r7-testou-barulho-no-metro-de-sp-chegaa-ter-intensidade-de-show-de-rock-20100621.html>. Consulta em 28 mar. 2014.

${ }^{39}$ Cf.<http://www.sborl.org.br/>
} 
Paulo estão expostos diariamente. Em alguns trechos o ruído chegou a 108 dB, o equivalente a um show de uma banda de rock. Em outros, o ruído não baixou dos $98 \mathrm{~dB}$, que se equipara com o barulho de uma serra elétrica ou furadeira.

Pensemos em um ouvinte portando um Walkman ou qualquer outra mídia portátil dentro desse ambiente. Não seria surpreendente esse usuário se utilizar da música como defesa, o escudo que Eisenberg (1998) menciona, contra a agressão sonora externa, aumentando o volume de sua mídia. De fato, é o que a pesquisa nos metrôs de São Paulo revelou. Um dos entrevistados menciona que para driblar os altos ruídos escuta música eletrônica com fones de ouvido conectados em seu smartphone. "Só consigo ouvir no último volume", afirma (VARELLA, 2010).

Considerando que um metrô pode apresentar radicais oscilações de intensidade sonora, partindo do extremo silencio (parado na estação) ao barulho máximo (em alta velocidade), é compreensível a dificuldade do ouvinte em apreciar a música dos fones de ouvido. A partir dessa dificuldade ele inicia uma espécie de guerra sonora, com o objetivo que seu som privado sempre vença o externo em volume, sendo prejudicado tanto em seu aspecto físico/auditivo, quanto em seu processo de escuta, resultando em uma possível ausência de apreciação física e também musical.

A fim de que o ouvinte tenha maior controle na redução do barulho externo, podendo focar sua atenção exclusivamente no material sonoro de sua mídia, algumas empresas ${ }^{40}$, como a japonesa Audio-Technica ${ }^{41}$, desenvolveram fones de ouvido com o recurso de noisecancelling ${ }^{42}$. Exemplifiquemos com a descrição de um dos produtos da empresa, os fones de ouvido ATH-ANC9 QuietPoint.

De acordo com a fabricante, esses fones foram desenvolvidos com a finalidade de "prover uma confortável experiência de escuta em áreas de grande concentração de ruídos." Prometendo redução de até $95 \%$ dos ruídos ambientes externos, o artefato possui três modos de funcionamento: o primeiro, "ideal para aviões, trens e ônibus", o segundo "desenvolvido especificamente para utilização em escritórios ruidosos ou lugares de muita lotação", e um terceiro que "cria um ambiente puro e aconchegante, ideal para estudo". Os três modos

\footnotetext{
${ }^{40}$ Além da mencionada Audio-Technica, a empresa Bose também oferece fones de ouvido com a mesma tecnologia noise cancelling. Informações podem ser encontradas no website oficial da empresa: <http://www.bose.com/controller?url=/shop_online/headphones/noise_cancelling_headphones/index.jsp.> Consulta em 15 jun. 2014

${ }^{41} \mathrm{http}: / /$ www.audio-technica.com. Empresa japonesa especializada em produtos de áudio, como microfones, fones de ouvido, entre outros.

${ }^{42}$ Active Noise Control (ANC) é um método utilizado para se reduzir a interferência de sons não desejados a partir da adição de uma segunda onda sonora contrária à principal, a fim de que o encontro de ambas resulte em um cancelamento, ou anulação da onda principal.
} 
trabalham através do cancelamento de faixas de frequências diferentes, adaptadas de acordo com os sons ambientes. No primeiro modo de funcionamento, os fones cancelam as frequências graves, predominantes em aviões e trens, enquanto no segundo modo as frequências canceladas são as médias, relacionadas à região da fala, sendo assim apropriado para ambientes de muita concentração e movimentação humana ${ }^{43}$.

O terceiro modo seria uma utilização não muito rotineira dos fones de ouvido, em que o usuário não o usaria juntamente com uma mídia portátil, mas somente o fone desconectado de qualquer aparelho, visando simplesmente criar um ambiente silencioso para que se concentre em tarefas outras que não a escuta musical, como o estudo ou a leitura. Tal comportamento será abordado com maior ênfase no capítulo seguinte desse trabalho.

O professor japonês Shuhei Hosokawa cunhou a expressão Walkman effect em seu artigo de mesmo nome no ano de 1984. O termo se refere a como a música escutada por fones de ouvido confere ao ouvinte o poder de controlar o ambiente externo. Obviamente a expressão se referia especificamente ao aparelho Walkman lançado pela Sony. No entanto, as ideias apresentadas, bem como suas conclusões ainda são extremamente relevantes e atuais no cenário contemporâneo das mídias portáteis.

Hosokawa (1984) acredita que a escuta em deslocamento se caracteriza como um ato inerente de solipsismo - uma concepção filosófica em que nada existe além daquilo que experimento. Para o autor, os ouvintes ignoram o conteúdo sonoro alheio a seus fones de ouvido, incluindo os necessários para a interação social, preferindo, ao invés disso, sua própria paisagem sonora previamente escolhida, transmitida diretamente através do Walkman.

Chambers (1994) também compreende a tentativa do ouvinte em anular os estímulos externos, porém, ao contrário de Hosokawa, não crê que seja possível uma total anulação. Ele propõe que "[...] cada ouvinte seleciona e rearranja a paisagem sonora e, construindo um diálogo com ela, deixa um rastro nessa interação" (1994: 50). Chambers fala de diálogo, indicando que existe uma interação de ação e reação, pergunta e resposta, entre o ouvinte e o ambiente, de forma que apesar de parecer isolado, em algum grau este está constantemente estabelecendo vínculos com seu ambiente.

Bull (2000), quando se referindo à motivação do ouvinte em bloquear os sons externos, prossegue afirmando:

Os usuários podem ter o desejo de bloquear qualquer som externo que eles venham a ouvir na rua ou em qualquer outro lugar. A intrusão de

\footnotetext{
${ }^{43}$ As citações apresentadas, bem como os demais dados técnicos relacionados ao produto foram retirados da página oficial da empresa. Disponível em: http://www.audio-technica.com/cms/headphones/939a5e9985fc5d2c/. Consulta: 28 mai. 2014.
} 
qualquer espécie de som localizado no espaço é indesejada. Eles buscam, através do uso (do Walkman), as experiências sonoras audíveis involuntárias em espaços públicos, pelas suas próprias paisagens sonoras posicionadas diretamente entre seus ouvidos. (2000: 186)

A professora de História Cultural Judith Williamson, na obra Consuming Passions (1988), quando discorrendo sobre a temática do controle sonoro ambiental amparado nas mídias portáteis, nesse caso o Walkman, traz outro interessante e relevante fator de análise para a reflexão:

O Walkman tenta negar a imprevisibilidade: você nunca saberá o que vai ouvir em um ônibus ou nas ruas, mas tal caminhante é amortecido contra o inesperado - um aparente triunfo do controle individual sobre a espontaneidade social. (1988: 210)

Assim como John Cage, Williamson valoriza a espontaneidade dos sons e das paisagens sonoras. Estariam as mídias portáteis nos privando da experiência de perceber e participar dos sons que nos circundam, uma vez que toda a natureza aleatória de tais sonoridades é reprimida pelo controle absoluto de um indivíduo com fones de ouvido?

Chambers (1994) também contribui para essa discussão, observando:

[...] se o Walkman até agora representa o que há de mais avançado na arte de trânsito, ele também representa o maior significado musical na mediação com o ambiente. Ele permite a possibilidade, ainda que frágil e transitória, da imposição de sua paisagem sonora no ambiente externo, assim domesticando o mundo externo: por um momento tudo pode ser reduzido aos botões STOP/START, FAST FORWARD, PAUSE e REWIND. (1994, 51).

Todavia, Chambers não trata desse controle ambiental como puramente prejudicial, mas propõe a ideia de que o controle de substituição das paisagens sonoras pode também beneficiar o ouvinte, sendo capaz de influenciar seus sentimentos, de maneira que através de tal recurso ele consiga se sentir confortável em diversos ambientes diferentes, que em outro contexto o fariam se sentir incomodado.

Expandindo ainda mais a reflexão sobre a função do controle ambiental, surge outro elemento sugestivo para análise, que é a "localização" da música escutada através das mídias portáteis.

Um ouvinte, ao utilizar fones de ouvido, passa a ter a impressão que a música não é um estímulo externo, mas interno. Talvez por estar desprovido do apoio visual da fonte sonora, este pode passar a entender a música como um fenômeno interno, dando à escuta uma nova perspectiva, a partir de seu ponto de vista, sobre a qual escrevem Moebius e Annen: 
[...] os sons cotidianos, os sons ambientes, são suprimidos. Os usuários do Walkman sentem a música como se ela estivesse dentro deles. Não há uma fonte sonora localizável, não existem grandes altofalantes, não há instrumentistas. A música parece estar dentro de suas cabeças, proporcionando uma sensação de preenchimento. A sensação da escuta é inundada com a música, e uma comunicação normal pode se tornar impossível. O contato com o ambiente, então, acontece através dos olhos, e não dos ouvidos. O significado da visão aumenta, a partir do ponto de vista subjetivo do ouvinte de Walkman. (1994: 572)

Essa descrição parece mostrar com clareza a importância dos fones de ouvido associados às mídias portáteis. Injetando o som diretamente dentro dos ouvidos, proporciona ao ouvinte um estado de "inundação" musical, contribuindo para que os sons ambientes sejam ignorados e os sons provenientes de sua mídia supervalorizados.

Conclusão: Em suma, a função de controle ambiental é a substituição dos sons ambientes pelos da mídia portátil, diminuindo a atividade de escuta do ouvinte frente aos estímulos externos e mergulhando-o nos estímulos internos de sua própria paisagem sonora.

\section{Função nº 4: Demarcação de Território}

A demarcação de território pode ser entendida como uma adaptação, ou até extensão do controle ambiental. O ouvinte que carrega seu aparelho, quando desconfortável em ambientes superlotados ou ruidosos demais, se utiliza do Walkman tratando-o como uma espécie de livro ou jornal, de maneira que se mantenha entretido e "se esqueça" de que está ali. Em outras palavras, o ouvinte sente que o Walkman serve como uma ferramenta capaz de "removê-lo" daquele ambiente sonoro que o incomoda.

Enquanto no controle ambiental o ouvinte se esforça para que sua mídia vença as sonoridades externas, lutando para anulá-las, na demarcação de território a função da música é a de entretê-lo de maneira que ele deixe de reparar nos ruídos que interferem em sua escuta, "transportando-o" para outro lugar.

Uma das ferramentas apropriadas para se alcançar esse objetivo é o estabelecimento de limites, ou fronteiras, entre a paisagem sonora externa e o ambiente sonoro do ouvinte. Gary Gumpert (1987), professor e presidente da Urban Communication Foundation, desenvolveu os conceitos de espaço acústico e barreira sonora ${ }^{44}$ para se referir à demarcação de fronteiras

\footnotetext{
${ }^{44}$ Acoustic space e Wall of sound, no original.
} 
entre o espaço sonoro do ouvinte e externo. Gumpert define a barreira sonora como "o senso de espaço acústico que cerca a cada um de nós" (1987: 87). É como se existisse, cercando cada indivíduo, uma espécie de redoma, ou bolha, na qual se define e na qual se limita o espaço sonoro daquele ouvinte. E cada pessoa, para onde vai, carrega consigo seu espaço sonoro.

Para Gumpert a demarcação desse espaço pessoal é fundada em uma prática há muito já existente no reino animal, na qual sinais sonoros audíveis são gerados como forma de marcação territorial. Uma canção de um grilo, ou os brados de um gorila são exemplos disso. Para o autor, a música gravada proporciona uma capacidade similar. Assim ele observa:
Muitos de nós nos cercamos e nos protegemos com barreiras sonoras quando estamos envolvidos em uma atividade pública. Uma bicicleta é adornada por um pequeno rádio. Um picnic inclui um pequeno rádio portátil sobre a toalha. A distância entre as toalhas estendidas em um dia de praia cheia não é somente determinada pela distância pessoal, mas por zonas de música. (1987: 87)

Ou seja, para Gumpert as pessoas determinam seu espaço não somente pela presença física, mas também por aspectos sonoros. No momento em que se colocam os fones de ouvido, o usuário do Walkman cria seu espaço acústico, delimitando fronteiras entre seu espaço privado e o público, exterior.

Eisenberg (1988), assim como Moebius e Annen (1994), concorda que o ouvinte pode se envolver a tal ponto de se sentir submerso na música que ouve, afirmando que os fones de ouvido "dão a impressão que o sujeito escapa da voracidade urbana, porque o indivíduo se encontra dentro da música" (1994: 44-45). Mais uma vez, dois ambientes distintos são determinados, havendo entre eles uma linha, ou um espaço sonoro, que os separa.

No entanto, o quanto o ouvinte consegue controlar ou mesmo se "ausentar" do ambiente em que se encontra através das mídias portáteis não é mensurável, tampouco unanimidade.

Autores como Eric Adler (1999) e Keith Negus (1992) acreditam que a mídia portátil seja capaz de isolar completamente o ouvinte do ambiente externo, eliminando todo e qualquer tipo de interação com pessoas ou objetos ao redor. Tal perspectiva já não soa tão convincente para Chambers (1994), que advoga ser inviável um isolamento completo. Mais que isso, o autor acredita que qualquer suposição de isolamento é falsa, e que o uso do Walkman em um ambiente público simplesmente comprova uma interação entre o ouvinte e seus arredores. 
Adler (1999), quando abordando o Walkman, fala de uma "escuta solitária", assim como Negus (1992), que a trata como "solidão móvel". Para ambos, os fones de ouvido são inteiramente capazes de segregar o ouvinte, como na seguinte afirmação:

O Walkman possibilita seu usuário a carregar a música por todos os lugares que ele for, e excluir o mundo externo e os demais seres humanos. Isso possibilita os japoneses a lidarem com metrôs lotados, mas o Walkman induz a uma sensação de solipsismo. Ele isola os indivíduos do mundo através da música. (NEGUS, 1992: 35)

Negus é incisivo ao tratar o isolamento proporcionado pelo Walkman. Porém, deve-se considerar o possível paradoxo encontrado em tal suposição de isolamento. Ora, se a música é a companhia constante desse ouvinte, e o isolamento está fundado no estar só, não seria equivocado supor que alguém que esteja ouvindo música esteja só? Talvez o isolamento se restrinja à interação com os demais presentes no ambiente, mas parece discutível o real nível de isolamento do indivíduo. Pensemos em um indivíduo em uma sala de espera que, movido pelo som que escuta em seu fone, bate com os pés no chão no compasso da canção ou bate com as mãos nas coxas no ritmo da música, de maneira audível aos demais presentes no local, incomodando-os. Mesmo se considerarmos que esse indivíduo está “ausente” ou indisponível para interações sociais, não estaria ele de alguma forma interagindo socialmente, ao passo que está gerando impaciência ou raiva nos indivíduos ao redor pelo excesso de barulho?

Chambers (1994), ao contrário, prefere falar de uma "experiência privada" (1994: 49), na qual se observa algum grau de envolvimento entre as partes, comparando a escuta mediada por um Walkman à "visão com óculos de sol” (1994: 50). Em ambas o indivíduo estaria estabelecendo uma linha divisória entre o ambiente enquanto simultaneamente reafirmando seu contato com o mesmo.

$\mathrm{Na}$ demarcação de territórios sonoros, parece estar em voga a questão da privacidade. O ouvinte precisa de certa distância dos elementos de distração, e por isso a necessidade de se criar essa redoma. Aqui a experiência da escuta requer concentração, caso contrário o ouvinte não será capaz de esquecer o desconforto do ambiente em que se encontra, inviabilizando a eficácia dessa função da escuta móvel.

A professora de Comunicação e jornalista Rebecca Lind diz que "[...] o Walkman lhe permite criar seu espaço privado" (1989: 59), espaço esse que caracteriza justamente o objetivo de alguém que se equipa com tal aparato. É imerso nessa privacidade que os demais processos de "ausência", objetivado na demarcação territorial, acontece.

Ao tratar da privacidade, Chen (1993) compara o ato de se ouvir Walkman com o de ler um livro - ambas as atividades que requerem certo isolamento e concentração: 
Ainda que ler se caracterize como um ato individual, o ato da leitura não previne intrusões de terceiros. Escutar um Walkman, ao minimizar a escuta das fontes sonoras externas, envolvendo e preenchendo o ouvinte com ritmo, melodias, imagens e emoções, pode de maneira mais completa desligar o ouvinte do ambiente externo. (1993: 93)

Na sequência Chen trabalha sobre o conceito de narcisismo, definindo-o como "um estado de auto-absorção no qual o indivíduo se retira do ambiente externo, desligando-se das atividades sociais, sendo indiferente aos demais." (1993: 95). Essa definição está diretamente associada à demarcação de território, e sem se preocupar com o grau de isolamento proporcionado pelos fones de ouvido (se total ou parcial), repousa no fundamental: a transposição do foco de atenção do ouvinte para o material sonoro. A autora então prossegue:

O Walkman permite aos ouvintes individuais a apreciação privada das sensações viscerais trazidas pela música. Conforme o indivíduo se sacia na experiência das sensações privadas, ele é completamente envolvido em seu próprio universo. (1993: 95).

Chen, com essa afirmação, reconhece que a música é capaz de se tornar o foco da atenção de um ouvinte a ponto de transportá-lo para fora do espaço incômodo, ou seja, removê-lo do ambiente que o perturba.

Conclusão: A demarcação de território é uma ferramenta facilitadora que permite ao ouvinte atravessar de maneira menos traumática lugares superlotados, incômodos ou ruidosos, enfim, ambientes opressores. Como uma extensão da função de controle ambiental, é composta de dois elementos: primeiro, a barreira sonora entre os sons externos e o ambiente privado dos fones de ouvido. E segundo pela capacidade da mídia portátil de captar a atenção do usuário de forma a distraí-lo da perturbação sonora que o rodeia, e que seria o foco de sua atenção na ausência do aparato.

\section{$\underline{\text { Função } n^{\circ} \text { 5: Mediação interpessoal }}$}

A mediação interpessoal se refere à tentativa de limitação de interação do ouvinte com o ambiente ao seu redor, porém nesse caso o elemento principal a ser evitado não são os ruídos em si, mas as pessoas, e qualquer tipo de interação com as mesmas. 
Essa função pode ser compreendida em três modos: na disputa de volumes ${ }^{45}$ do ouvinte com o ambiente externo, na introspecção do ouvinte com sua mídia, e no poder da visibilidade do aparelho. O primeiro ocorre quando a música do Walkman vence (em volume) os sons externos, impedindo-o de ouvir as pessoas ao redor, limitando assim as tentativas dessas de captar sua atenção. O segundo é quando o ouvinte se encontra dominado pela sua paisagem sonora particular, e distraído, perde as oportunidades de interação com os demais. E o terceiro modo compreende o papel do aparato em si mesmo, como objeto de intimidação frente às atividades interpessoais. A utilização pública e visível de uma mídia portátil sugere aos demais que aquela pessoa não deseja ou não está aberta para interações, fazendo-os abandonar qualquer iniciativa, já prevendo um possível fracasso nessa tentativa de interação.

O primeiro modo já foi, em partes, discutido nas duas funções anteriores, o controle ambiental e a demarcação de fronteiras. A partir de um controle ambiental no qual o ouvinte busca se isolar do ambiente sonoro externo, demarcando seu território, e distinguindo-o do alheio, tem-se como uma das consequências a limitação das atividades de interação. Vencendo a luta de volume entre os ambientes, o usuário não dá brechas para que sua atenção seja chamada por alguém de fora. Mesmo com algum esforço, os demais correm o risco de serem ignorados, principalmente se a tentativa de interação for baseada em sons.

Supondo que o ouvinte esteja escutando sua mídia portátil com o olhar direcionado para o chão - e com um volume maior que o externo - é pouco provável que um terceiro tenha sucesso chamando esse ouvinte pelo nome, ou através de comunicação verbal. A atenção poderia, no entanto, ser obtida caso o terceiro esteja dentro do campo visual do ouvinte, articulando através de gestos.

Outro aspecto a se considerar é que, por mais que o ouvinte não deseje estabelecer nenhum tipo de vínculo com os demais, isso não pode ser completamente evitado. Mesmo que apenas fisicamente, ele está ali, e isso seria o suficiente para proporcionar o início de algum tipo de relação.

O segundo modo se resume a uma consequência da função de demarcação territorial. O ouvinte, ansioso em entreter-se inteiramente com sua própria música, em sua experiência narcisista, como diria Chen (1993), acaba por distrair-se a ponto de perder oportunidades de interação com terceiros, que podem passar despercebidas de sua atenção. Se isso o incomoda ou não, seria motivo de outra pesquisa, mas é fato que o espectro de atividade interpessoal

\footnotetext{
${ }^{45}$ Ao termo volume aplica-se aqui a utilização popular (não-científica), ou seja, ao parâmetro de intensidade sonora.
} 
desse usuário é diminuído, ao passo que não engloba uma iniciativa de envolvimento com os demais, ou seja, uma atitude ativa de busca por interação.

Em relação ao segundo modo de relação interpessoal, Chen (1993) conclui:

O uso do Walkman cria uma segregação social, em que o fechamento do ambiente musical diminui a probabilidade de uma interação social. A tendência anti-social permite ao indivíduo se utilizar do aparelho para criar um mundo privado invisível externo ao ambiente social existente, segregando-o dos demais. (1993: 108)

O terceiro modo se fundamenta no papel do próprio aparato tecnológico como agente limitador de interações interpessoais.

Quando se percebe algum indivíduo carregando sua mídia portátil e usando fones de ouvido, naturalmente ele passa a ser considerado indisponível para uma relação direta imediata. A visibilidade do aparelho por si só já estabelece um limite, e especialmente os fones de ouvido já carregam a informação de que aquele indivíduo deseja privacidade, e está com a atenção voltada para outra atividade, nesse caso, a escuta. O transeunte então procura por outra pessoa desprovida de fones de ouvido para interagir.

Devemos considerar que a maioria dos usuários tem plena consciência de que a partir do momento em que cobrem os ouvidos com um fone se tornam um tanto inacessíveis para relacionarem-se publicamente. Não à toa que tal atitude, em muitos casos, são propositais, e os usuários tiram proveito disso justamente para evitarem contato externo. É o caso de personalidades e pessoas requisitadas socialmente.

Personalidades da televisão, cinema ou esporte são flagrados, em grande parte de suas aparições públicas, usando fones de ouvido. Sejam seleções de futebol fazendo o translado entre o ônibus e a entrada do hotel, ou cantores saindo das Limousines para o backstage, os fones são presença marcante. Normalmente devido à presença massiva de jornalistas, paparazzi e da mídia em geral, esses indivíduos recorrem a ferramentas que minimizem a necessidade de interação, ou até a possibilidade dela ocorrer. No caso de um time de futebol, o membro que, em meio a vários outros com fones de ouvido, não estiver utilizando um, certamente chamará a atenção da imprensa, pois passará a impressão de estar disponível para o estabelecimento de relações interpessoais, enquanto seus colegas estão envolvidos em outra atividade à qual não desejam ser importunados.

Parece interessante também o fato de que por vezes o usuário pode sequer estar ouvindo algo, mas somente fingindo, apenas para limitar a interação com o ambiente. Tal comportamento pode ocorrer quando não se quer ser perturbado ou quando prevalece um desconforto em estar presente em um local não desejado, e a mídia então é utilizada como 
uma ferramenta de fuga das relações possíveis de ali acontecerem. No caso do Walkman, o ouvinte pode "[...] até mesmo fingir que ouve algo" (BULL 2000: 190) para se esquivar da interação. Porém, essa situação do "fingir" não se aplica somente ao Walkman, mas a todos os gadjets portáteis, dos tablets aos smartphones.

O indivíduo presente em uma festa a qual não desejava ir, em uma sala de espera com estranhos ou em um elevador, para evitar ter que iniciar algum tipo de interação desconfortável, prontamente saca de seu bolso um smartphone e finge estar trabalhando em uma atividade que exige alta concentração, podendo inclusive alterar sua expressão facial para um semblante de preocupação, tudo isso enquanto vagarosamente repassa a vista sobre sua lista de contatos.

Gumpert (1987), tratando desse modo de relacionamento, observa:

Os fones de ouvido de um Walkman demarcam um território acústico o qual não deve ser adentrado sem permissão e no qual interações com pessoas externas são restritas. A barreira sonora é silenciosa, mas muito clara. A presença do Walkman torna o indivíduo externo invisível - um sentimento estranho e desconfortável. É igualmente estranho testemunhar alguém girando e batendo os pés sobre uma batida imperceptível. A suspeita de um possível distúrbio mental desaparece quando são avistados os fones de ouvido, e o ouvinte caminha e corre compassado com a batida de sua fita. (1987: 91)

Acerca da impossibilidade do ouvinte em manter vínculo com sua música e ao mesmo tempo com as pessoas ao redor, Lind (1989) diz que "um indivíduo consegue ou utilizar sua mídia portátil ou interagir com os demais. A atitude perante essas atividades parece ser mutuamente excludente" (1989: 101).

Finalizando a discussão, Bull aponta que os ouvintes de Walkman:

[...] sentem que as outras pessoas não os incomodam tanto, pois eles parecem mais difíceis de aproximar. Os usuários descrevem que se sentem mais seguros em público quando se utilizando de suas mídias particulares. Essas mídias são como placas móveis de 'Não perturbe'. Elas também são uma maneira eficaz para controlar os modos e a natureza do contato com os outros. (2000: 189)

Conclusão: A mediação interpessoal se faz a partir da utilização do Walkman ou qualquer outra mídia portátil com a finalidade de controlar o grau de interação com as pessoas ao redor do ouvinte. Através do bloqueio aos estímulos sonoros externos, à distração do ouvinte fechado em sua escuta e à imponência visual do aparato em si, o usuário consegue estabelecer limites com o mundo exterior. Por vezes essas consequências não são de todo 
intencionais, mas frequentemente os aparelhos são utilizados com total consciência, como uma ferramenta de controle ao grau de convivência e socialização que se pretende ter.

\section{Usos em que o ouvinte centra a atenção em si próprio}

As cinco funções analisadas a seguir trabalham sobre a utilização das mídias portáteis com a finalidade do ouvinte gerenciar aspectos da própria experiência de escuta.

\section{Função $n^{\circ}$ 6: Companhia}

Na companhia, o ouvinte se utiliza da música como uma companheira substituta cuja finalidade é a de aliviar sentimentos de solidão. A música escutada provê a sensação de se estar na companhia dos músicos que a executam, substituindo assim o vazio de se sentir só.

Theodor Adorno, em sua obra Philosophy of Modern Music (1973) já sugeria que a música gravada poderia estabelecer uma interação com os ouvintes solitários, ao passo que esses, ao ouvirem uma obra musical, se sentiriam na companhia de quem a toca. Assim, o autor vê a música gravada como uma forma de comunicação entre o emissor e o receptor.

Um exemplo trivial dessa forma de interação sugerida por Adorno seria o ouvinte fingir que está regendo uma orquestra, tocando bateria ou executando um solo de guitarra com os braços e pernas balançando ao vento, sobre instrumentos invisíveis ${ }^{46}$. Essa "participação" na música gravada cria a ilusão de um esforço cooperativo entre o ouvinte e o grupo musical. Ou seja, ao invés de uma interação baseada em um contato direto entre o ouvinte o grupo, como no caso de uma apresentação ao vivo, existe uma relação indireta e muito mais subjetiva quando há a mediação de reprodução sonora.

A respeito da companhia e sobre o que se refere ao grau de sociabilização do usuário de Walkman, a filósofa e musicista Kathleen Higgins observa:

A música é, por sua própria natureza, uma atividade social. Mesmo a música escutada pelos fones de ouvido de um Walkman soa como se viesse de uma realidade externa. E de fato ela vem de fora do indivíduo. Um relacionamento social entre aqueles que a produzem e os que a escutam ainda ocorre, embora altamente mediado. Além disso, acredito que a maioria dos ouvintes experimenta a música,

\footnotetext{
${ }^{46}$ Essa prática se tornou tão popular que existe, desde 1995, o Campeonato Mundial de Air Guitar, cujo slogan da competição de 2014 é "Make Air, not War". O Air Guitar nada mais é do que a prática de se "tocar" uma guitarra invisível, ou, melhor dizendo, fingir que se está tocando uma música na guitarra enquanto ela é executada nos alto-falantes. Nessa competição, a música mais bem executada e interpretada ganha a competição. Para mais informações, acessar: http://www.airguitarworldchampionships.com/
} 
mesmo quando através dos fones de ouvido, como uma forma de comunicação entre eles e os outros seres humanos. (1991: 51)

Apesar de em alguns pontos Higgins estar em sintonia com os pensamentos de Adorno, existe também uma discordância significativa, pois enquanto Adorno acredita que qualquer interação entre o ouvinte e o intérprete não passa do caráter imaginário, Higgins sugere que a música gravada facilita um relacionamento social real entre as partes.

Para Higgins, a música (ainda que mediada) se constitui como uma forma de comunicação, e que o ato de se ouvir e responder a tais estímulos constitui de fato uma forma de interação social. Adorno, mesmo reconhecendo a música como uma forma de comunicação, não vê a interação entre o ouvinte e uma música mediada como uma forma real de interação, pois para isso deveria haver alguma forma de diálogo, e o que na prática ocorre é um monólogo da música gravada.

Na prática os ouvintes não parecem titubear ao considerar a música como companhia. Muitos profissionais que trabalham sozinhos, como porteiros, motoristas e empregados domésticos, têm no rádio, na televisão (muitas vezes utilizadas como rádios, apenas pelo som) ou nos smartphones sua fonte de companhia. Seja ouvindo música ou notícias, o primordial parece ser não o conteúdo transmitido, mas a presença do outro, uma voz ao lado, que extirpa o sentimento de solidão. O mesmo ocorre com os indivíduos que quando sozinhos ligam a televisão, mesmo sem interesse direto na programação. As vozes dentro do ambiente, nesse caso somadas às imagens de outros indivíduos, parecem ser motivo de consolo, consequentemente tornando essa companhia agradável.

Conclusão: A companhia é a utilização da música como substituta da presença física de alguém, de forma a reduzir o sentimento de solidão do ouvinte. Ao escutar uma canção, o indivíduo exerceria alguma espécie de interação com o material ouvido, mais especificamente com os intérpretes, de forma a se sentir parte do grupo, da banda ou da orquestra. Esse diálogo pode ser manifestado de diversas formas, seja através de um discreto consolo interior ou do balançar dos membros do corpo de maneira ativa e ritmada com a música.

Seja como for, o ouvinte contemporâneo pede por companhia, ao se exercitar individualmente, viajar de avião, ônibus, trabalhar ou mesmo caminhar pela cidade, dialogando sem usar as palavras. 
A memória auditiva é a capacidade de se evocar memórias a partir da música que se escuta. Essa função não é exclusiva do Walkman ou qualquer outra mídia portátil, mas está muito mais intimamente ligada à música em si do que a seu aparato de reprodução, evocando todo o poder semiótico dessa linguagem e traduzindo-o em sentimentos e sensações.

Os pensamentos, sentimentos e emoções não são direcionados a terceiros, nem aos que circundam fisicamente o ouvinte, tampouco são evocações imediatas, mas memórias mais significativas do passado.

Conforme observa Adorno (2011) na obra Introdução à Sociologia da Música, a música por si só não estabelece vínculo algum com acontecimentos extramusicais. É o ouvinte que atribui tais laços, passando a fornecer para a música em questão essa funcionalidade e algum significado. Assim, uma música que toca profundamente um ouvinte pode ser completamente ignorada e sem valor para outro. Tal é a base da teoria de escuta de Ola Stockfelt (2004). Enquanto uma obra de Debussy pode levar um determinado indivíduo ao sono, pode irritar e soar amargo aos ouvidos de outro. Da mesma forma, enquanto sons de natureza ${ }^{47}$ são comercializados sob o rótulo de relaxantes, não seria essa a sensação de alguém que tenha ficado preso em um cativeiro em meio a uma floresta, ou um sujeito atacado por um predador na selva.

Portanto, a memória auditiva se fixa na evocação de associações com eventos passados, não necessariamente determinando que tais evocações sejam boas ou ruins. A memória trazida à tona foge do controle do ouvinte, restando-lhe apenas o domínio sobre como agir perante os pensamentos, sentimentos e sensações emergidos.

Viktor Frankl, renomado psiquiatra austríaco do século XX, relembra em seu livro Em busca de um sentido (2009) as marcas de horror deixadas durante sua prisão no campo de concentração de Auschwitz, no período do domínio nazista. Entre as duras lembranças, Frankl descreve algumas particularidades relacionadas aos sons que acompanhavam sua trajetória. Assim diz:

[...] em cada vagão do trem se estiram 80 pessoas sobre sua bagagem (seus últimos haveres). As mochilas, bolsas etc. empilhadas quase impedem a visão pelas janelas, deixando livre apenas um último vão na parte superior. [...] Todos achávamos que o transporte se dirigia para alguma fábrica de armamentos, onde nos usariam para trabalhos forçados. Aparentemente o trem pára em algum lugar no meio da linha: ninguém sabe ao certo se ainda estamos na Silésia ou já na

\footnotetext{
${ }^{47}$ Apenas como exemplificação, ver o CD intitulado Sons da Natureza: Tranquilidade, comercializado online através do site: <http://www.americanas.com.br/produto/5465346/cd-sons-da-natureza-tranquilidade>, ou o website <http://naturesounds.in/> - que traz como apresentação principal da página o mote Peaceful sounds for a peaceful day.- no qual o usuário pode escolher entre inúmeros sons (chuva, vento, animais etc) e ouvir através do próprio site por quanto tempo desejar.
} 
Polônia. O apito estridente da locomotiva causa arrepios, ecoando como um grito de socorro ante o pressentimento daquela massa de gente personificada pela máquina e por esta conduzida rumo a uma grande desgraça. (2009: 22)

E prossegue o relato de sua chegada em Auschwitz:

Aqui e ali se ouve um apito de comando - e ninguém sabe para quê. Em alguns de nós, o terror fica estampado no rosto. [...] Finalmente chegamos à estação de desembarque. Lá fora, nenhuma movimentação, ainda. De repente, brados de comando daquele jeito peculiar - estridente e rude - que de agora em diante ouviríamos sempre de novo em todos os campos de concentração, cujo som é semelhante ao último berro de um homem assassinado, com uma diferença: o som também é rouco e fanhoso, como se saísse da garganta de um homem que tem que gritar constantemente assim porque está sendo constantemente assassinado. (2009: 23)

Considerando que a primeira edição do livro foi lançada no ano de 1984, ou seja, aproximadamente quarenta anos após sua saída de Auschwitz, percebe-se como a memória auditiva é significante, podendo-nos fazer reviver experiências há muito idas, e nesse caso, que mereciam ser esquecidas.

Outro exemplo similar é relatado no documentário Wartorn $1861-2010(2010){ }^{48}$, o qual apresenta as dificuldades cotidianas de veteranos de guerras. Com o foco no alarmante índice de TEPT (Transtorno de Estresse Pós-Traumático) encontrado nos soldados que retornam dos campos de batalha, o documentário apresenta a triste realidade de veteranos que veem em atividades simples, como ir ao supermercado com a família ou a uma apresentação escolar desafios quase impossíveis de serem cumpridos. Um dos entrevistados relata que, de forma especial, o dia da independência dos Estados Unidos, comemorado em 04 de julho, é uma das piores datas do ano. Uma das maiores festividades do país, esse dia é celebrado com fogos de artifício de longa duração. Ao ouvir os artefatos explodindo no ar, o ex-combatente automaticamente é remetido ao som de tiros, e levado novamente ao meio do combate que viveu algum tempo antes. $\mathrm{O}$ estresse toma proporções tão grandes que, não somente ele, mas vários veteranos relatam que durante os fogos de artifício tapam os ouvidos, se escondem sob a mesa ou ficam cobertos em suas camas até que a celebração termine, e juntamente com ela as lembranças revividas.

Sobre a ligação da música com experiências passadas, De Nora (2000) escreve:

No nível mais básico e geral, a música é uma linguagem que pode ser, e normalmente é associada aos aspectos de experiências passadas. Foi

\footnotetext{
${ }^{48}$ Com título traduzido no Brasil como "Os Horrores da Guerra", sob a direção de Jon Alpert.
} 
parte do passado, e então se torna um emblema de uma interação mais ampla e emocionalmente complexa. Uma grande parcela desse poder afetivo da música vem de sua co-presença de outros elementos pessoas, eventos e cenas. Em alguns casos o poder semiótico da música - aqui, sua capacidade emblemática - vem de sua presença condicional; ela simplesmente estava 'lá na hora certa'. Nesses casos, os significados específicos da música e a ligação com aquela circunstância simplesmente emergem a partir das associações com o contexto em que se escuta. (2000: 66)

Concluindo a discussão, ainda sobre essa capacidade semiótica da música, Sloboda (2001) observa:

Alguns tipos de estímulos (incluindo música, cheiros e gostos) parecem se associar à memória humana através de contextos e eventos em momentos passados da vida, e possibilitam disparar o gatilho para que esses eventos sejam trazidos de volta. (2001: 545)

Para Sloboda, a música evocaria primeiramente no ouvinte os sentimentos e sensações, e posteriormente as memórias associadas àqueles sentimentos.

Conclusão: A memória auditiva é a capacidade do material sonoro de evocar no ouvinte pensamentos, sensações e sentimentos a partir da escuta. Sejam boas ou ruins, desejadas ou indesejadas, prazerosas ou traumáticas, as lembranças emergem com vivacidade, desencadeando no ouvinte uma sucessão de eventos físicos e psicológicos muito mais amplos que o ato de se escutar em si. É uma experiência certamente de cunho idiossincrático e pessoal.

\section{Função n ${ }^{\circ}$ 8: Controle do estado de espírito}

No controle do estado de espírito o ouvinte usa a música como uma ferramenta para se atingir ou manter um estado de espírito desejado e específico. Como exemplo, o ouvinte poderia se utilizar da música para relaxar até adormecer, inaugurar seu dia de forma motivadora, manter o ritmo de produtividade no trabalho, controlar a ansiedade e até superar a irritabilidade ou agressividade. Trata-se de uma expansão da função anterior, da memória auditiva. Enquanto naquela a música rememorava sentimentos e emoções do passado, no controle do estado de espírito ela trabalha, de maneira mais ampla, sobre todas as respostas emocionais possíveis de se causar, proporcionando ao ouvinte um repertório que venha sempre a se adequar ao estado de espírito almejado para aquele momento. 
Ainda que se compreenda que a música é capaz de interferir no estado de espírito de quem a ouve, e estudos aprofundem tal fenômeno (SLOBODA 1999, 2001; DeNORA 2000), ainda são nebulosas as explicações que detalham minuciosamente como isso ocorre, sendo essa relação música-estado de espírito um campo ainda em expansão.

No entanto, essa associação não é recente, uma vez que Aristóteles (2005), por exemplo, já discorria sobre os efeitos da música na alma humana. Um momento marcante dessa discussão veio à tona nos séculos XVII e XVIII, em meio ao período musical conhecido como Barroco.

Conhecida como a "Doutrina dos Afetos", ou "Teoria dos Afetos" (do alemão Affektenlehre), essa teoria estética da música era bastante aceita pelos músicos desse período. A teoria se baseava na ideia de que recursos técnicos utilizados na composição musical seriam capazes de proporcionar e despertar sentimentos e emoções específicos nos ouvintes. Ou seja, através de elementos composicionais (intervalos, harmonias, melodias etc.) específicos o compositor conseguiria produzir uma resposta emocional pré-definida e involuntária nos ouvintes. O escritor que mais se aprofundou na Doutrina dos Afetos foi Johann Mattheson, em sua obra Der Volkommene Capellmeister (1739). Nessa obra Mattheson categorizou tipos de afetos e suas conotações e associações com elementos musicais. De maneira geral o autor considera a capacidade de a música interferir nos afetos de um indivíduo como a mais importante e significativa qualidade musical (MATTHESON, 1981: 103).

De acordo com Hans Lenneberg (1958), a doutrina dos afetos “[...] não era meramente uma proposta teórica de crítica musical; era também um guia prático para os compositores” (1958: 47), de forma a resultar em uma espécie de manual de composição que disponibilizava os intervalos musicais e os respectivos sentimentos que cada um gerava nos ouvintes: a certo intervalo era atribuído o sentimento de tristeza; a outro, o de alegria, fúria, e assim por diante.

A doutrina dos afetos possuía, porém, alguns pontos bastante questionáveis. $\mathrm{O}$ primeiro era a afirmação de que realmente determinado intervalo trazia em si uma associação com um sentimento ou afeto. Um acorde menor, por exemplo, não é "triste" por si só. Se assim fosse, todas as músicas em tonalidade menor poderiam ser associadas à tristeza, afirmação essa que obviamente não merece crédito ${ }^{49}$. O segundo é o de que os sentimentos gerados pela música produziriam o mesmo efeito em todos os ouvintes, o que retiraria todo e qualquer senso de individualidade pessoal.

\footnotetext{
${ }^{49}$ Inúmeros gêneros musicais associados (pelo público geral) a um sentimento justamente oposto à tristeza possuem obras em tonalidades menores, como o samba, polka, valsa etc. Dois exemplos são as canções $O$ que é, o que é, de Gonzaguinha e Czardas, de Vittorio Monti, ambas em tonalidade menor.
} 
Apesar de uma teoria que soa um tanto restritiva (pois pregava que os resultados seriam os mesmos para todos os ouvintes), muitas das práticas contemporâneas de composição ainda parecem estabelecer vínculos diretos com esse pensamento.

A música do cinema, por exemplo, quando analisada no contexto comercial hollywoodiano, ainda trabalha extensamente com clichês harmônicos, intervalos e perfis melódicos conhecidos por despertarem determinados sentimentos nos ouvintes. Trilhas musicais de terror, por exemplo, normalmente são compostas em tonalidades menores ou atonais, enquanto o tema de amor do casal em um romance geralmente parte de uma tonalidade maior ${ }^{50}$. Tal associação do público, de que o modo menor desperta tristeza enquanto que o maior, alegria, são sabidas previamente pelo compositor, e normalmente produzem o efeito esperado. O mesmo ocorre no meio publicitário, em que, de acordo com o apelo da campanha, a tonalidade é definida, assim como os instrumentos, a harmonia e a o arranjo instrumental.

Ola Stockfelt (2004), ao discorrer sobre a escuta contextual, diz que a mesma música que acalma um ouvinte tem o potencial de irritar outro, e que a música pode ser utilizada propositalmente com uma finalidade específica, influenciando no estado de espírito do ouvinte. Assim também advogam Moebius e Annen (1994), ao afirmarem que “[...] eles (ouvintes do Walkman) podem selecionar os sons que melhor se encaixam em seu estado de espírito. Eles podem tanto intensificar o sentimento já presente quanto muda-lo" (1994: 573).

Conclusão: O controle do estado de espírito é a função através da qual o ouvinte se utiliza da música para alcançar um estado de espírito desejado ou manter o que se tem. Devido à vastidão de repertório existente e ao potencial de comunicação na relação músicaouvinte, essa intenção é quase sempre atingida. Ao menos pode-se considerar que existem meios suficientes para que esse desejo seja concretizado.

\section{Função $n^{\circ}$ 9: Controle de tempo}

Na função do controle de tempo o ouvinte considera a escuta musical como uma prática de maior valor, enquanto aproveitamento de tempo, do que outras atividades às quais

\footnotetext{
${ }^{50}$ Obviamente não se trata de uma afirmação empírica válida para todos os filmes do gênero, mas de uma constatação cotidiana tirada a partir da escuta de várias trilhas musicais dos gêneros apontados e da experiência particular do autor desse trabalho na atividade de compositor de trilhas musicais para cinema e televisão.
} 
ele poderia se engajar naquele momento. O usuário opta por ouvir música ao invés de não fazer nada, ou se dedicar a tarefas consideradas monótonas e não prazerosas.

Talvez o emprego mais direto e usual seja o do ouvinte recorrer à música a fim de ter a sensação de que "o tempo passe mais rápido". Tal situação é bastante comum em viagens longas ou momentos de espera, como filas de bancos, shows ou congestionamentos. Munido de uma mídia portátil o ouvinte conecta seus fones de ouvido e se "desconecta" da atividade à qual está engajado. Ao se concentrar na música ele se distrai do relógio, tendo a sensação de que o tempo passou mais rapidamente. Sobre essa prática Bull observa:

\begin{abstract}
A vida urbana é frequentemente experimentada como repetitiva e os usuários são frequentemente consumidos por uma rotina opressora. Eles relatam tomar o mesmo caminho para o trabalho todos os dias da semana, quarenta e oito semanas por ano. Eles também são consumidos e sugados pelos seus trabalhos, suas rotinas e suas jornadas diárias. Eles conhecem detalhadamente cada passo de suas rotinas, com sua monotonia previsível, todas as estações e o tempo necessário para se concluir a jornada diária. E se sentem oprimidos por isso. Há muito eles já deixaram de prestar atenção nos seus arredores. A utilização de um aparelho musical portátil é a única coisa capaz de fazer o tempo correr de forma suportável para esses usuários. Ao menos enquanto eles ouvem música eles não precisam pensar em sua rotina ou no escritório que espera por eles. (2000: 190)
\end{abstract}

De acordo com Bull, a escuta móvel alivia os ouvintes de suas obrigações monótonas ou exaustivas. É o caso de um viajante prestes a enfrentar horas até seu destino dentro de um ônibus ou um carro, por exemplo. Ouvir música em uma viagem, além de gerar a impressão de o tempo passar mais rápido, remete à sensação de um tempo que está sendo mais bem utilizado do que se esse indivíduo estivesse dormindo, ou simplesmente olhando a esmo pela janela. Além do mais, pode contribuir para manter desperto o motorista...

Ainda sobre o mesmo exemplo, Chambers (1994) e Berland (1998) trazem à tona um fator importante à discussão, observando a relação entre tempo e espaço para o ouvinte. Chambers afirma que "[...] o velho e geométrico modelo de cidade, tida como a organizadora de espaço, tem sido substituído pelo cronômetro e pela organização do tempo" (1994: 52). Ou seja, no caso de um viajante de carro que ruma por horas à outra cidade ou mesmo dentro de sua própria cidade, a música define esse trajeto em termos de tempo ao invés de distância. Com o acompanhamento musical, o percurso se torna uma sucessão de episódios musicais, ao invés de uma luta desgastante contra uma distância física.

Essa prática de escuta não é restrita às mídias portáteis, mas sem dúvidas elas elevam a função de controle de tempo para outro patamar. Com a possibilidade de se carregar a música consigo, o ouvinte se desprende da necessidade de estar próximo a um aparelho para 
dissociar-se da monotonia. Mesmo no caso de uma longa caminhada, ou jornada entre trens e metrôs - onde não há aparelhos disponíveis - esse usuário não fica desamparado se porta seu próprio artefato no bolso. Assim, o local e a presença ou não de uma mídia fixa de reprodução deixam de ser determinantes, permitindo ao usuário distanciar-se do cansaço da atividade exercida esteja ele onde estiver.

Deve-se salientar, entretanto, que o controle de tempo não está limitado à fuga de atividades indesejadas. Ela também abarca a opção de se escutar música frente a outras atividades indesejadas ou ao puro ócio. Seria o caso do usuário que prefere escutar música a assistir televisão, ou sair para uma caminhada. O ouvir é eleito como atividade prioritária, sem que o usuário necessariamente esteja desconfortável com o ambiente em que se encontra. Simplesmente enxerga na apreciação musical uma atividade que lhe trará maior proveito de seu tempo.

Poderíamos mencionar, enquanto exemplo hipotético, um indivíduo que, após um dia intenso de trabalho, adentra em sua casa e se dirige para um aposento de descanso. Ali liga seu aparelho de som que de imediato começa a tocar a Ária na quarta corda, de Bach. Assim esse ouvinte passa a próxima hora de seu dia, deitado em sua poltrona relaxando. Nesse caso, ao invés de relaxar em frente à televisão, ou fazer uma refeição, o indivíduo delegou à música a prioridade, controlou seu tempo através da escuta e apreciação musical.

Conclusão: No controle de tempo o ouvinte prioriza a escuta musical frente ao ócio ou outras atividades consideradas não prazerosas ou monótonas, a fim de obter a sensação de um melhor aproveitamento de seu tempo. Enquanto as mídias portáteis não são imprescindíveis para essa prática de escuta, elas ampliam as possibilidades de controle de tempo, possibilitando uma maior conveniência aos ouvintes no trato com atividades indesejadas.

\section{Função n ${ }^{\circ}$ 10: Estímulo}

Os ouvintes, no estímulo, são motivados pelo ritmo da música que escutam, e a partir desse estímulo se engajam com maior afinco na realização de atividades físicas ou atividades profissionais. O estímulo normalmente é intencional, e o ouvinte é capaz de compreender a finalidade da música que escuta.

Sloboda (1999), na obra Everyday Uses of Music Listening, conduz uma vasta pesquisa acerca da utilização da música no cotidiano dos ouvintes. A pesquisa aponta que 
$22 \%$ dos entrevistados escutam música durante as atividades de ciclismo, caminhada ou enquanto dirigem, enquanto outros $22 \%$ ouvem música durante atividades domésticas.

DeNora (2000) também observa algumas situações nas quais a música é empregada com a finalidade específica de regular o movimento do ouvinte. DeNora menciona como exemplo trabalhadores de alto-mar, que entoam cantos que são utilizados “[...] para uma variedade de tarefas específicas a bordo de um navio - como içar velas e mover objetos extremamente pesados, como âncoras" (2000: 105). A autora também lembra das tecelãs escocesas que, durante os movimentos de batidas e recolhimentos do tecido com as mãos, entoavam suas canções ${ }^{51}$, a fim de se manterem motivadas e sincronizadas pela música. (2000: 104).

O estímulo também é encontrado em manifestações públicas, como torcidas em estádios e passeatas, situações nas quais a música objetiva colocar todo o povo em sintonia, em muitos casos a fim de intimidar o oponente, seja este o time adversário ou o governo.

A mesma motivação rítmica pode facilmente ser encontrada na prática de atividades físicas. As batidas da música parecem fornecer a energia motivacional necessária para o início da atividade, ou para que o ouvinte controle a intensidade dos exercícios. Academias de ginástica e musculação tendem a fazer grande utilização dessa função com o intuito de motivar os alunos durante os treinos. Associadas a um alto volume, a música é elemento quase onipresente em tais espaços, especialmente nos ambientes direcionados para treinamentos que exigem maior desgaste e esforço físico.

Alguns autores observam essa prática, sobre a qual discorrem em suas pesquisas. Ao tratar do estímulo, Bull relata que os ouvintes “[...] descrevem se sentirem energizados. A música, com seu ritmo constante, é uma aliada" (2000: 190). Lind afirma que "[...] o Walkman o coloca no ritmo, ou o mantém, no caso de você precisar de energia para continuar (1989: 59). Merriam (1964), na obra The Anthropology of Music, diz que “[...] o fato da música incitar uma resposta física é claramente fundado em sua utilização na sociedade humana" (1964: 224). Percebe-se, dessa forma, não ser segredo a capacidade e utilização motivacional da música quando essa traz como função obter uma resposta física do ouvinte.

Enquanto geralmente no estímulo o ouvinte é plenamente consciente dos efeitos da música que escuta, ele pode também ser surpreendido, especialmente se portando uma mídia

\footnotetext{
${ }^{51}$ Também conhecidas como wauking songs, é uma prática de origem escocesa realizada pelas tecelãs durante sua jornada de trabalho. São canções rítmicas cuja finalidade era a de acompanhar o trabalho das tecelãs e coordenar suas batidas. O canto era liderado por uma pessoa, que podia tanto cantar versos já conhecidos como improvisar novos versos na hora. O restante então respondia aos versos para um breve descanso do líder. A letra possuía tanto vocábulos conhecidos quanto sílabas de caráter simplesmente rítmico e sem significado algum. Disponível em: <http://www.houseofscotland.org/waulking.html>
} 
portátil. Seria o caso do ouvinte que, sem tomar conhecimento disso, caminha no ritmo das batidas da canção que escuta, ou, durante uma atividade física, aumenta a intensidade ou o ritmo do exercício após o início de uma música mais veloz que a anterior.

Conclusão: O estímulo caracteriza-se pelo uso da música como elemento rítmico motivador, que visa estimular o usuário para que este inicie ou se mantenha engajado na atividade física ou profissional em que se encontra. Seja no bater dos pés e mãos, no caminhar com fones de ouvido, em um canto laboral ou durante a ginástica, o estímulo permite ao ouvinte tirar vantagem do exercício de sua atividade, especialmente se essa envolver alguma forma de repetição ou necessidade de sincronia mútua. A portabilidade das mídias dos séculos XX e XXI as tornam extremamente convenientes para tal função, permitindo ao usuário melhorar sua performance em praticamente todas as circunstâncias que envolvem esforço físico.

Tendo exposto estas observações cabe-nos, agora, discutir as diversas implicações da escuta em trânsito, tema do próximo capítulo. 


\section{CAPÍTULO 4}

\section{A ESCUTA EM TRÂNSITO}

\section{A Escuta em Trânsito}

A história das mídias de reprodução sonora desde o princípio foi marcada por aparelhos que trouxeram inovações não só técnicas, mas também sociais e na maneira de se escutar. A partir da década de 1980, o Walkman inaugurou uma nova forma de se escutar música, com uma tecnologia até então inédita: a capacidade do usuário construir sua própria playlist e carrega-la no aparato portátil.

Já estabelecida e assimilada pelo público geral, essa prática de escuta dominou por décadas, sendo ainda no momento presente a maior tendência da cultura do ouvir. Não a única, mas a principal.

Para os usuários do Walkman que se encantavam com a possibilidade de carregar seu repertório no bolso ou no carro, a década de 2000 havia reservado uma grande surpresa, capaz de convencê-los a abandonar o estimado Walkman e migrar para algo ainda mais surpreendente. Não se tratava de algo além da portabilidade, mas de uma portabilidade já conhecida, porém com melhorias bastante significativas.

A partir da instauração do formato MP3, diversos aparelhos ${ }^{52}$ fizeram a ponte que consagraria essa nova tecnologia como a "menina dos olhos" dos ouvintes cativados pela escuta em deslocamento. O mais popular, talvez, tenha sido o iPod.

Lançado em 2001 pela Apple sob o mote de "1000 músicas em seu bolso" 53, o iPod logo se instituiu como um dos tocadores de MP3 mais famosos do mercado, popularidade essa comprovada em números, conforme indicado pela tabela a seguir ${ }^{54}$ :

\footnotetext{
${ }^{52}$ Vários aparelhos capazes de executar arquivos digitais em MP3 foram lançados no mercado antes do iPod, como o The Audible Player (1998), MPMan (1998), Diamond Rio (1998), HanGo Personal Jukebox (1998) e Nomad Jukebox (2000), entre outros.

53 "1000 songs in your pocket". Retirado do site oficial da empresa. Disponível em $\mathrm{http}_{54} / / \mathrm{www}$. apple.com/pr/products/iPodhistory/

${ }_{54}$ Os dados da tabela foram retirados exclusivamente do site oficial da empresa: http://www.apple.com/pr/products/iPodhistory/
} 


\begin{tabular}{|c|c|c|c|c|}
\hline Apple $i$ Pod & $\begin{array}{c}\text { Ano de } \\
\text { Lança- } \\
\text { mento }\end{array}$ & $\begin{array}{c}\text { Capacidade de } \\
\text { Armazenamento }\end{array}$ & $\begin{array}{c}\text { Quantidade de } \\
\text { Músicas vendidas } \\
\text { (iTunes Store) }\end{array}$ & $\begin{array}{c}\text { Quantidade de } \\
\text { unidades } \\
\text { vendidas }\end{array}$ \\
\hline $\begin{array}{c}\text { iPod Primeira } \\
\text { Geração }\end{array}$ & 2001 & 1.000 músicas & Não informado & Não informado \\
\hline $\begin{array}{c}\text { iPod Segunda } \\
\text { Geração }\end{array}$ & 2002 & 4.000 & Não informado & 600.000 \\
\hline $\begin{array}{c}\text { iPod Terceira } \\
\text { Geração }\end{array}$ & 2003 & 7.500 & 25.000 .000 & 2.000 .000 \\
\hline $\begin{array}{c}\text { iPod / iPod Mini } \\
\text { iPod / iPod Shuffle / } \\
\text { iPod Nano }\end{array}$ & 2004 & 12.000 & 200.000 .000 & 10.000 .000 \\
\hline $\begin{array}{c}\text { iPod } \text { Classic / iPod } \\
\text { Shuffle / iPod Nano }\end{array}$ & 2006 & 16.000 & 500.000 .000 & 42.000 .000 \\
\hline $\begin{array}{c}\text { iPod Classic/ iPod } \\
\text { Shuffle / iPod Nano } \\
\text { / iPod Touch }\end{array}$ & 2007 & 40.000 & 3.000 .000 .000 & 141.000 .000 \\
\hline $\begin{array}{c}\text { iPod Touch / iPod } \\
\text { Nano }\end{array}$ & 2008 & 40.000 & 5.000 .000 .000 & 197.000 .000 \\
\hline $\begin{array}{c}\text { iPod Touch / iPod } \\
\text { Nano }\end{array}$ & 2009 & 40.000 & $\begin{array}{c}\text { Não informado } \\
\text { Downloads App Store: } \\
2.000 .000 .000\end{array}$ & 250.000 .000 \\
\hline $\begin{array}{c}\text { iPod Touch / iPod } \\
\text { Nano / iPod Shuffle }\end{array}$ & 2010 & 40.000 & $\begin{array}{c}5.000 .000 .000 \\
\text { App Store: } \\
5.000 .000 .000\end{array}$ & 275.000 .000 \\
\hline
\end{tabular}

Um fato curioso relacionado à origem do iPod é o de que, ao contrário do Walkman, ele não foi idealizado pela Apple, como relata Downey:
Tony Fadell era um trabalhador autônomo à procura de uma oportunidade de visibilidade. A ideia de Fadell era a de criar um tocador de MP3 que pudesse ser ligado a algum site como o Napster. Fadell ofereceu a combinação MP3/site de música a diversas empresas, mas a Apple foi a única que acolheu. (DOWNEY, s/d: 11)

O que torna interessante esse fato é o de que a "nova geração" das mídias portáteis, aqui representada por um de suas principais líderes de popularidade, só foi possível devido à tecnologia da internet. Ou seja, o multifacetado ciberespaço se tornou campo de frutificação de uma nova mídia. Por mais genial que fosse a ideia do iPod, ele não teria sido concebido na década de 1980, na era pré-internet, ao menos da forma que foi.

Outro fato relevante para se compreender o caminhar histórico das mídias portáteis, e que fortalece o papel do Walkman como predecessor de muitos gadjets da década de 2010 é o da influência do Walkman na criação do iPod. Conforme descreve Downey:

Em entrevista à Cult of Mac, John Sculley, ex- CEO da Apple, disse que 'o ponto de referência de Steve (Jobs) era em todo momento a 
Sony. Ele queria ser a Sony. Ele não queria ser a IBM. Ele não queria ser a Microsoft. Ele queria ser a Sony ${ }^{55}$.' (s/d, 12)

Essa afirmação por si só já parece suficiente para declarar a proporção da influência que a fabricante do Walkman possuía sobre a mais recente líder do mercado de mídias portáteis, reafirmando o papel inovador do Walkman. Segue o autor:

Na mesma entrevista, Sculley afirma ter ele e Steve recebido alguns dos primeiros Walkmans. Jobs achou aquele novo aparato de áudio bastante engenhoso. Ele também estava obcecado com a inovativa estratégia de marketing do Walkman. O conhecimento de Jobs acerca das estratégias de marketing da Sony o levaram a utilizar muitas dessas mesmas ideias na divulgação do iPod. (s/d, 12)

Como já mencionado anteriormente, essas estratégias de marketing eram quase todas associadas à mobilidade e voltadas para o público jovem, tidos como os maiores consumidores em potencial. Além do público realmente jovem, a campanha se voltava também para aqueles que não eram necessariamente jovens em idade, mas que poderiam estar tão engajados na moda quanto qualquer jovem caso fizesse uso do aparelho. O apelo, nesse caso, era vinculado a um status de participação e legitimação social, mais do que ao anseio de retornar a pertencer a um grupo cuja faixa etária já foi superada.

Comprovando tais suposições, Downey prossegue relatando uma das campanhas realizadas pela Apple para o iPod, que em muito se assemelha à da Sony na divulgação do Walkman:

\begin{abstract}
A Apple introduziu um vídeo promocional informando seus consumidores em potencial sobre o design inovador do iPod. O vídeo continha testemunhos de músicos mundialmente famosos como Moby, Steve Harwell e Seal. Esses músicos falavam sobre aspectos importantes, como a praticidade do uso, portabilidade, interface amigável e designe inovador. O comentário de Seal, talvez porque Jobs queria 'guardar o melhor para o final', perguntava aos expectadores:

'Você se lembra de quando comprou seu primeiro Walkman? Você se lembra daquele sentimento de quando você teve em mãos seu primeiro Walkman, e se sentiu como...uau! (sic) Bem, eu ainda não tive em mãos nenhum MP3 player que me fizesse suspirar uau, eu quero carregar isso comigo por onde eu for! (sic) Esse é o primeiro deles (iPod) que me fez sentir uau, ok...todos vão querer ter um desse! ${ }^{56}$ $(\mathrm{s} / \mathrm{d}, 13)$
\end{abstract}

\footnotetext{
${ }^{55}$ A entrevista na íntegra está disponível em: http://www.cultofmac.com/john-sculley-on-steve-jobs-the-fullinterview-transcript/63295

${ }^{56}$ Steve Jobs. "iPod Promotional Video". Disponível em: http://www.youtube.com/watch?v=e84SER_IkP4
} 
Outra importante estratégia de marketing empregada pela Apple, ainda derivada da Sony, era a de atrelar sua mídia a personalidades, de maneira a associar o bem a um status social. Relata Downey:

\begin{abstract}
As campanhas do iPod se tornaram parte de uma cultura pop por elas mesmas. Primeiro, em 2003, houve a campanha das 'silhuetas' para televisão, em que silhuetas pretas, usando fones de ouvido brancos, dançavam em frente a backgrounds coloridos no ritmo de artistas como 'Gorillaz' e 'The Black Eyed Peas'. A Apple continua a produzir comerciais usando a música de bandas pop e músicos, valorizando aspectos como facilidade de uso, portabilidade e cores estilosas, exatamente como Morita tinha sugerido. (s/d, 14)
\end{abstract}

Em outras palavras, a Apple passou a atrelar seu produto, na maioria das campanhas, aos artistas em voga, de maneira que seu aparelho sempre aparecia como o "produto do momento". Quando um artista deixava de ser o foco da indústria, a empresa transladava seu marketing para o novo astro do pop, de maneira que o produto era visto sempre como novo e atual.

De fato o iPod era tido, e ainda é, como um símbolo de prestígio social e coolness (assim como certos modelos de smartphones). Esse sentimento de pertencimento e engajamento social é descrito pelo professor Alf Rehn:

Os fones de ouvidos brancos já entregam. Alguns de nós, que gostamos de deixá-los pendurados balançando, optamos pelas correias dos fones do nano, deixando à mostra o iPod em nossos peitos como um crucifixo. Outros o enfiam nos bolsos, somente com os cabos sinalizando sua devoção. Alguns o carregam nas mãos, o shuffle colorido, como um distintivo de honra. (REHN, 2008: 3)

$\mathrm{Na}$ realidade Jobs queria enfatizar exatamente os mesmos aspectos que Morita havia enfatizado algumas décadas antes. E de fato a estratégia funcionou. O perfil dos usuários que na década de 1980 foram cativados pelo Walkman era o mesmo dos que na década de 2000 foram seduzidos pelo iPod. A diferença é que o iPod, em termos de vendagem, superou de longe o Walkman, “[...] vendendo mais iPods em sua curta história do que o Walkman em trinta anos de existência" (SANDOVAL, 2010) ${ }^{57}$.

Os números da tabela acima, relacionados à história e vendagem do iPod - já surpreendentes - demonstram a popularidade apenas do iPod - da marca Apple - excluindo todos os aparelhos similares de outras marcas, bem como aparelhos que englobam a função de

\footnotetext{
${ }^{57}$ Em matéria intitulada Goodbye Walkman, thanks for the iPod, Greg Sandoval questiona se o iPod poderia existir sem que o Walkman tivesse existido primeiro. Disponível em: http://news.cnet.com/8301-13579_320020573-37.html.
} 
reprodução de MP3 mas que não foram exclusivamente desenvolvidos com esse intuito específico, como o caso dos smartphones e tablets.

O que poderia justificar tamanha aceitação e consumo dessa tecnologia? Entre os principais fatores, poderíamos mencionar a portabilidade (possibilidade de carregar a música a todos os lugares), a praticidade (o ouvinte não necessita mais carregar volume, como CDs ou fitas), capacidade de armazenagem (uma vasta biblioteca de sons de milhares de músicas), som ininterrupto (não há necessidade de se trocar o lado da mídia, interrompendo a experiência da escuta), interatividade (internet, jogos e aplicativos diversos), e boa qualidade sonora (mesmo com a perda inerente ao formato MP3, a qualidade pode ser comparada à do CD ${ }^{58}$ ). Entretanto, fora os avanços técnicos, as mídias portáteis apresentam outras características que as tornam tão desejadas.

\subsection{O poder da portabilidade}

Bull (2005), ao discorrer sobre as interações do ouvinte com o ambiente através da utilização do iPod, afirma que a tecnologia do MP3 fornece aos usuários um poder de controle sem precedentes sobre suas experiências de tempo e espaço. Para o autor, esses aparelhos o fazem através do gerenciamento do estado de espírito e orientação no espaço, obtidos através do "micro-gerenciamento da música personalizada". (2005: 343).

$\mathrm{O}$ primeiro aspecto abordado é o do poder associado à capacidade de mobilidade aliado ao armazenamento da mídia:

Com a introdução da tecnologia MP3 o usuário recebeu um acesso incomparável à sua coleção musical em um caráter móvel. As gerações passadas de aparelhos, embora já provessem portabilidade, limitavam o consumidor a algumas poucas escolhas devido a seus formatos, ao passo que aparelhos como o Apple iPod permitem aos usuários o armazenamento de até 10.000 músicas. (BULL, 2005: 343344)

Para Bull, a utilização dessas tecnologias móveis seria um fator indicador da tentativa dos usuários de "habitarem" o espaço em que se encontram enquanto se movem, "[...] tanto preenchendo as lacunas 'entre' as interações de comunicação cotidianas e encontros quanto estruturando o espaço já ocupado" (ibid. 344).

\footnotetext{
${ }^{58}$ Giuliano Obici, na obra Condição de escuta: mídia e territórios sonoros (2008) discute, com maiores detalhes técnicos o formato MP3 em si e as perdas da qualidade de áudio necessárias para a existência do formato, tal como o conhecemos.
} 
De fato, quando o usuário porta sua mídia, não resta espaço vazio a ser preenchido com interações. Entre um encontro e outro, uma interação e outra, a mídia é acessada e aquela lacuna imediatamente é preenchida, envolvendo o ouvinte em sua bolha de individualidade, conforme descreve Simmel (1950).

A professora e socióloga Miriam Simun (2009) desenvolveu uma pesquisa acerca do engajamento social e comunitário dos usuários de MP3 de Londres, e a partir dessa pesquisa se coloca em sintonia com Bull quando observa que “[...] o usuário de MP3 player descreve o objeto como possuindo um poder sem precedentes contra ambiente externo, a ser usado enquanto ele trafega no mesmo" (2009: 922). Uma das entrevistadas da pesquisa nota:

O que absolutamente me encanta no iPod é que eu carrego todas as minhas músicas, e posso ouvi-las todas, como eu quiser. Eu posso customizar minha playlist... eu posso dizer 'bem, nenhuma das minhas playlists está me agradando, vou criar uma nova'... para mim o MP3 player é a melhor invenção já criada, musicalmente. (2009: 922)

Adorno (1973) acredita que qualquer interação direta entre o ouvinte e os intérpretes seja de caráter ilusório. Ou seja, o ouvinte pode ter a impressão que está a se relacionar de alguma forma com o intérprete, mas isso não passa de uma ilusão, quando na realidade nenhuma forma específica e objetiva de relação está a ocorrer. Simun parece concordar com essa proposta de Adorno, afirmando que quando o ouvinte se mune de seus fones de ouvido e "controla o ambiente", na realidade ele não está exercendo concretamente nenhuma dominação, mas simplesmente tendo a impressão de que está no controle. Assim ela observa:

Os usuários do MP3 se utilizam da música para reconfigurar o tempo e o espaço conforme caminham na comunidade urbana. Utilizando-se da música para direcionar sua cognição e emoção, esses usuários redefinem sua relação com as pessoas e lugares com que se deparam. Essas transformações incitam no ouvinte a sensação de grande controle. Eu defendo que esse controle é ao mesmo tempo delegado a si próprio de maneira ilusória. (2009: 923)

Além de Adorno, Simun reafirma o parecer de Bull (2005), no que se refere à reconfiguração da relação tempo/espaço por parte do usuário das mídias portáteis. E prossegue:

$\mathrm{Na}$ mediação cotidiana das jornadas com música, os usuários constroem ilusões de uma melhor interação de troca com o ambiente, a partir da exclusão de elementos que percebem como negativos nessa interação. No ato controlar suas experiências urbanas, ao se libertar delas, os usuários de MP3 musicalmente mediam, ao invés de mudarem de fato, aquilo que julgam problemático. (2009: 923) 
A autora conclui associando tais usuários à figura de um ator, que finge uma realidade não correspondente à verdadeira, gerando como consequência final uma “[...] reconfiguração da cidade em si, ao passo que os espaços públicos são transformados em uma coleção de prazerosos espaços privados" (idem).

Exatamente em oposição a essa constatação, e discordando de Simun e Adorno, Hosokawa (1984) advoga que o Walkman permite aos usuários descontruir e reconstruir os significados da cidade - através disso transformando-a. Para ele, a cidade não é construída somente pelas mensagens que envia, mas também pela reação dos habitantes a elas (HOSOKAWA, 1984: 172). Dessa forma, conforme os usuários de MP3 transformam os espações públicos em universos sonoros privados, eles estão a reconfigurar não somente suas relações com a cidade, mas a cidade em si.

Outra forma de poder também seria exercida através do controle pleno que o ouvinte tem a partir do momento em que pode carregar todas suas músicas com ele. O indivíduo possui um controle absoluto do material sonoro, e consequentemente do ambiente externo e de seu próprio estado de espírito, ao passo que pode (ou tem a sensação que pode) controlar todos esses aspectos a partir do manejo de seu aparelho.

Outro aspecto apontado por Bull é o da relativização da relação tempo/espaço fundamentada no preparo e no gerenciamento do material sonoro e do aparato portátil. O autor parte da constatação de que há uma profunda ligação entre o usuário e sua mídia, ponto já apresentado nesse trabalho, quando afirma que “[...] os usuários de iPod são geralmente planejadores, despendendo horas na criação de suas playlists para si mesmos em preparação para suas rotinas de idas e vindas do trabalho (2005: 344).

Infere-se dessa afirmação que existe uma espécie de rito no preparo do material sonoro, bem como no tratamento do aparato móvel. Assim como se fazia com o vinil - entre o preparo da escuta e os cuidados com o disco - percebe-se que o século XXI manteve certas tradições, que parecem peculiares à prática da escuta musical.

Uma das alegações dos defensores dos discos, quando criticando as mídias subsequentes a ele, é a de que a ausência de capas, encartes ou fichas técnicas reduziria o teor artístico da obra. No entanto, nota-se que o zelo dos usuários contemporâneos não é ausente ao seu material sonoro, mas talvez tenha sido transferido para outros fatores. É possível que um usuário assíduo de iPod na década de 2010 não valorize a arte da capa de um álbum como um amante dos discos da década de 1970. Porém, seria precipitada (senão egoísta) a afirmação de que os usuários de MP3 não possuem zelo, ou o mesmo zelo, pela sua música. 
Os software de gerenciamento de MP3, como o iTunes ${ }^{59}$, assim como os aparelhos reprodutores de MP3 (smartphones, iPods e afins) disponibilizam diversas possibilidades de organização do material sonoro armazenado, permitindo ao usuário separar suas músicas por gêneros, artistas, álbuns, títulos, entre outros. O usuário então inicia o processo de categorização de sua biblioteca musical inteira, manipulando virtualmente seus álbuns e posicionando-os nos locais virtuais apropriados, exatamente como o usuário da década de 1970 fazia com seus discos em vinil em sua estante. Ou seja, mudou a mídia, mas não o zelo. Mudaram as formas e os recursos de gerenciamento e armazenamento sonoro, mas não o apreço, tampouco a satisfação, de possuir sua coleção musical bem administrada.

O ouvinte cria, na realidade, um ciclo que se dá entre Preparo (do repertório a ser escutado) - Escuta - Prazer (gerado no ouvir o repertório selecionado), recomeçando assim uma nova preparação de repertório, seguida da escuta etc.

As mídias portáteis, para Bull, permitem ao usuário quebrar a rotina conforme reconfiguram o tempo/espaço. Para ele, “[...] essa 'desrotinização' do tempo se deve tanto ao puro prazer de se ouvir quanto ao controle do usuário sobre seus sentimentos, pensamentos e observações, conforme controla o tempo e o espaço" (2005: 344), e isso seria uma das fontes de prazer da escuta solitária.

A utilização das mídias portáteis, essa que cria um ambiente privado mesmo em situações públicas, já foi assimilada pelos ouvintes contemporâneos, que passaram a utilizar, entre outras coisas, como forma de preencher o espaço entre atividades do dia-a-dia. Bull observa:

O consumo solitário é prazeroso e ao mesmo tempo controlável. [...] A utilização doméstica (dessas mídias) ensina aos consumidores como 'preencher' o espaço e o tempo entre as atividades. Os consumidores gradativamente se acostumaram à presença da mídia mediada em nossos ambientes privados. (2005: 345$)$

O intervalo de tarefas passou a ser preenchido com a utilização das mídias portáteis. Em uma caminhada entre um compromisso e outro se manipula o celular; entre uma tarefa doméstica e outra, verifica-se a caixa de $e$-mail e, entre as atividades do trabalho, buscam-se as últimas notícias nas redes sociais. Dessa forma, o consumidor vem se viciando em ocupar seu tempo livre com as mídias. Ao contrário de nelas estar encontrando um "desligamento" do mundo on-line incorpora, por vontade própria, mais algumas tarefas diárias em sua agenda. Como bem observa Simun, “[...] para Adorno, o MP3 representaria um objeto configurado

\footnotetext{
${ }^{59}$ Software desenvolvido pela Apple para o gerenciamento, organização, reprodução e compra de arquivos de mídia digital. http://www.apple.com/br/itunes/
} 
pela indústria cultural , encorajando o vício à distração oferecida pela música através de sua escuta constante - provendo e alimentando nossa alienação" (2009: 929).

\section{Sociedade de consumo sonoro}

A aceitação e popularização das mídias portáteis desde o princípio foi tamanha assim como as similaridades entre o Walkman e o iPod - que "[...] tanto o Walkman quanto o iPod se tornaram 'marcas genéricas', produtos cujos nomes são utilizados para representar uma classe inteira de produtos" (DOWNEY, s/d: 2).

Toda essa manifestação em direção às mídias portáteis só é possível em uma sociedade na qual o som, ou a cultura musical, sejam suficientemente disseminados e alvos de consumo: Os habitantes metropolitanos parecem habituados com a onipresença da música. Seja nos rádios, televisões, cinemas, lojas, shopping centers, salas de espera, ruas ou entre fones de ouvidos, a sociedade se acostumou à música mediada. DeNora (2000) não hesita ao afirmar que a cultura de consumo contemporânea é uma cultura de consumo sonoro, na qual nosso cotidiano é cada vez mais mediado por uma multitude de sons mecanicamente reproduzidos. Bull complementa essa ideia quando escreve:

Nós acordamos com estações de rádio, caminhamos com música, dirigimos com sons e frequentemente relaxamos e adormecemos na companhia de sons mediados. A música nos segue no trabalho e está conosco nas lojas, pubs, clubes e parques temáticos. Ainda assim, apesar dessa rotina sonora em nossa sociedade de consumo, ela ainda preserva uma posição 'utópica' no desejo dos consumidores. (2005: 347).

O autor está relatando nada mais que a realidade com a qual nos deparamos diariamente. Mesmo com o consumo massivo de música, os novos gadjets crescem cada vez mais como objetos de desejo - e status - entre os consumidores, assim gerando um ciclo de retroalimentação da indústria da música e das mídias a ela associadas. Bull crê que "[...] com a criação do Walkman, e hoje o iPod, vemos uma habitação pós-Fordista do espaço urbano" (idem).

Podemos falar de uma escuta volátil ${ }^{60}$, que acompanha o fluxo das cidades, e também de um ouvinte volátil, agente protagonista dessa escuta. A escuta volátil parece bastante

\footnotetext{
${ }^{60}$ Há distinção, nesse trabalho, entre as expressões "escuta em trânsito" e "escuta volátil". A expressão "escuta em trânsito", ou "itinerante", se refere à mobilidade geográfica, em que o ouvinte se desloca geograficamente se portando de seu aparelho de reprodução sonora. A expressão "escuta volátil" é utilizada dentro de um contexto
} 
oportuna em uma sociedade também volátil em seus valores, objetos e tendências. Ao contrário de tempos passados, em que a durabilidade era tida como uma característica quase que prioritária para qualquer bem comercial ou até mesmo para relacionamentos pessoais e afetivos, hoje se encontra muito mais em voga termos como mobilidade e velocidade.

Enquanto em uma geração passada se investia alto para se conquistar um objeto material que durasse por anos, o século XXI já traz o receio em se adquirir um objeto de consumo durável que em pouco tempo se tornará obsoleto. Conforme afirma Bauman:

As pessoas que se apegam a roupas, computadores e celulares de ontem significam a catástrofe para uma economia cuja principal preocupação, e cuja condição sine qua non de sobrevivência, é o descarte rápido. (1013: 28)

Aparelhos celulares e computadores são trocados mensal ou anualmente, e não por necessidade funcional, mas por uma exigência e pressão do mercado, bem como por uma necessidade social de se apresentar perante os demais como alguém engajado nas tendências e detentor de poder, seja ele material ou moral.

\subsection{As três consequências sociais e musicais da escuta em movimento}

\subsubsection{Ubiquidade}

A ubiquidade, dentro do escopo desse trabalho, não será definida puramente como uma consequência da utilização das mídias portáteis, tampouco será debatida somente em seu vínculo com a escuta musical. Antes disso, pretende contextualizar o ambiente e o momento histórico sobre os quais as mídias portáteis e as subsequentes intervenções sociais e musicais se desenvolveram, servindo como fundação para as discussões seguintes.

\section{Mídias natas e mídias adquiridas}

Ao longo do século XX gradativamente foi se estabelecendo um certo fascínio do homem para com a máquina. Talvez orgulho, por tê-la criado de forma tão funcional e duradoura. Essa admiração não cessou após o término do movimento industrial, mas se estendeu até a década de 2010. Parece peculiar, entretanto, a forma quase afetiva com que

sociológico da escuta, se referindo à mobilidade e transitoriedade de valores e tendências às quais uma sociedade está sujeita, e da mesma forma, a escuta. 
esse vínculo tem se apresentado na sociedade do século XXI, ameaçando superar, em alguns caso, até os níveis de relação humana.

A semioticista Lúcia Santaella (1996), em trabalho intitulado O homem e as máquinas $^{61}$, reflete acerca do desenvolvimento das máquinas a partir do final do século XIX e, principalmente, da relação cultivada pelo homem para com a mesma. Partindo das máquinas mais primitivas, baseadas na repetição e força, a autora perpassa o século $\mathrm{XX}$ finalizando sua reflexão nas máquinas de caráter oposto às primeiras, ou seja, extremamente frágeis porém inteligentes e multifuncionais. Os mais significantes representantes desse novo grupo seriam os computadores e smartphones. O próprio nome smartphone já carrega em si uma característica do aparelho: a inteligência.

Números recentes apontam para uma crescente busca dos consumidores por smartphones, indicando que a cada ano mais pessoas se rendem a esses aparelhos. As vendas de smartphones aumentaram 42\% em 2013 em relação ao ano de 2012, totalizando 968 milhões de unidades vendidas mundialmente ${ }^{62}$.

Podemos questionar os objetivos dessa busca desenfreada pelo novo, seja por parte de quem produz a tecnologia como por parte de quem a consome. Seria a finalidade desses avanços apenas sustentar um mercado imensamente lucrativo ou realmente atender a necessidades de uma sociedade? Ou ambos? Um dos pilares do sistema capitalista é a criação de necessidades sobre as mercadorias, de forma que elas sejam continuamente desejadas e consumidas, promovendo o giro de capital, permitindo que o sistema assim se perpetue.

Assim, respondendo às perguntas acima, parece que a realidade vem permeada pelos dois fatores: a perpetuação do lucro e a necessidade ou demanda social. Uma das maiores empresas de computadores e gadjets do mundo, a Apple, registrou no quarto trimestre de 2012 um lucro líquido de U\$ 8,2 bilhões ${ }^{63}$. A mesma informa ainda que vendeu, no mesmo período, 26,9 milhões de iPhones, 14 milhões de iPads, 4,9 milhões de Macs e 5,3 milhões de iPods $^{64}$. Este balanço trimestral mostra a dimensão do mercado movimentado pelos eletrônicos. Obviamente, a partir desses dados, torna-se mister para uma empresa de tal porte

\footnotetext{
${ }^{61}$ Primeiramente, Santaella (1996) apresenta as máquinas musculares, aquelas que substituem a força muscular (prensa industrial, serra elétrica etc.). Depois, os aparelhos sensórios, que seriam uma espécie de extensão dos sentidos humanos (como o microscópio e o estetoscópio), significando uma extensão dos sentidos da visão e da audição, respectivamente. E por último, as máquinas de maior grau de inteligência artificial, ou máquinas cerebrais que substituem as operações cerebrais.

${ }^{62}$ Pesquisa publicada em 13 fev. 2014 pelo grupo Gartner (um dos líderes mundiais de pesquisas relacionadas à tecnologia). Disponível em: http://www.gartner.com/newsroom/id/2665715

${ }^{63}$ Site oficial da empresa no Brasil: http://www.apple.com/br/pr/library/2012/10/25Apple-Reports-FourthQuarter-Results.html [Consulta em 28 de junho de 2013]

${ }^{64}$ idem
} 
manter e alavancar seu mercado. Para isso, as novidades não são de cunho facultativo, mas obrigatórias, sejam elas úteis ou não para os usuários.

A indústria da publicidade trabalha simultaneamente, criando necessidades $\mathrm{e}$ aumentando a demanda desses aparelhos, a fim de que esse ciclo não tenha fim. Não se pode negar, no entanto, que em meio a esta roda-viva de inovações muitos recursos presentes nos gadjets realmente facilitam e aumentam o bem-estar dos usuários, como recursos de localização via satélite, mapas, aplicativos relacionados à saúde, alimentação e até mesmo meios de se produzir e escutar música.

O professor e pesquisador Norval Baitello Jr., diante da aparente supervalorização do virtual (mediado pelas máquinas) e esquecimento, ou desprezo, do valor do corpo humano este que é o primeiro e talvez mais fundamental meio de comunicação - relembra a tese desenvolvida desde 1972, pelo pesquisador Harry Pross: o corpo como sendo a primeira mídia do homem, ou seja, como mídia primária (1999: 2).

Qualquer interação entre um indivíduo e outros indivíduos seria impensável sem o corpo e suas mais diversas linguagens, como os sons, os sabores, os odores, os movimentos e as imagens. Aqui não há mídia que ultrapasse a dimensão física do corpo vivo. O homem é a mídia, e nesse papel se torna apto a se comunicar de múltiplas formas, como gestos faciais, um flerte ou uma mímica. Qualquer circunstância em que o corpo seja utilizado, ele está comunicando e funcionando como uma mídia. Em um protesto de rua, o descontentamento está, antes mesmo dos escritos das faixas, demonstrado nos corpos de quem protesta, assim como em uma ocasião diplomática o próprio comportamento corporal dita como se deve cumprimentar, onde se deve sentar etc., sugerindo que muito antes da tecnologia eletroeletrônica se tornar acessível, em qualquer período da história, uma mídia mais primordial e inata sempre esteve disponível.

É notável uma tendência, nos dias de hoje, em se confundir valores e atribuir demasiada importância ao que é secundário, minimizando o valor do que é fundamental. $\mathrm{O}$ corpo é a mídia primária e essencial, e a partir dessa mídia é que as demais aparecem e se desenvolvem. Em tempos em que o virtual se mostra mais em voga que o real, torna-se muito válida a retrospectiva de valores, especialmente quando essa nos faz retornar às nossas raízes.

Enxergar o corpo como mídia primária, entretanto, não exclui nem cria conflitos com a ideia de que outras mídias venham a se desenvolver, inclusive para somarem-se a esta. Presente em qualquer movimento corporal (e até na ausência dele) se encontra um sentido, uma mensagem a ser lida e compreendida por um corpo vivo diante de outro corpo. Este é o princípio da mídia primária. Todavia, esta apresenta uma limitação: tudo o que estiver além 
da presença física e visual de dois corpos não será compreendido, ou seja: mensagens que dependam do "além do que um corpo possa fazer" estão em xeque.

A partir dessa necessidade de se criar "aparatos que amplifiquem o raio de alcance de sua mídia primária” (BAITELLO JR., 1999: 3) é que o homem desenvolveu as mídias secundárias.

Pensemos primeiramente em acessórios, como uma máscara, que acentua traços faciais, adereços, pinturas, roupas e afins, e posteriormente em ferramentas e aparatos que prolongam, e até mesmo substituem o próprio corpo. Aqui poderíamos mencionar como exemplo a escrita, com todas suas ramificações (livros, jornais, imprensa, cartas). Nota-se que essa mídia possui um poder de alcance bastante superior à primária, não se limitando ao corpo e a seu alcance, ou como o próprio autor descreve:

\begin{abstract}
A 'mídia secundária' requer um transportador extra-corpóreo para a mensagem, vale dizer, precisa de um aparato que aumente o raio de ação temporal ou espacial do corpo que diz algo, que transmite uma mensagem ou que deixa suas marcas para que outro corpo, em outro espaço ou em outro tempo, receba os sinais. (1999: 3)
\end{abstract}

Ainda a mídia secundária encontrou sua limitação, e para auxiliá-la desenvolveu-se a mídia terciária. Esta, ao contrário das demais, requer mais do que apenas um aparato para quem emite as mensagens, mas também um aparato receptor para que as recebe. É o caso do telefone, rádio, televisão, e-mail e disco, para citar alguns. Se as duas pessoas (emissor e receptor) não possuírem os respectivos aparelhos, a mensagem não será concluída.

\title{
Multiatarefados
}

Assim afirma o jornalista Steve Thomas, sobre uma possível inversão na forma de utilização dos gadjets:

\footnotetext{
O que era esperado da tecnologia era a eliminação das tarefas mundanas da vida e o aumento de nosso tempo livre. Porém hoje parece que nossas vidas estão mais e mais complexas, sempre em movimento e preenchidas com mais tecnologia e aparelhos que demandam nosso tempo, ao invés de nos dar a liberdade. Nós estamos envolvidos em uma sociedade conectada sempre pronta, sempre em movimento. (THOMAS, 2013)
}

As palavras do jornalista parecem refletir com clareza nosso ambiente diário. Se olharmos para o lado é quase certa a chance de alguém estar munido de um smartphone, tablet, laptop ou qualquer outra mídia portátil. Isso em si não é um problema. O problema se 
dá de acordo com o nível de utilização do aparelho, a frequência com que o usuário o utiliza e a dependência da mídia.

A praticidade em resolver tarefas antes demoradas, como enviar cartas - hoje substituída pelo e-mail - fez com que as pessoas aumentassem a quantidade de tarefas diárias a serem cumpridas, e a sociedade, as famílias e o mercado de trabalho se adequaram a esse ritmo. Ao invés de substituirmos as tarefas, antes trabalhosas pelas suas versões de maior praticidade, com vistas à preservação de um tempo livre, passamos a "preencher" esse tempo que "sobrou" com novas atividades, de maneira a aumentar a lista de afazeres diários. E o tempo continuou escasso...

Como solução, passamos a gerenciar várias tarefas simultaneamente ${ }^{65}$, tornando-nos indivíduos polivalentes (multitaskers).

No entanto, isso não significa afirmar que somos mais produtivos. Ao contrário, Thomas (2013) aponta que "[...] indivíduos polivalentes sentem como se estivessem produzindo mais, quando na verdade estão diminuindo sua produtividade". O autor apresenta estudos revelando que apenas $2 \%$ dos indivíduos realizam múltiplas atividades simultaneamente com eficácia, enquanto $98 \%$ são mais prejudicados que beneficiados com essa prática (2013).

$\mathrm{O}$ advento dos smartphones contribuiu significantemente para essa polivalência, pois possibilitou que seus usuários passassem a usufruir mais de uma mídia simultaneamente, por necessidade ou impaciência. Thomas revela também um levantamento mostrando que mesmo quando as pessoas estão relaxando, elas continuam conectadas às mídias. Nesse caso, a pesquisa revelou que, enquanto um grupo de indivíduos assistia a televisão, 42\% simultaneamente navegavam pela internet, $29 \%$ falavam ao telefone e $26 \%$ trocavam mensagens pelo celular. Quando referindo-se especificamente aos smartphones - nas atividades de checar o e-mail e navegar na internet - $67 \%$ o fazem durante encontros românticos, $45 \%$ costumam fazê-lo dentro do cinema, e 33\% na igreja, durante os ritos. (THOMAS, 2013).

Nota-se um exagerado apego às mídias, ao ponto de que ao invés de se tornarem eficazmente polivalentes, tais indivíduos tem se tornado multiatarefados. Nesses casos, o sujeito torna-se incapaz de empreender de maneira satisfatória qualquer uma das várias tarefas

\footnotetext{
${ }^{65}$ Não significa que resolvamos múltiplas tarefas literalmente ao mesmo tempo. Ainda que por vezes assim ocorra, normalmente são tarefas executadas com intervalo tão reduzido entre elas que podemos considera-las simultâneas.
} 
que realiza. E, na sensação de estar resolvendo múltiplas situações em pouco tempo, acaba por não resolver efetivamente nenhuma delas.

Isso parece fugir do ideal primeiro dos avanços tecnológicos. Uma tecnologia, quando desenvolvida, visa facilitar a execução de tarefas previamente complicadas, ou ampliar a margem de atuação de um aparato limitado. Deveria, por princípio, poupar tempo aos usuários. O que se percebe, entretanto, é que a má administração por parte dos usuários pode estar distorcendo as finalidades mais centrais que justificariam a existência de tais mídias. E ao invés de se tornarem mais livres, esses usuários se tornam reféns dos aparatos e da vida cotidiana mediada.

A vida digital criou um novo nicho de consumidores mais conectados e móveis, e esses consumidores possuem menos tempo a perder. A tecnologia deveria nos libertar, mas ao contrário, parece ter nos escravizado. (THOMAS, 2013).

\section{Um convite à invasão das mídias portáteis}

Mary Meeker, responsável pela equipe de pesquisas em tecnologia global da Morgan Stanley afirma que duas tendências afetarão os consumidores, a indústria de infraestrutura e o potencial comercial da internet na próxima década (2010 - 2020): a mobilidade e as relações sociais virtuais ${ }^{66}$ (INGRAM, 2010). O estudo da analista aponta inclusive para mudanças ainda por vir:

O mundo atualmente se encontra em meio a seu quinto grande ciclo tecnológico do último meio século. Os quatro anteriores foram: a era dos mainframes ${ }^{67}$ nas décadas de 1950 e posteriormente em 1960, a era do mini-computer ${ }^{68}$ na década de 1970 e a era do computador desktop na década de 1980. O ciclo atual é a era da internet móvel. (INGRAM, 2010)

Meeker segue com a previsão do que pode vir a acontecer dentro dos próximos cinco anos:

Mais usuários se conectarão à internet através de suas mídias portáteis do que através de seus computadores desktop. [...] O crescimento exponencial da utilização da internet móvel será um enorme benefício aos consumidores, e algumas companhias provavelmente terão lucros exorbitantes (potencialmente enormes), enquanto outros sequer saberão o que se passa ao redor. (INGRAM, 2010)

\footnotetext{
${ }^{66}$ Social networking

${ }^{67}$ Um mainframe é um computador de grande porte capaz de realizar processamentos de dados complexos. Normalmente são utilizados como sistemas centrais em grandes organizações (empresas, instituições etc.).

${ }^{68}$ Mini-computer, ou mini, é uma classe de computador intermediária no espectro dessas máquinas. Situa-se entre os grandes mainframes e os pequenos microcomputadores de uso pessoal e doméstico.
} 
Meeker conclui afirmando que a utilização de internet móvel tem ocorrido de maneira substancialmente mais rápida do que a utilização da internet nos computadores fixos, ou desktop.

A mesma previsão é feita pelas pesquisadoras Janna Anderson e Lee Rainie (2009), quando relatando algumas práticas de vida da sociedade do ano de 2020:

O telefone celular é a ferramenta de conexão primária para a maioria das pessoas no mundo. Em 2020, enquanto o ULPC (Um Laptop Por Criança) e outras iniciativas para trazer a rede de comunicação digital a todos alcançou sucesso em muitos níveis, o telefone celular - agora quase tão poderoso quanto um computador - é o meio primário de conexão à internet, e o único para a maioria dos cidadãos ao redor do globo, fornecendo a informação de maneira portátil, bem conectada e a um custo relativamente baixo. (ANDERSON; RAINIE, 2009)

Essa dominação da tecnologia portátil em muito se deve à crescente procura pelos gadjets dessa categoria. Um número superior de aparelhos adquiridos significa um aumento na utilização dos recursos disponibilizados pelos mesmos, sendo o principal desses o acesso à internet. Uma pesquisa realizada pelo grupo ComScore revelou que, apenas no terceiro trimestre de 2013, os Estados Unidos atingiram a marca de 123 milhões de smartphones vendidos (THOMAS, 2013). Somente no Brasil, no ano de 2013, foi registrado um aumento de $142 \%$ e $122 \%$ na venda de tablets e smartphones, respectivamente, em relação ao ano anterior (CARNEIRO et al, 2014).

Nota-se, a partir das pesquisas supracitadas, que se por hora fala-se com frequência em portabilidade e mobilidade, muito mais será falado a partir de agora. As mídias portáteis, porém, não invadiram nosso meio, mas foram convidadas a invadir. A elas foi outorgada a liberdade de exercerem seu fascínio sobre nós e modificar nosso modo de vida. E de fato temos sido seduzidos, incorporando em nosso estilo de vida hábitos não existentes na era préinternet.

\section{Porta de acesso ao universo virtual}

O fascínio dos smartphones por vezes se apresenta em um nível alarmante, revelando que em muitos casos a interação supera a esperada relação usuário-objeto, tornando-se algo semelhante a indivíduo-companhia. 
Em recente pesquisa ${ }^{69}$, realizada pela empresa Mobile Insurance (uma das maiores do setor de seguros para celulares da Inglaterra), os dados revelaram uma alarmante proporção dos vínculos estabelecidos entre os jovens ingleses e seus aparelhos celulares. Foram ouvidas mais de 2500 pessoas entre 18 e 30 anos, todas envolvidas em relacionamentos afetivos estáveis e portadores de celulares.

Quando questionados sobre o vínculo com o aparelho, 65\% revelaram que não conseguiriam viver sem o celular, e apenas $2 \%$ revelaram que poderiam facilmente viver sem seu smartphone. Porém, os dados mais estarrecedores da pesquisa surgem na sequência: foi questionado do que estes jovens britânicos abririam mão durante uma semana, para não ficarem sem seus aparelhos celulares. Do total entrevistado, $94 \%$ abriria mão do sexo, $45 \%$ passaria sem uma das refeições básicas do dia, 71\% deixaria seus carros na garagem, e 9\% admitiu que preferia ficar sem seus próprios filhos à abrir mão do aparato.

Ou seja, estatisticamente, determinados grupos sociais já tem substituído relacionamentos humanos e familiares, bem como atividades básicas de sobrevivência, como se alimentar, pela convivência com as máquinas e com o ambiente virtual.

Faz-se necessário, então, tentar compreender o porquê de laços tão estreitos entre entidades de natureza tão distintas. Este vínculo aparentemente está enraizado na forma com que estes gadjets são utilizados.

Por serem os principais meios através dos quais as informações são compartilhadas no universo virtual, eles se tornam fundamentais para que cada indivíduo encontre seu lugar nesse espaço. Esses pequenos aparelhos funcionam como um passaporte de entrada para o ambiente virtual, e a partir deles se tem acesso às redes sociais e às informações diárias da web. E o foco é quase sempre adentrar o ambiente virtual, especialmente as redes sociais. Estes "companheiros de convívio" são parte essencial na constituição da "personalização" virtual, ao passo que sem eles não seria possível que alguém ali estivesse e se comunicasse com seu círculo social. Só se existe virtualmente quando se está conectado. O status de online representa que há vida no meio virtual, alguém está vivendo do outro lado da tela, assim como o status de offline claramente demonstra que não há ninguém ali, não há vida naquele momento por parte do outro, significando que ele está "morto" para o meio virtual. E essa interação é intensa e contínua. Os aparelhos celulares normalmente são os primeiros a receberem as novidades, sejam boas ou más, e através dos mesmos é que instantaneamente se comunica ao mundo exterior, em questão de segundos, os acontecimentos cotidianos. Sem

\footnotetext{
${ }^{69}$ Folha de São Paulo 25 mai. 2013. Disponível em: http://f5.folha.uol.com.br/humanos/2013/05/1281834-94dos-jovens-britanicos-preferem-ficar-sem-sexo-do-que-sem-celular.shtml..
} 
eles o indivíduo sente-se desamparado e solitário, podendo alcançar extremos, como a perda, ou a incapacidade de se desenvolver de maneira sadia as faculdades naturais de interação social.

\section{Ciberespaço e cibercultura}

Em meio à tamanha influência que a internet tem exercido em nossa sociedade, devemos buscar uma melhor compreensão no que refere à cultura que ela vem incorporando e disseminando em nossas casas e em nossas relações interpessoais.

O filósofo francês Pierre Lévy, referindo-se a essa nova cultura instaurada na transição do século XX para o XXI, utiliza os termos ciberespaço e cibercultura. O próprio autor assim define esses conceitos:

O ciberespaço é o novo meio de comunicação que surge da interconexão mundial dos computadores. $O$ termo especifica não apenas a infraestrutura material da comunicação digital, mas também o universo oceânico de informações que ela abriga, assim como os seres humanos que navegam e alimentam esse universo. Quanto ao neologismo 'cibercultura', especifica aqui o conjunto de técnicas (materiais e intelectuais), de práticas, de atitudes, de modos de pensamento e de valores que se desenvolvem juntamente com o crescimento do ciberespaço. (2010: 17)

Para Lévy, o ambiente digital, mais especificamente o ciberespaço, está em constante mutação e, sendo assim, desprovido de qualquer essência estável. Paradoxalmente, é justamente essa velocidade de transformação uma constante tanto do ciberespaço quanto da cibercultura. Esse dispositivo de comunicação interativa e comunitário (ciberespaço) justifica tal volume de transformações quando é entendido como um instrumento da inteligência coletiva, e quando faz desta sua força propulsora de produção virtual. Como exemplo, poderíamos citar as redes de ensino à distância, cuja característica principal é a aprendizagem coletiva.

Da mesma forma, grandes empresas se utilizam de dispositivos informatizados de auxílio à colaboração de trabalhos, em que estudantes e pesquisadores do mundo todo trocam experiências, ideias, artigos, materiais de pesquisa, imagens e outros arquivos de acordo com interesses específicos. Dessa forma, a inteligência coletiva age em prol de interesses específicos e, de certa forma, acaba sendo útil a todos os envolvidos na rede comunicativa, mesmo os remotos participantes.

Ainda como exemplo, poderíamos mencionar os diversos fóruns virtuais de pesquisa e debate. É de praxe que grandes companhias de software possuam um fórum específico para 
debates e suporte técnico. A qualquer hora do dia ou da noite, o usuário que enfrenta algum tipo de problema tem a oportunidade de acessar tais websites e ali procurar por respostas. Além de especialistas contratados pela própria empresa, tais respostas podem ser fornecidas por outros usuários, nem sempre profissionais da área, mas que podem já ter enfrentado o mesmo problema e que acharam a solução. Por vezes o especialista sequer é requisitado, sendo as soluções fornecidas pelos próprios usuários do fórum.

Uma vez que os fóruns de debate não estão necessariamente ligados a uma empresa específica, pode-se facilmente encontrar na internet fóruns relacionados a instrumentos musicais, tecnologia, artesanato, viagem, e assim por diante. Tais ambientes são amplamente utilizados para discussões sobre os mais variados temas, como informática ${ }^{70}$, viagens ${ }^{71} \mathrm{e}$ outros, funcionando como uma extraordinária fonte de troca de experiências.

A cibercultura tem tomado proporções tão distintas que o próprio perfil cognitivo dos usuários da web tem passado a ser objeto de estudo de alguns pesquisadores da área de Comunicação. Santaella, em seu livro Navegar no ciberespaço (2011), levanta a hipótese de que a navegação interativa no ciberespaço envolve transformações perceptivo-cognitivas nos usuários, ancorando sua análise na possibilidade de uma inédita forma de aprendizado e processamento das mensagens no século XXI, em um ambiente de informações contínuas e completamente mediadas.

O ciberespaço, porém, não é o paraíso intelectual que aparenta ser. Apesar de inúmeras vantagens, como as citadas acima, ele também apresenta muitos problemas e riscos a serem evitados. Conforme afirma Lévy (2010), o crescimento do ciberespaço não reflete necessariamente um crescimento da inteligência coletiva, mas apenas proporciona a esta um ambiente propício para desenvolver-se, ambiente este que tem apresentado alguns novos problemas, elencados pelo autor da seguinte forma:

\footnotetext{
${ }^{70}$ Como exemplo, pode-se mencionar um dos mais populares fóruns de informática, o Clube do Hardware ${ }^{70}$. Este fórum abrange diversos tópicos relacionados à informática, e possui inúmeras salas de discussão divididas por tópicos, como Recomendações de Produtos, Armazenamento, Placas-Mãe e Chipsets, Placas de Áudio, Placas de Vídeo, Processadores, Memórias, Periféricos, Jogos, Segurança da Informação, Edição de Vídeo e Edição de Som, apenas para citar alguns

${ }^{71}$ Ao visitar um fórum relacionado a viagens, o interessado pode perguntar: "Pretendo ir à Austrália mês que vem. Vale à pena? Alguma sugestão de roteiro?". Muito possivelmente este viajante receberá inúmeras respostas para seu post, normalmente de outros viajantes que já visitaram a Austrália e têm dicas a passar. As respostas incluem moradores locais que fornecem orientações sobre a melhor época do ano para se visitar a região, que roupas levar, que parques visitar, passeios, armadilhas para turistas, e mais uma lista sem fim de recomendações. Um dos mais conhecidos fóruns de viagens é o site Mochileiros. Este website, cujo slogan é: "Feito por viajantes. Para viajantes", possui um fórum bastante movimentado, e categorias como Destinos, Roteiros de Viagem, Relatos de Viagem, Equipamentos de Camping e Aventura, e até mesmo a categoria Companhia para Viajar. Neste último tópico, o viajante solitário anuncia seu itinerário e busca por companhia. Caso alguém se interesse, ou esteja planejando viajar para o mesmo lugar também sem companhia, os dois internautas podem combinar de viajarem juntos.
} 
Isolamento e sobrecarga cognitiva - estresse pela comunicação e pelo trabalho diante da tela; Dependência - vício na navegação ou em jogos em mundos virtuais; Dominação - reforço dos centros de decisão e de controle, domínio quase monopolista de algumas potências econômicas sobre funções importantes da rede etc.; Exploração - em alguns casos de teletrabalho vigiado ou de deslocalização de atividades no terceiro mundo; e Bobagem coletivarumores, conformismo em rede ou em comunidades virtuais, acúmulo de dados sem qualquer informação, 'televisão interativa'. (2010, p. $30)$.

O ciberespaço também tende a ser excludente, pois aquele que, por não pertencer ao mundo virtual, não acompanha de perto as rápidas mudanças da cibercultura, e delas não se apropria, tende a ficar para trás. Vale ressaltar, no entanto, que devido a sua pluralidade, seria praticamente impossível alguém pertencer e compreender na totalidade o ciberespaço. Da mesma forma, este acaba por ser bastante positivo para aquele que consegue mergulhar nesse turbilhão de águas mantendo o controle de seu destino.

Como exemplo dos benefícios proporcionados por esse ambiente - e também como exemplo de uma adequação de costumes reconfigurada pela internet - analisemos a prática do consumo de produtos cotidianos.

Uma pesquisa realizada em janeiro de 2013 revelou que muitos consumidores, antes de rumarem às compras de final de ano, recorriam a seus smartphones e tablets a fim de otimizar seus investimentos ${ }^{72}$. Entre as principais atividades estavam a pesquisa do produto anterior à compra, a compra online diretamente do fornecedor, a consulta ao feedback do produto antes de visitar a loja, a busca de cupons de oferta online antes da compra, e a compra através de um aplicativo baixado, entre outras. (THOMAS, 2013).

Se anteriormente esse mesmo consumidor gastasse horas caminhando entre lojas diversas, perdendo-se em meio às anotações comparativas de preços e gastando com seu transporte, agora ele o faz sem sair de sua casa, sem custo algum e com maior controle do produto adquirido. Sua experiência de compra foi reconfigurada pela internet.

Fenômeno semelhante aconteceu na indústria musical. A possibilidade de se adquirir músicas online acarretou inúmeras consequências - boas e más - tanto para o artista, quanto para as produtoras, distribuidoras e consumidores em geral. O ouvinte precisou se adaptar, aprendendo a lidar com as possibilidades de portar a música consigo e desenvolvendo um

\footnotetext{
${ }^{72}$ Alguns aplicativos, como o Barcode Scanner, auxiliam o consumidor na pesquisa de preços e na busca de informações sobre o produto desejado. Esse aplicativo permite que o consumidor tire uma foto do código de barras de qualquer produto, e em tempo real apresenta informações sobre o mesmo. Alguns aplicativos do gênero contam com a opção de redirecionar o usuário a sites que vendem o mesmo produto, permitindo sua aquisição online no estabelecimento escolhido.
} 
novo hábito de escuta musical que caminha em sintonia com o fluxo das transformações da sociedade contemporânea.

O ciberespaço possui uma característica de descentralização do ambiente virtual, sendo essa um dos principais pilares de sustentação da rede, pois permite uma pluralidade de pensamento e expressão, gerada a partir da heterogeneidade de seus usuários. Assim, a internet trilha um caminho cada vez mais distante da uniformização, e a cada ano abriga mais línguas e culturas, valores estes agregados a partir da utilização dessa rede por usuários de todas as partes do mundo, e em tempo real.

O que parece não mais ser motivo de dúvida é a adequação da forma de se pensar e comportar ao estilo de vida multifuncional do século XXI. As mídias que utilizamos revelam muito sobre nós mesmos, nossas prioridades, interesses e gostos. As tendências sociais que somos capazes de identificar para um futuro próximo estão sendo germinadas a partir de indivíduos envoltos por completo em uma mentalidade ajustada à mobilidade e conectividade. A ubiquidade da internet e de suas porta-vozes - as mídias - parecem habitar sobre nossas cabeças onde quer que estejamos, como nuvens que nos acompanham dia e noite.

\section{Nas nuvens}

Uma das principais características da internet é a desterritorialização, ou seja, a ausência de uma posição geográfica fixa. “Onde está a internet?”, podemos perguntar. Ela não possui um único lugar geográfico definido. Onde houver um computador conectado, independente das coordenadas geográficas, ali estará a internet. Talvez devido a essa desterritorialização é que um conceito tem ganhado cada vez mais espaço no meio tecnológico da informática: o de nuvem.

Uma nuvem não possui um local fixo no céu, mas vaga conforme as correntes de vento a impulsiona. Assim, a mesma nuvem que hoje paira sobre um edifício comercial no centro da cidade, daqui a algumas horas poderá estar sobre um lago no lado oeste, depois sobre o parque na região sul, e posteriormente sobre outra cidade, num itinerário randômico e irrepetível.

Além de sua característica aparentemente onipresente, a nuvem se destaca pela sua volatilidade, ou seja, a cada instante tomando uma forma diferente. A organização dos gases e moléculas que a formam se rearranjam constantemente de maneira que ela permanece em constante estado de alteração. Alguma semelhança com o ambiente virtual pode ser 
reconhecida nessas características. Mas em que contexto especificamente o termo nuvem se associa ao ciberespaço?

Nuvem, ou cloud computing, é uma expressão coloquial moderna utilizada para descrever uma variedade de conceitos computacionais envolvendo uma grande quantidade de computadores conectados entre si, e em tempo real, pela internet. De forma mais concreta, ela permite que, através da internet, se carregue programas e outros serviços em inúmeros computadores ao mesmo tempo, enquanto esses computadores podem também estar conectados entre si.

Até poucos anos atrás, uma pequena ou média empresa necessitava possuir um cômodo específico de sua sede dedicado exclusivamente ao armazenamento e transferência de dados. Era necessário que se possuísse um centro de dados com espaço físico, energia elétrica, sistema de refrigeração, redes, servidores e capacidade de armazenamento de informações, além de um conjunto de software e uma equipe de especialistas para instalar, configurar e executar as máquinas. Esse seria um ambiente de desenvolvimento, teste, simulação e produção. Como se não fosse suficiente, no caso de algum problema com o maquinário ou problemas técnicos com um software, era necessário entrar em contato com o suporte técnico para que o impasse fosse, com sorte, resolvido. Também a atualização de sistema poderia ser uma armadilha, pois ao atualizar um software, toda uma cadeia de outros programas associados a ele poderia ser afetada, correndo-se o risco de ter que se reinstalar grande parte do sistema.

O sistema em nuvem veio justamente para substituir esse arsenal de problemas em potencial e emaranhados de cabos, além de colaborar com os custos e praticidade dos afazeres. O serviço em nuvem permite que os dados nela lançados permaneçam acessíveis de qualquer lugar do mundo, a qualquer hora, sem a necessidade da instalação de programas, serviços ou armazenamento de dados em seu computador. Através de um sistema operacional disponível na internet, o usuário pode ter acesso a arquivos (músicas, fotos etc.), informações e programas num sistema único, independente da plataforma.

Diversas companhias do ramo da informática oferecem o serviço de nuvem, desde o Google, com o Google Chrome OS até a Apple com o iCloud. Entre as opções do Google Chrome OS está o Google Drive. Uma vez dentro do Drive, é possível criar um documento de texto. O sistema permite o compartilhamento do texto com outros usuários, de forma que todos os que aceitarem o convite de compartilhamento poderão ter livre acesso a esse texto, com total liberdade de edição. Assim, é possível que cinco pessoas diferentes, uma em cada país, acessem o mesmo texto ao mesmo tempo e criem ou editem o conteúdo 
simultaneamente, com todas as alterações ocorrendo em tempo real na tela dos demais participantes. O sistema salva o texto automaticamente, dispensando-nos dessa responsabilidade.

O que chama a atenção, no entanto, é o fato de que tudo isso foi feito sem que nenhum programa tivesse sido instalado no computador, e após o texto pronto, nenhum espaço em hard drive será requisitado, pois o texto está na nuvem, ou seja, no servidor da empresa que oferece o serviço. Caso seja desejado, o usuário pode salvar uma cópia do arquivo também em seu computador pessoal. Ou seja, através de uma nuvem é possível produzir, armazenar e acessar qualquer conteúdo sem que isso incorra na instalação de software ou esteja sujeito à disponibilidade de espaço no disco rígido do computador pessoal do navegante.

\section{Da nuvem ao solo firme}

Essa nova realidade permite outras possibilidades e abre novas portas, que até então se mantinham fechadas, transformando antigos hábitos e recompondo costumes tradicionais.

Tratemos, por exemplo, dos colecionadores de LPs. Parte do rito de se colecionar longplays estava no seu armazenamento. Um verdadeiro aficionado por discos deveria possuir um espaço físico reservado especialmente para as peças de sua coleção. Estantes, prateleiras e armários poderiam ser utilizados, com os discos organizados lado a lado, ou em posição vertical, mas sempre de forma minuciosa e linear. Tradicionalmente é costume (quase imperativo), para um colecionador, manter a ordem de sua coleção, e um lugar apropriado faz parte desse costume.

Ultimamente, os meios de se colecionar passam a um novo patamar, em que não mais são necessários espaços físicos de armazenagem, mas apenas um update do áudio digitalizado em alguma nuvem. Ou seja, hoje um colecionador musical pode manter sua coleção em um ambiente virtual, com milhões de músicas organizadas em pastas e subpastas, com o mesmo grau de meticulosidade e rigidez na disposição dos mesmos, porém sem que isso ocupe sequer um metro quadrado de sua casa. Mais uma vez o palpável se torna virtual, para o deleite de uns e desprezo de outros.

\section{A simbologia da nuvem}

Aquilo que se passou a designar como nuvem não passa de uma metáfora e, como tal, deve ser desmistificada: os arquivos transmitidos para uma nuvem de armazenamento não 
vagam pelo espaço e entram como um vírus no computador de outros usuários. Os mais leigos podem pensar que um arquivo enviado por e-mail desaparece no ar e se recompõe dentro do computador do destinatário, como um pombo correio que é solto no ar e instintivamente sabe o destino para o qual ruma. Seria demasiado ingênuo transportar a mesma abstração de pensamento de uma nuvem leve e fina, quase invisível, para o campo da informática. Trata-se aqui de algo muito palpável, com rumo pré-definido e sob total controle dos prestadores de serviço.

Aquele cenário acima citado, antes encontrado em pequenas e médias empresas, com os cômodos indizivelmente repletos de cabos e energia, ainda existem, mas não mais dentro dessas pequenas empresas. As grandes companhias, fornecedoras dos serviços de nuvens, como o Google ou a Apple, possuem não apenas um cômodo, mas incalculáveis metros quadrados de servidores conectados entre si, sob um rígido controle de temperatura e segurança, a fim de que sejam capazes de armazenar as informações do todos seus usuários espalhados pelo mundo. Ou seja, quando se cria uma conta online e se produz um texto colaborativo entre amigos, esse texto necessita de um computador para ser alocado. Se não é o computador do usuário, algum outro necessariamente precisará preservar este arquivo, e estes computadores são os das empresas que disponibilizam os serviços de nuvem $^{73}$. Logo, de abstrato não há nada, e não se deve misturar os conceitos e imagens de uma nuvem do céu com uma nuvem do ciberespaço. O nome permanece o mesmo, mas a natureza e a funcionalidade são radicalmente diferentes.

Outra relação semiótica que parece se aliar e contribuir para a popularidade das nuvens é o fato de uma nuvem estar quase sempre associada a sensações positivas. A nuvem normalmente carrega uma conotação de leveza e paz, por isso sendo frequentemente associada, no mercado publicitário e no varejo, a lojas especializadas em artigos para bebês e pijamas. A nuvem remete ao sonho, pressupondo que dormir é algo relaxante e que proporciona paz interior, e daí a quantidade de estabelecimentos (lojas de colchões, artigos para recém-nascidos, móveis e roupas infantis, escolas de educação maternal e educação primária etc.) utilizarem uma nuvem como logotipo ou nomes que remetem ao mesmo contexto Alguns exemplos ${ }^{74}$ são: Sonhart ${ }^{75}$, Escola Infantil Nuvem dos Anjinhos ${ }^{76}$, Centro

\footnotetext{
${ }^{73}$ Para uma referência mais precisa acerca do espaço físico utilizado por uma empresa como o Google para seu banco de dados, alguns sites disponibilizam imagens e dados mais precisos, como encontrado no endereço http://www.news.com.au/technology/google-reveals-top-secret-data-centers/story-e6frfro0-1226498166064 (Consulta: 05 de julho de 2013)

${ }^{74}$ Todos os nomes aqui exemplificados são de estabelecimentos encontrados via internet e com marca registrada, escolhidos aleatoriamente. A presente pesquisa não possui nenhum incentivo nem interesse comercial ao citá-los, sendo a escolha das empresas de caráter única e exclusivamente exemplicativo.
} 
de Educação Infantil Nuvem de Algodão ${ }^{77}$, Centro de Educação Infantil Nuvem Branca ${ }^{78}$, Moda Infantil Nuvem de Mel ${ }^{79}$, Sonhos de Bebe ${ }^{80}$, Sonhos de Ninar ${ }^{81}$, Sonho Mágico ${ }^{82}$, Buffet Sonho Mágico ${ }^{83}$, apenas para citar alguns.

A nuvem também pode ser relacionada com a imaginação e criatividade. Basta observarmos como esses fenômenos são representados nas histórias em quadrinhos, por exemplo. Ao pensar, ter uma ideia ou para representar que os personagens estão sonhando, as palavras e imagens são apresentadas dentro de uma nuvem, que por si só informa que se trata de algo íntimo, e não de uma atitude exteriorizada.

Como se observa, o símbolo da nuvem geralmente é bem aceito e traz em si conotações e significados positivos. Não é à toa que a expressão "estar nas nuvens" é utilizada para representar o grau máximo de satisfação e gozo diante de alguma situação. Dentro ou fora do ciberespaço, a tendência é sempre encontrarmos uma nuvem leve, límpida e acolchoada, e jamais uma nuvem pesada de tempestade, pois essa acarretaria o risco de um significado contrário ao almejado pela publicidade, o que colocaria certamente em risco a rentabilidade da marca que a esse símbolo se associasse.

O conceito de nuvem tem se disseminado largamente no internet, e tende a crescer, uma vez que grandes corporações tem feito um uso cada vez mais intensivo dessa estrutura para suas mais diversificadas formas de trabalho, e também usuários comuns tem se afeiçoado de forma crescente a esse tipo de serviço para uso pessoal, através de sites como o SoundCloud ${ }^{84}$, em que o usuário cria uma conta e ali posta suas composições, possibilitando acesso remoto de qualquer lugar do mundo. Como se não fosse seguro o suficiente, agora a preservação de seu repertório não depende do estado de conservação ou vida útil do hard drive, mas está seguro nas nuvens, bem acima da poeira e não sujeito a quedas.

\footnotetext{
${ }_{76}^{75}$ Loja de pijamas e moda infantil. http://www.sonhart.com.br/ Consulta em 08 de julho de 2013

${ }^{76}$ https://www.facebook.com/pages/Escola-Infantil-Nuvem-dos-Anjinhos/478679805501485 Consulta em 08 de julho de 2013

${ }^{77} \mathrm{http} / / /$ nuvemdealgodao.com/ Consulta em 08 de julho de 2013

${ }^{78} \mathrm{http}: / /$ www.hagah.com.br/pr/curitiba/local/219413,2,centro-de-educacao-infantil-nuvem-branca.html Consulta em 08 de julho de 2013

${ }^{79} \mathrm{https} / / / \mathrm{www}$. facebook.com/pages/Moda-Infantil-Nuvem-de-Mel/325123820843876?hc_location=timeline Acesso em 08 de julho de 2013

${ }^{80}$ Loja de móveis, enxovais e decoração para bebês. http://www.lojasonhosdebebe.com.br/ Consulta em 08 de julho de 2013

${ }^{81}$ Loja de móveis, enxoval e acessórios para bebês. http://www.sonhosdeninar.com.br/ Consulta em 08 de julho de 2013

${ }_{82}^{82}$ Moda infantil. http://www.sonhomagicomodabebe.com.br/ Consulta em 08 de julho de 2013

${ }^{83}$ Organização de festas infantis. http://www.sonhomagicoeventos.com.br/index.php Consulta em 08 de julho de 2013

${ }^{84}$ https://soundcloud.com/ [Consulta em 08 de julho de 2013]. SoundCloud é uma plataforma online de publicação de áudio utilizada por profissionais de música com a finalidade principal de divulgarem e compartilharem seus trabalhos.
} 
O jornalista Will Westlake (2014) prevê que em breve trataremos não de uma nuvem apenas, mas da interligação e funcionamento mútuo de várias nuvens, uma especializada em cada setor social:

Vale a pena considerarmos não somente uma nuvem, mas várias... na realidade, quantas forem necessárias. Nuvens pessoais, nuvens privadas, nuvens locais, nuvens governamentais, nuvens escolares, nuvens sociais, nuvens rurais etc.[...] Um exemplo que pode tornar mais fácil a compreensão: carros conectados do futuro. Conforme seu carro trafega na estrada, ele estará em comunicação com os demais carros ao redor, negociando velocidades, ultrapassagens, frenagens, emissão de $\mathrm{CO} 2$ e eficiência, tudo isso em um nível de nuvem local o local sendo o perímetro ocupado pelos carros ao seu redor - mas ele também terá um link com uma nuvem de serviços meteorológicos, que enviará informações sobre as condições da estrada, bem como previsões para o gerenciamento do percurso e tempo de viagem. Seu carro também estará em diálogo com a nuvem do governo, a fim de pagar os impostos de acordo com a hora do dia, as emissões (de carbono) etc., assim como estará em sintonia com a nuvem da estrada, obtendo informações sobre as condições do trânsito à frente e as leis daquela rodovia. (WESTLAKE, 2014)

Mas as previsões de Westlake são ainda mais ambiciosas, contando também com a possibilidade de uma interação com nuvens distantes da posição geográfica do usuário, fazendo valer o princípio da desterritorialização virtual:

Isso tudo (o carro) pode estar conectado à nuvem da casa do usuário, permitindo a transmissão de mídia, como música e vídeo de sua nuvem de mídia, bem como dialogar com a nuvem de seu destinatário, mantendo-o informado sobre sua provável hora de chegada. Quanto mais você considerar as interações, mais benefícios podem ser tirados delas, e mais nuvens podem ser agregadas. Toda essa informação poderá então ser utilizada em prol do planejamento de melhorias na estrada, mudanças nos limites de velocidade e planejamentos de necessidades futuras da comunidade relacionadas a viagens. (2014).

Tamanha ousadia só é possível quando se pensa em uma quase onipresença da internet - o oxigênio, que mantém vivas todas essas tecnologias derivadas. Essa ubiquidade, no entanto, já é real, e as palavras de Westlake, que há algumas décadas poderiam soar completamente utópicas e insanas, hoje podem ser analisadas de forma crítica e sem escárnio algum, visto que a qualquer momento o vento do ciberespaço pode soprar a favor das nuvens e concretizar lá no alto o que hoje são hipóteses aqui na terra.

O objetivo final é sempre o progresso. Talvez não mais aquele quase utópico, da prosperidade coletiva, mas o progresso individual, aquele financeiro, familiar. Esse objetivo, todavia, deixou de ser opcional, como afirma Bauman: 
O progresso, em suma, passou do discurso da melhoria compartilhada da existência para o discurso da sobrevivência pessoal. Ele não é mais pensado no contexto de um desejo de velocidade, mas de um esforço desesperado para não sair fora do caminho e evitar a desqualificação e a exclusão da corrida. (2013: 27)

Para Bauman, vivemos em uma constante competição conosco mesmos e com os demais membros da sociedade na qual, a todo o momento, devemos nos mostrar atualizados e "antenados" nas novas tendências, para assim não sermos "excluídos da corrida". E na tentativa frenética de nos mantermos na pista, agimos (e erramos) impulsivamente. Talvez não seja o sistema em si problemático, mas nossa falta de adaptação para com ele, afinal, a cibercultura não possui mais que trinta anos de idade.

O autor ainda observa a exigência da sociedade contemporânea em que sejamos capazes de adquirir a aptidão para mudar de identidade (ou pelo menos sua manifestação pública) com tanta frequência quanto "trocamos de camisetas ou meias". E por um preço módico, ou nem tanto, o mercado de consumo vai ajuda-lo na aquisição dessas habilidades, em obediência à recomendação da cultura (BAUMAN, 2013). E conclui retornando ao cerne do funcionamento da cibercultura:

O tempo realmente passa, e o truque é manter o mesmo ritmo dele. Se você não quer afundar, deve continuar surfando, ou seja, continuar mudando, com tanta frequência quanto possível, o guarda-roupa, a mobília, o papel de parede, a aparência e os hábitos - em suma, você. (2013: 27)

\subsubsection{Fragmentação}

Em 1903, o sociólogo alemão Georg Simmel, em seu artigo intitulado The metropolis and mental life escreveu sobre o modo de vida dos habitantes das metrópoles, tratando especificamente do fluxo de transmissão e recepção de mensagens no meio urbano, e alguns efeitos que esse fluxo poderia estar causando nos habitantes. Em outras palavras, o trabalho analisa alguns aspectos da vida contemporânea com referência a seu significado interior na vida dos habitantes.

Para isso, Simmel primeiramente centra sua atenção nos ajustes e modificações realizadas pelas pessoas em resposta às forças externas, e posteriormente detalha como as estruturas sociais determinam certos relacionamentos.

Para Simmel o ambiente urbano possui demasiados estímulos sensoriais (especialmente quando confrontado com o ambiente rural), e isso seria motivo de incômodo 
ao cidadão. Devido à intensificação cada vez maior dos estímulos externos e internos, e constantes do fluxo desses estímulos, os indivíduos buscariam um refúgio fora deles, criando para si uma espécie de "bolha de proteção" na qual estariam livres dessa agressão, ao menos temporariamente.

Quando comparando o ambiente urbano e rural, assim diz o autor:

Em cada atravessar de uma rua, com o tempo e a multiplicidade da vida econômica, ocupacional e social, a cidade instaura um profundo contraste com as cidades pequenas e a vida rural, com referência às fundações sensoriais da vida psíquica. [...] Aqui (ambiente rural) o ritmo de vida e os estímulos sensoriais mentais fluem mais vagarosamente, mais naturalmente, e de maneira mais equilibrada. (SIMMEL, 1950: 410)

Prosseguindo com sua análise referente a esse insensível modo de vida urbano, Simmel afirma que uma metrópole é movida pelo dinheiro, e que o dinheiro possui um papel fundamental nesse estilo de vida, inclusive tornando os indivíduos mais insensíveis. Afirma ele:

As metrópoles sempre foram o refúgio da economia monetária. [...] A economia monetária e a dominação do intelecto estão intrinsicamente conectados. [...] A pessoa intelectualmente sofisticada é indiferente a toda individualidade genuína, porque relacionamentos e reações resultam dessa, que não pode ser explicada através de operações lógicas. (1950: 411).

Simmel associa a economia monetária ao sujeito intelectualizado e empírico, sugerindo que uma pessoa assim se tornaria insensível a aspectos emocionais e interiores do ser-humano, uma vez que essa dimensão é de caráter subjetivo, e não pode ser explicada com fórmulas ou pela lógica. Assim, a metrópole seria um ambiente que encoraja a insensibilidade, cujos habitantes não tem tempo nem são estimulados a lidarem com seu lado interior e com suas emoções. Pelo contrário, são constantemente estimulados a se encaixarem na exatidão dos números e ponteiros dos relógios. Simmel diz:

A mente moderna tem se tornado mais e mais matemática. [...] Somente a economia monetária tem preenchido a vida os dias de tantas pessoas com pesos, cálculos, determinações numéricas, com uma redução dos valores qualitativos em vista dos quantitativos. (1950: 411)

E conclui afirmando:

[...] se todos os relógios de Berlim subitamente perdessem o compasso de maneiras diferentes, mesmo que por apenas uma hora, toda a vida econômica e a comunicação da cidade seriam interrompidas por um longo tempo. (idem) 
O problema central estaria atrelado ao fato de que nenhuma pessoa consegue viver separada de seus sentimentos e de sua vida emocional. O habitante da metrópole estaria sendo podado dessa experiência a cada minuto que tenta sobreviver à agressividade urbana, tornando-se ao mesmo tempo insensível com as emoções do outro e infeliz por não conseguir administrar da forma ideal sua saúde psíquica e mental, afinal, "[...] em suma, a cultura da modernidade líquida não tem um 'populacho' a ser esclarecido e dignificado; tem, contudo, clientes a seduzir" (BAUMAN, 2013: 21).

Bull (2005) também se manifesta em sintonia com Simmel quando diz:

As preocupações de Simmel eram com a sobrecarga sensorial, multidões, estranhos, e o turbilhão de barulhos urbanos aos quais os cidadãos reagem. Simmel esquematizou a natureza mutante da civilização burguesa dentro da geografia urbana que gradativamente crescia tecnologicamente no início do século XX, endereçando-se à natureza dos relacionamentos e os problemas associados às pessoas continuamente em movimento na cidade. (2005: 352).

Ainda de endereçando à problemática dos fortes estímulos do meio urbano, Bull descreve como os usuários das mídias portáteis se utilizam dela como um recurso que os ajudam a suportar esse meio:

Muitos usuários raramente mencionam os espaços que eles cruzam diariamente em seu caminho para o trabalho. [...] O usuário frequentemente está mais atento a seu próprio estado de espírito e orientação, os quais são facilitados pelo som que sai de seu iPod em harmonia com o 'clima' almejado. [...] Os usuários de iPod reorientam e re-espacializam sua experiência. (2005: 352)

Com a atenção voltada para sua mídia, esses usuários se ausentam da rotina que os acomete, amenizando o peso das atividades cotidianas conforme reconfiguram seu tempo e espaço.

O professor e pesquisador em Comunicação José Eugênio Menezes (2007) propõe uma reflexão acerca da sincronização dos ritmos nas grandes cidades, delegando aos sistemas comunicativos - em especial ao rádio - o papel de articularem os tempos individuais e os tempos coletivos, de forma que, a qualquer hora do dia, as ondas de rádio geram uma teia de vínculos que viabiliza a organização da vida social nas metrópoles.

A complexidade dos estímulos urbanos citados por Simmel (1950), Bauman (2003; 2013) e Bull (2005) é aqui reafirmada por Menezes (2007), sendo que esse amplia a discussão enquanto a encaminha para a intrincada teia de comunicação e sincronia social das metrópoles. 


\section{A fragmentação midiática e musical}

Acompanhando o fluxo de movimento das metrópoles, as mídias também criaram seu próprio fluxo de desenvolvimento, afinal, elas são responsáveis por grande parte dos estímulos já mencionados por Simmel (1950).

Para que haja um fluxo corrente e veloz de informações, é necessária uma substituição constante das mensagens transmitidas. A partir desse princípio instaura-se uma cultura da mobilidade, mas não somente de caráter geográfico, mas também referente às tendências, relacionamentos e modos de consumo urbano.

A tendência, sob essa perspectiva, é uma fragmentação cada vez maior das mensagens, a fim de que essa possa logo dar espaço à que vem atrás, sem tempo de esperar. A rotatividade tem sido testemunhada diariamente em várias facetas da sociedade, desde relacionamentos até as vitrines de lojas.

A fragmentação também tem sido testemunhada nas mídias de reprodução sonora (entenda-se no material veiculado - a música em si) especialmente a partir da mediação tecnológica. Sobre esse fenômeno assim observa Iazzetta:

Os meios de gravação, ao colocarem músicas de épocas diferentes para serem reproduzidas de um mesmo modo e dentro de um mesmo ambiente, forçaram o estabelecimento de uma nova compreensão do repertório musical. (...) Trechos de árias de ópera ou motivos de sinfonias passaram a ser extraídos de seus contextos para tornarem-se pequenas peças musicais autônomas. A fragmentação tornou-se hábito. (2009: 41)

Um dos principais agentes para a viabilização e popularização desse processo foi o computador pessoal.

A partir do momento que ferramentas de edição se tornaram acessíveis e ao alcance da massa, o ouvinte deixou sua poltrona, seu lugar passivo, tornando-se também "compositor". Transforma o fragmento que mais lhe agrada da sinfonia em seu toque de celular, ignorando o restante da obra. Enquanto muitos talvez reconheçam a abertura da Sinfonia ${ }^{\circ} 40$ de Mozart por ter sido abusivamente utilizada como toque de celulares - poucos devem conhecer os compassos seguintes da obra, ou os movimentos seguintes. Alguns talvez sequer saibam que a música em questão faz parte do repertório clássico. Neste caso a fragmentação se posiciona no incômodo lugar de agente propagador e "deseducador" ao mesmo tempo.

Parte da problemática associada ao processo de fragmentação reside em algumas das consequências proporcionadas por ela no comportamento geral da sociedade. 
Acostumados com as rápidas mudanças dos estímulos sociais (campanhas de televisão, moda, showbusiness etc.) os cidadãos parecem ter, como alternativa para sobreviver nesse meio, se enquadrado no compasso dessas mudanças, igualando seu ritmo ao andamento externo. Com isso certos fatores associados ao comportamento social dos indivíduos parecem terem sido afetados, como o senso de urgência, a paciência e a tolerância. A disposição para com a espera parece ter reduzido, seja no aguardar pela carona, na fila do banco ou na aquisição de novos produtos. Os indivíduos parecem tão multifuncionais quanto às mídias que carregam no bolso. E quanto mais tarefas a serem cumpridas, menor a tolerância com demoras. O indivíduo, assim, tende a substituir sua capacidade de reflexão pelo impulso da impaciência.

E o mercado acompanha essa tendência. Como um breve exemplo, pensemos no aplicativo Shazam ${ }^{85}$. Compatível com a maior parte dos smartphones trata-se de um aplicativo capaz de identificar uma música enquanto ela está sendo tocada em um ambiente e, em tempo real, mostrar o artista, o álbum e onde a música pode ser adquirida. Basta acionar o aplicativo para que, ligado a um banco de dados de milhões de músicas ${ }^{86}$, ele reconheça a canção e devolva os dados ao usuário.

A praticidade e a rapidez são pontos altos desse aplicativo. Com ele em mãos, o usuário não precisa esperar tempo algum para descobrir todas as informações que o interessam a respeito da música. Caso a mesma música estivesse sendo tocada em uma rádio, o usuário teria que esperar até o final dela (ou por vezes do programa) na expectativa de que o locutor listasse as músicas executadas ao longo do programa, para finalmente descobrir o cantor e o nome da canção.

\section{A fragmentação pela limitação tecnológica}

A fragmentação, em muitas ocasiões, não depende do "ouvinte-compositor", mas puramente da mídia associada à escuta, como uma fita cassete e o CD. Iazzetta observa:

Essa seleção oscila entre critérios estéticos e de popularidade, mas sofre também uma grande influência do meio: a capacidade de um cilindro de gravação determinava a duração do fragmento a ser registrado. O mesmo ocorreu com outras mídias, como os discos de vinil, os CDs ou os DVDs. (2009: 41)

\footnotetext{
${ }^{85}$ http://www.shazam.com

${ }^{86}$ Dados retirados da página oficial da empresa, na Internet.
} 
Ou seja, por vezes a fragmentação é fruto de uma limitação tecnológica, não dependendo das vontades do ouvinte.

Crowl (2009) relembra que o CD foi inventado pela Sony, e que sua duração de setenta minutos deveu-se - assim se acredita - à paixão de seu fundador, Akio Morita, pela $9^{\mathrm{a}}$ Sinfonia de Beethoven na versão da Filarmônica de Berlim, sob a regência de Karajan, que totaliza setenta minutos. Assim teria se definido o limite musical do CD.

Caso se deseje gravar, por exemplo, a Sinfonia $n^{\circ} 3$ de Mahler em CD, essa obra teria que ser dividida em duas mídias, por contar com aproximadamente cem minutos de música. Se Morita fosse um apaixonado por Mahler talvez ela coubesse em apenas um CD... Mas é fato que obrigatoriamente toda mídia possui e deve ter um limite de armazenamento. Mesmo o MP3, que oferece aparelhos com capacidade para 40.000 músicas, possui esse limite, e o ouvinte sedento por suas discografias pode se frustrar ao ter que substituir, de tempos em tempos, o repertório de seu aparelho.

A propósito, essa é uma outra possibilidade criada juntamente com o Walkman: a do ouvinte reciclar sua mídia quando enjoa de seu conteúdo sonoro. No caso da fita cassete, o ouvinte poderia facilmente gravar outro conteúdo sobre o inicial, bem como comprar uma nova fita e regravar sua nova coletânea. $\mathrm{O}$ mesmo com o CD. Ainda que um tanto limitado para se aproveitar a mesma mídia para um nova sobreposição de canções (possível nos CDRW, ou regraváveis), era facilmente substituído por outro CD novo. E agora o MP3, talvez com a maior praticidade entre todos os anteriores. Com alguns cliques o usuário apaga completamente sua playlist, reconfigurando-a conforme sua vontade, e o melhor, o material sonoro não se perde, mas fica à disposição para o momento em que o ouvinte sentir saudade da música que achou que nunca mais iria querer ouvir e apagou de seu gadjet.

\section{Muzak e a escuta fragmentada}

A partir do contexto social da fragmentação, bem como da limitação tecnológica desse processo, desenvolveu-se uma escuta também fragmentada, construída a partir da compreensão de trechos descontextualizados. Campanhas publicitárias de massa estão repletas de obras fragmentadas. Trechos de canções populares são costurados como colcha de retalhos, e loops são repetidos a bel prazer, em muitos casos sem sequer o zelo da preservação de aspectos musicais, como a coerência nas cadências harmônicas.

Especialmente no mercado publicitário a música parece ser regida sob a estética medieval de música funcional, mas ao contrário daquela funcionalidade, que era voltada ao 
rito sagrado, essa está conectada à colaboração com a campanha, podendo por vezes estar em primeiro plano, como no caso do jingle, ou em segundo plano, no papel de "trilha de fundo". Sobre essa segunda perspectiva, que aqui mais nos interessa, nos deparamos de imediato com o termo Muzak.

Para muitos ele já soa familiar, porém sob o codinome de "música de elevador" (também conhecida como easy listening music, ou smooth jazz). Trata-se de uma música extremamente funcional e com fins comerciais. São músicas predominantemente instrumentais (que podem ser inéditas ou arranjos de canções conhecidas) cujos destinos são as caixas de som de shopping centers, lojas de departamentos, sistemas de esperas telefônicas, cruzeiros, aeroportos, consultórios médicos e, claro, elevadores.

A funcionalidade deste tipo de música costuma estar enraizada em uma condição: não podem ser demasiadamente percebidas. A música deve ser ouvida, mas não escutada. Trata-se de uma música ambiente, cujo propósito é o de induzir os visitantes de um determinado local a comprarem mais, ou a se sentirem à vontade e relaxados naquele ambiente. Baseia-se em uma espécie de manipulação psicológica indireta - porém com objetivos prévios traçados de forma bastante direta - funcionando como uma moção musical que, teoricamente, levará o ouvinte a ser envolvido pelos interesses em questão.

Partindo desse princípio, foi criada então em 1934, na Carolina do Sul, a Muzak Holdings $L L C{ }^{87}$, uma corporação especializada no fornecimento de "músicas de elevador", com forte apelo comercial. Esta corporação se propõe a, a partir de músicas cuidadosamente escolhidas, ajudar a aumentar o lucro de qualquer estabelecimento em qualquer parte do mundo. Para se compreender melhor a abrangência da empresa, a mesma afirma que possui aproximadamente dois milhões e seiscentas mil músicas disponíveis, e estima-se que diariamente mais de cem milhões de pessoas ouvem suas músicas ao redor do mundo. ${ }^{88}$

Percebe-se, então, o distanciamento estabelecido entre a Muzak e a escuta estrutural proposta por Adorno. Enquanto a primeira seria arruinada com o menor grau de concentração do ouvinte, a segunda depende diretamente da mesma concentração para se estabelecer. Adorno (1973), aliás, teria muito a dizer a respeito do Muzak, se mostrando radicalmente contra essa banalização da música imposta pela indústria cultural, não havendo sentido uma música ser executada com o intuito de que o ouvinte não estivesse atento a ela. Da mesma forma, Schafer (1997) a critica severamente, referindo-se a ela como Moozak, e afirmando que esta "reduz uma arte sagrada à baboseira. [...] é música para não ser ouvida" (1997: 145).

\footnotetext{
${ }^{87}$ Para mais informações, visitar o site da empresa: http://www.muzak.com/.

${ }^{88}$ Dados retirados do site oficial da empresa.
} 
Bull (2005) acredita que as mídias portáteis podem estar colocando fenômenos como o Muzak em xeque, ao passo que em tempos de individualização, continua-se a se trabalhar com a generalização:

\begin{abstract}
Esse ambiente sonoro empacotado dos supermercados, lojas de departamentos ou clubes não mais satisfazem os desejos dos usuários. Isso apesar da prevalência contemporânea do marketing de nicho de clubes ou lojas de roupas, que criam um ambiente sonoro supostamente desenhado para seus consumidores prediletos. O uso do iPod demonstra que, para muitos usuários, a particularidade de suas narrativas musicais e controle de estado de espírito não é mais preenchida mesmo pelas produções 'sob medida' de ambientes sonoros. Os usuários de iPod frequentemente se referem ao senso de poder e encantamento atingidos precisamente através da individualização de seu 'espaço representacional'. (2005: 347)
\end{abstract}

O Muzak, por mais amplo que seja, trabalha com a generalização. Ou seja, a música da loja é a mesma para todos os consumidores, assim como a das festas é a mesma para todos os participantes, e assim por diante. Como já visto, as mídias portáteis tem disseminado cada vez mais o prazer do controle sobre o ambiente e a independência do ouvinte acerca do material escutado. A playlist escolhida após horas de triagem e a parte do indivíduo refletida em tal playlist (penso que muito da personalidade dos ouvintes pode ser deduzida de suas playlists) evocam a sensação de domínio, de forma que eles se sentem em algum grau representados e satisfeitos com a particularidade de suas playlists. Assim, o Muzak torna-se genérico, não mais atingindo o ouvinte em seu âmago. Não é capaz de agradar totalmente a todos, talvez hoje nem mesmo à maioria. Antes, o ouvinte parece preferir sua própria lista de músicas à imposta e impessoal.

Talvez seja difícil mensurar, todavia, até que ponto as mídias portáteis tem de fato interferido comercialmente na indústria de "músicas ambientes", como a Muzak. Apesar de gradativamente mais e mais usuários serem vistos a cada dia com suas mídias portáteis, há ainda uma grande parcela de consumidores não adeptos a essas mídias, e que não portam seus aparelhos consigo. Para esses consumidores a Muzak (bem como as demais empresas do ramo) ainda parece funcionar e ter sua eficácia comprovada.

\title{
Álbum x Single
}

Instituído e consagrado com os LPs desde a década de 1950, o formato álbum por muitas décadas dominou a indústria musical. Trata-se de uma sequência de músicas de número variável, que possui certa coerência entre as faixas, organizada e comercializada em 
uma mesma mídia. Um álbum contém também uma arte - fator agregador de muito valor - na capa e na contracapa, além de informações reunidas em uma ficha técnica relacionando os principais envolvidos no projeto, como os músicos principais, artistas convidados, fotógrafo, produtor, distribuidora, entre outros. Além disso, também traz um encarte normalmente contendo as letras das canções e outras informações, como o nome do compositor de cada faixa, e em muitos casos uma arte própria do encarte, diferente das da capa e contracapa.

O formato álbum ganhou tamanha força que mesmo após a digitalização da música esse tipo de produção continuou a ser comercializado, como ocorreu na transição entre o LP e o CD. O jornalista e pesquisador Leonardo De Marchi (2005) utiliza o termo estética do álbum para se referir à possibilidade de se gravar várias faixas com alguma ligação entre si em uma mesma mídia.

No entanto, o advento do MP3 e a cultura digital permitiram que a fragmentação alcançasse também esse formato, de forma que a produção e comercialização dos álbuns tem sido colocadas em xeque pela crescente busca dos consumidores por faixas individuais. Pouco a pouco vem então sendo instituída a estética do single, uma contraposição à primeira, “[...] representando, então, a preferência pelo consumo da música por unidade, em negação ao consumo obrigatório do álbum comercial” (CARVALHO; RIOS, 2009: 81).

O álbum tem sido dividido em faixas avulsas, comercializadas online. O usuário pode, então, ao invés de adquirir um álbum inteiro cujo interesse real se dava por duas ou três canções, adquirir agora somente as músicas desejadas.

O consumo por unidade, porém, não é recente. Nos anos 1950 já eram comercializados os compactos de vinil, ainda que inicialmente não por opção, mas por necessidade, como afirmam Carvalho e Rios:

Com o disco de goma-laca de 78rpm, a música também era consumida por unidade, mas isso por não haver alternativa, por não existir ainda um único suporte que comportasse em si mais músicas. Já o compacto, por outro lado, coexistiu com o álbum. Dentro desse contexto, o formato single tinha propósito e público alvo específicos. (2009: 81)

A insatisfação com o formato álbum já podia ser percebida desde o surgimento da fita cassete. Cativava os consumidores a possibilidade de, ao invés de ficarem limitados às escolhas das gravadoras, eles mesmos terem a liberdade de organizar suas playlists da forma que bem entendessem. E de certo modo o que o cassete representou para o vinil o MP3 representou para o $\mathrm{CD}$. Os $\mathrm{CDs}$ também são comercializados no formato álbum, e o MP3 
permite a manipulação das músicas de maneira prática e eficiente, realizando o mesmo processo que era feito com a fita cassete, só que agora de forma virtual e mais prática.

O produtor musical Pena Schimidt (2009) reconhece o fenômeno da fragmentação do álbum em faixas individuais, mas não crê que ele exista por si só:

Mesmo que se separem para a venda de faixa em faixa nas lojas de download (os discos), continuam sendo faixas que nasceram em um disco. Continuam sendo lançadas ao mundo dentro de discos, pois uma faixa só não tem impacto, não impressiona, não é? Pode ser, mas que o compacto, o single, já fez barulho, isso fez. (2009: 179)

A afirmação é real, mas em alguns pontos talvez questionável. É fato que os artistas e bandas continuem a lançar álbuns, e que não seja a prática predominante no mercado o lançamento isolado de um single. Afinal, muitos fatores comerciais e financeiros ainda estão ligados ao álbum. Um único single, por exemplo, não seria material suficiente para sustentar uma turnê. Outro fator a se considerar é o de que um álbum, quando lançado, oferece de imediato uma série de canções com potencial de se tornarem um hit, enquanto o lançamento de um single seria uma aposta bastante ousada do artista e produtores, pois caso essa música não emplacasse não haveria outra opção. Ao contrário, em um álbum se a música principal não se popularizar, ainda há diversas outras que podem cumprir esse papel.

O ponto questionável da afirmação de Schimidt é o de que as faixas são lançadas dentro de discos porque "[...] uma faixa só não tem impacto" (2009: 179). A canção "I gotta feeling", interpretada pelo grupo Black Eyed Peas, foi recentemente eleita a música mais vendida da história da iTunes Store ${ }^{89}$, com aproximadamente 16 milhões de downloads realizados até o final do ano de $2012^{90}$, enquanto o álbum da banda que contém essa faixa, intitulado "The E.N.D”, vendeu 11 milhões de cópias ${ }^{91}$. Isso mostra que a faixa comercialmente rendeu mais que o álbum, obtendo ela mesma um destaque maior que o do disco. Não se sabe até que ponto o álbum popularizou a música, ou se foi o sentido contrário, mas esses dados mostram que mais consumidores se interessaram pelo single do que pelo álbum, o que revela que uma faixa só pode sim ter um grande impacto, bem como uma significativa autonomia no mercado.

O pianista e compositor André Mehmari (2009) também questiona o formato single, e desaprova essa tendência, alegando que essa fragmentação fere a integridade da obra como um todo, entendendo aqui a obra sendo o álbum. Assim observa o autor:

\footnotetext{
${ }^{89} \mathrm{https}$ ///itunes.apple.com/us/playlist/most-downloaded-itunes-songs/id355046522

${ }^{90} \mathrm{http}: / / \mathrm{www}$.thetoptens.com/songs-black-eyed-peas/

${ }^{91} \mathrm{http}: / / \mathrm{www}$. rollingstone.com/music/albumreviews/the-beginning-20101130
} 
$\mathrm{O}$ formato de vendas de música faixa-a-faixa (inclusive em baixa resolução de áudio) não me agrada. Acho que fere a integridade do álbum como obra, como um livro que tem seus capítulos. Cada disco meu é como um livro que escrevi: não se deve alterar a ordem dos capítulos ou suprimir um ou outro. (2009: 209)

O autor compara um álbum com um livro, defendendo a ideia de que comercializar um álbum em faixas separadas seria como vender os capítulos de um livro separadamente, o que afetaria a integridade da obra como um todo.

Entretanto, há um ponto a ser discutido nessa afirmação. Mehmari considera o álbum como a "obra como um todo", a partir desse pressuposto condenando a comercialização individual das faixas. Porém, o que se percebe no fenômeno da comercialização dos singles é que o consumidor tem cada vez mais outorgado uma maior autonomia a eles, passando a considerar o próprio single "a obra como um todo". A partir do momento que o consumidor busca uma faixa individual e não o álbum, isso indica que para ele o que tem valor é unicamente aquela faixa, e não o disco inteiro. Para esse indivíduo a faixa por si só é a integridade da obra, e ele não se sente incomodado com a possibilidade de estar ferindo a totalidade do álbum, pois no fundo ele não valoriza o álbum, uma vez que se valorizasse o compraria, e não buscaria apenas uma faixa do mesmo.

A professora e pesquisadora da Universidade de Harvard Anita Elberse (2010) realizou uma minuciosa pesquisa acerca do que chama de "Efeito iTunes". Trata-se de um estudo sobre o impacto da comercialização de faixas individuais online contra a vendagem de álbuns inteiros.

Durante pouco mais de dois anos Elberse acompanhou a vendagem de mais de duzentos artistas, chegando à conclusão de que as pessoas tem comprado mais músicas do que costumavam até antes da instauração das vendas online. E o principal: essa vendagem aumentou porque os consumidores, ao invés de álbuns, têm preferido a adquirir faixas individuais. Elberse inicia seu artigo afirmando:

[...] com o advento de lojas online como a Apple's iTunes, a música agora é vendida na forma de faixas individuais ao invés de álbuns com uma dúzia ou mais de músicas, e os consumidores podem fazer o download de um episódio de uma série de televisão por vez ao invés de pagar pela temporada inteira em DVD. (2010: 1)

A autora estima que, durante seu estudo, para cada $1 \%$ de aumento de usuários que passam a adquirir músicas online, há uma diminuição de $6 \%$ na vendagem de álbuns. Enquanto parte desses números se deve à sucessão natural das mídias - nesse caso o abandono do CD para a instauração do MP3 - outra parte está ligada à questão financeira dos 
consumidores. Elberse observa as diferentes formas de oferta de um novo trabalho aos consumidores:

Em dezembro de 2006, a Interscope Records lançou o segundo álbum da popstar Gwen Stefani, The Sweet Escape, com doze músicas inéditas. Os fãs poderiam adquirir o produto de três formas: eles poderiam comprar o tradicional compact disc com as doze músicas por aproximadamente U\$ 14, fazer o download do álbum em formato digital de uma loja como a iTunes por U\$ 9,99 - ou escolher qualquer uma das músicas do álbum disponíveis para download que eles mais gostassem, cada uma sob o preço de U\$ 0.99. (2010: 4)

Enquanto para muitos o CD ainda seria a melhor opção devido ao encarte e suas demais particularidades, uma grande parcela opta pelo download individual das faixas, movida ou pela praticidade ou pela questão financeira, bastante discrepante entre um formato e outro.

Há ainda um outro fator significativo apontado por Elberse, este ligado ao prestígio do artista. A autora percebeu que um dos fatores que amenizam a queda nas vendagens de álbuns é o status do artista e sua legitimação no mercado musical. A fim de elucidar essa prática, o jornalista Scott Berinato descreve sua própria experiência:

[...] recentemente comprei o álbum do U2 'No Line on the Horizon' sem pensar duas vezes, mas quando aquela nova canção dos Avett Brothers me atraiu, não conhecendo muito bem a banda, preferi fazer o download apenas daquela música. (BERINATO, 2010)

Artistas já consagrados possuem um público vasto e uma legião de admiradores sedentos para apreciar seus novos trabalhos. Como o histórico de hits joga a favor, o público não deseja somente uma ou duas músicas, mas espera se surpreender com todas as canções inéditas, e por isso opta diretamente pelo álbum. Artistas desconhecidos, por outro lado, ainda não possuem essa confiança do público, fazendo com que o consumidor receie em investir em um álbum sem saber do real potencial e qualidade daquele material. E assim, por medo de arriscar, o consumidor opta apenas pela faixa que o agrada. A partir do momento que esse consumidor perceber que está a adquirir várias faixas individuais do mesmo álbum, isso pode transportá-lo para o patamar da confiança, tornando-o suficientemente seguro para no futuro investir diretamente no álbum desse artista.

A fragmentação se mostra, pois, como uma forte tendência já presente mas ainda com grande potencial de ampliação dentro de nossa sociedade, visto a aceitação que mostra possuir no que se refere à produção e consumo de música, e também à prática de escuta exigida nesse contexto. 
Fato é que a sociedade moderna já está acostumada à escuta fragmentada. Por um lado a escuta se torna bastante dinâmica, e o ouvinte é capaz de alternar entre repertórios diversos, em ambientes diversos, sem nenhuma dificuldade. Consegue acompanhar a transitoriedade da cidade, que se reflete na transitoriedade de sua playlist. Acompanha o dinamismo de um cotidiano mutante inserido em uma sociedade híbrida (GARCÍA-CANCLINI, 2006).

Por outro lado, este mesmo ouvinte se torna aos poucos incapaz de lidar com o todo, podendo enfrentar dificuldades ao escutar uma obra de maior duração do início ao fim. Está tão habituado a lidar somente com as partes que o interessam, que sofre ao lidar com o novo e com o indesejado. Escutar a $5^{\text {a }}$ Sinfonia de Beethoven do início ao fim, ou qualquer outra música pop com duração maior que seis ou sete minutos, pode se tornar um exercício de paciência, podendo vir a causar certo desinteresse nesse sujeito, que se estiver munido de seu iPod provavelmente avançará para a faixa seguinte após o tema inicial.

O sociólogo Richard Peterson (2005) utiliza o termo onívoro para descrever o usuário em cujo repertório de consumo encontra simultaneamente espaço para ópera e heavy metal, e pintura e programas populares de televisão.

Bauman relata parte de uma declaração pública de Stephen Fry, autoridade em tendências da moda e luz que ilumina a elite da sociedade londrina, que admite:

\footnotetext{
Bem, as pessoas podem ser loucas por tudo que é digital e ainda assim ler livros, podem frequentar a ópera, assistir a uma partida de críquete e reservar bilhetes para o Led Zeppelin sem por isso se segmentarem... Gosta de comida tailandesa? Mas o que há de errado com a italiana? Espere aí... calma. Gosto das duas. Sim. Isso é possível. Posso gostar de rúgbi e dos musicais de Stephen Sondheim. Do gótico vitoriano e das instalações de Damien Hisrts. De Herb Alpert com sua Tijuana Brass e das peças para piano de Hindemith. Dos hinos ingleses e de Richard Dawkins. Das primeiras edições de Norman Douglas e de iPods, sinuca, dardos e balé... (BAUMAN, 2013: 8)
}

A declaração de Fry ajuda-nos a compreender essa multiplicidade de gostos do usuário onívoro (PETERSON, 2005) do século XXI. Talvez isso justifique a necessidade de se carregar playlists inteiras impossíveis de serem escutadas na íntegra mesmo na maior das viagens. São muitos sabores diferentes apreciados, de modo que o ouvinte nunca saiba previamente qual prato desejará apreciar mais tarde e, por via das dúvidas, a melhor opção seria carregar todos.

A fugacidade tem se estabelecido como hábito, e o efêmero como modo de vida. E essa perspectiva salta na descrição do século XXI, que é continuamente alcunhado como uma era de rapidez, transitoriedade e mobilidade, de informação, de lucro, de relacionamentos e de tecnologia. Não se tem tolerância com as demoras. Não se tem paciência com o lento. 
Podemos inclusive refletir sobre a ideia de tempo, sobre a queixa de se ter a sensação que o relógio vem acelerando gradativamente, e que o tempo no século XXI está passando rápido demais. Sobre essa sensação, Valente (2004) observa:

\begin{abstract}
Na verdade, não se pode falar de aceleração de ritmos, quando o que acelerou, na verdade, foram as unidades de tempo, ou o andamento dos mais diversos ritmos - tomando de empréstimo essa precisa conceituação musical. O surgimento de máquinas capazes de trabalhar em maior velocidade possibilitou a execução de tarefas com maior rapidez: a produção industrial passou a ser realizada em uma duração de tempo menor, assim como a distribuição dos produtos, graças às facilidades nos transportes. Esse mesmo raciocínio pode ser aplicado aos produtos da mídia (os signos) e seus veículos (as mídias propriamente ditas). (2004: 195)
\end{abstract}

Não é, então, o tempo em si que acelerou. O que parece ocorrer é a realização de um número imensamente superior de tarefas em uma fração de tempo menor, gerando a impressão de um tempo acelerado. Se no início do século vivíamos em semibreves, hoje vivemos em semifusas, mas o andamento permanece o mesmo - tomando aqui o mesmo empréstimo da conceitualização musical.

García-Canclini (2006) também discorre a respeito de uma nova organização do tempo na sociedade moderna, quando diz:

\footnotetext{
Uma organização diferente do "tempo livre", que o transforma em prolongamento do trabalho e do lucro, contribui para essa reformulação do público. Dos cafés da manhã de trabalho, aos almoços de negócios, ao trabalho, para ver o que nos oferece a televisão em casa, e alguns dias aos jantares de sociabilidade rentável. O tempo livre dos setores populares, coagidos pelo subemprego e pela deterioração salarial, é ainda menos tempo livre por ter que preocupar-se com o segundo, o terceiro trabalho, ou em procurá-los. (2006: 288)
}

Após essas breves reflexões, espera-se compreender com um pouco mais de clareza a ânsia do ouvinte contemporâneo em ter todo seu repertório disponível em sua mídia portátil. Essa prática de escuta contemporânea apenas reflete o contexto e os valores da sociedade em que vivemos. A escuta requer tempo. A escuta requer silêncio. Quando não se tem tempo para escutar, negligencia-se parte da experiência que esta mesma escuta é capaz de proporcionar, ou ainda, se cria uma nova forma de escuta.

Pierre Boulez (2000) adiciona uma outra perspectiva a respeito do senso de aceleração do século XX, porém distinguindo essa sensação entre o campo científico e artístico:

Criamos a imagem de que nosso século (XX) tornou-se cada vez mais rápido. É possível que isto seja válido para a ciência, mas em geral, e em especial para as artes, o século XX constituiu o mais lento de 
muitos séculos. Exemplo: toca-se Erwartung, de Schoenberg, obra composta em 1909; e 90 anos depois ela continua ainda sendo uma peça problemática. (...) Nosso século é, repito, realmente muito, muito lento. (BOULEZ, 2000: 40 apud ADORNO, 2011: 19)

A partir dessa crítica podemos refletir não só sobre o modelo de escuta contemporâneo, derivado das mídias portáteis, mas também sobre uma possível lentidão no desenvolvimento da escuta ao longo do século XX. Seria a escuta fracionada da década de 2010 fruto de um desenvolvimento ainda imaturo, ou apenas um reflexo de uma sociedade que vive em um “ [...] tempo fracionado e neurastênico dos hiperlinks (...) em que se tem acesso a tudo e não se tem - ou não se quer ter - tempo para nada"? (MENEZES, 2011: 20 In: ADORNO, 2011: 20)

Sobre a mesma problemática do tempo, Flo Menezes conclui que "[...] na ilusão de se viver em um presto com fuoco, a sociedade e seu amadurecimento intelectual experimentam, na realidade, o andamento arrastado de um molto adagio" (2011: 20).

Em suma, a vida do indivíduo do século XXI parece ter sida fragmentada no âmbito social, econômico e cultural. Consequentemente, os produtos desses meios foram também fragmentados, promovendo o aprendizado de uma escuta musical de modo similar. As mídias de reprodução sonora traçam seu caminho evolutivo concomitantemente às tendências da sociedade, adequando-se a elas ao mesmo tempo em que interferem na construção das tendências futuras. E quando uma mídia muda, a forma de se escutar também muda. Se hoje a sociedade fragmentou-se, não haveria outro destino para a escuta senão a fragmentação.

Sinto-me em casa em qualquer lugar, embora não haja um lugar que eu possa chamar de lar (talvez exatamente por isso). Não é tanto o confronto de um gosto (refinado) contra o outro (vulgar), mas do onívoro contra o unívoro, da disposição para consumir tudo contra a seletividade excessiva. (BAUMAN, 2013: 9)

\subsubsection{Individualização}

A sociedade urbana do século XXI (com mais ênfase nas metrópoles) coexiste com inúmeros estímulos visuais, sonoros e sensoriais. Frente à agressividade de incessantes estímulos vinte e quatro horas por dia, sete dias por semana, é natural que em algum momento o indivíduo almeje um espaço para si, e só para si. Mas não somente um espaço geográfico privado, mas interior. Um momento de descanso, de desligamento das responsabilidades profissionais, da obrigatoriedade das relações interpessoais e da satisfação dada aos demais. 
Entretanto nem sempre isso é um impulso consciente e fruto de reflexão. Tampouco é sempre positivo, e gera reflexão. Pode-se facilmente isolar-se e não refletir, ou isolar-se sem o intuito específico de fazê-lo.

Simmel (1950) foi um dos primeiros sociólogos a discutir a importância da individualidade nas grandes cidades. Simmel fala sobre a necessidade do morador da metrópole de criar uma "bolha de individualidade", a fim de se preservar do fluxo das mudanças constantes que acomete os indivíduos de tal meio social. Afirma o autor:

Os problemas mais profundos da vida moderna derivam da demanda do indivíduo de preservar a autonomia e a individualidade de sua existência face às avassaladoras forças sociais, de herança histórica, das culturas externas e dos modos de vida. (1950: 409).

Em uma sociedade racional em que o intelectualismo e a matéria são o foco das atenções, e onde o indivíduo passa a agir "com sua cabeça ao invés do coração" (ibid: 410) pouco se considera o emocional. Simmel escreve:

Ao invés de reagir emocionalmente, o indivíduo metropolitano reage primeiramente de uma maneira racional. Desse modo a reação do habitante da metrópole aos eventos é movida a uma esfera de atividade mental menos sensível e mais afastada da profundidade da personalidade (1950: 411)

Bauman (2003; 2013) compartilha da mesma reflexão que Simmel, por vezes parecendo até um pouco pessimista ao observar o turbilhão sensorial envolto em interesses individuais:

Em nossos dias, é óbvio que não se pode mais sustentar seriamente qualquer esperança real de fazer do mundo um lugar melhor para se viver; mas nos vemos tentados a salvaguardar (da moda, do "progresso"), ao menos por algum tempo, aquele lugar relativamente agradável, privado, que se conseguiu construir para si mesmo nesse mundo. (2013: 28)

Como meio de defesa a esse bombardeio de estímulos, procura-se então limitar ao máximo a quantidade de relações interpessoais. E essa iniciativa já aponta diretamente para uma das funções da escuta em trânsito, conforme discutido no capítulo anterior.

\section{Os fones de ouvido e a privatização da escuta}

O som é uma das formas através das quais o habitante de uma metrópole é atingido diariamente. Mais do que atingido, muitas vezes agredido. As mídias portáteis podem 
funcionar como uma ferramenta de redução contra esses estímulos, como já discutido anteriormente. Entretanto, o isolamento que é geralmente atribuído às mídias portáteis na verdade é concretizado pelos os fones de ouvido, aparatos utilizados simultaneamente a esses artefatos. Um smartphone é capaz de reproduzir sons audíveis publicamente, assim como um tablet, um iPod, ou mesmo um antigo rádio portátil. A mídia portátil não torna a escuta restrita a seu usuário por si mesma, mas só se torna capaz de transformar uma escuta pública em privada através dos fones de ouvido.

É complexo, porém, o fenômeno da individualização causada pelo uso das mídias portáteis. Ao mesmo tempo em que tal fenômeno parece ser destrutivo para as relações interpessoais, ele também fornece meios de defesa ao ouvinte contra as agressões sonoras do ambiente e pode proporcionar convenientes momentos de reflexão. Talvez não haja medida certa ou errada, mas diferentes maneiras de se abordar a temática e experienciar o isolamento proporcionado pelas mídias portáteis, podendo esse ser benéfico ou prejudicial, conveniente ou inconveniente e comedido ou exagerado.

Para uma melhor compreensão a respeito do tema, pensemos na individualidade a partir de duas óticas: a da experiência pessoal e a da experiência compartilhada. Ou seja, a individualidade a partir do ponto de vista do usuário dos fones de ouvido e também a partir da interação estabelecida por ele com o ambiente externo.

Schönhammer (1989), assumindo inicialmente o papel de agente externo - aquele que não está escutando a mídia portátil, mas testemunhando seu uso por um terceiro - relata que seu impulso primeiro ao avistar um sujeito na rua com fones de ouvido era o de uma repulsa quase involuntária, um incômodo o qual não sabia nominar. Em meio a uma multidão, o ouvinte parecia chamar mais a atenção do que qualquer outro indivíduo que não estivesse portando aparelho algum. Porém, justifica sua atitude dizendo:

\footnotetext{
Muitas pessoas reagem da mesma forma que eu reagia. Elas julgam a pessoa com fones de ouvido como tola, infantil, imatura, ingênua, alheia, indisposta a se comunicar, egocêntrica, narcisista, autista, e assim por diante. (1989: 129)
}

A partir desse incômodo, Schönhammer se propôs a efetuar experimentos com o intuito de obter respostas mais palpáveis. Alguns, por exemplo, sugeriam que pessoas caminhassem primeiramente escutando suas mídias portáteis, e depois sem elas, relatando ao final a diferença entre as caminhadas.

O autor propõe que o estranhamento do indivíduo com fones de ouvido se dá pelo fato dele estar isolado. Ele não é diferente, mas se encontra isolado. E é esse isolamento que o 
transformaria em um estranho e comprometeria a relação entre os dois. Afinal, separação e isolamento são práticas comuns na vida comunitária, e todos os dias passamos por tais experiências nas ruas. Por que então o isolamento desse indivíduo seria problemático e incomodaria tanto? Para tentar responder essa pergunta, Schönhammer propõe uma situação: imagine alguém que passa pela rua com seu grande rádio portátil nos ombros e uma música tocando em alto volume. Talvez gostemos da música. Mais provável, talvez, seria reclamarmos do barulho. No primeiro caso nada faríamos em relação a ele. No segundo caso o consideraríamos antissocial. Mas ao contrário do indivíduo que usa fones de ouvido, aquele quebra barreiras invisíveis de separação ao invés de construí-las. O ouvinte com fones de ouvido habita em um mundo sonoro privado ao qual não temos acesso e tampouco podemos compartilhar. E isso pode ser justamente um dos fatores responsáveis pelo incômodo que o autor se refere. A respeito dessa impossibilidade de adentrarmos no universo sonoro alheio, ele observa:

Isso parece interromper uma forma de contato entre pessoas 'normais' que compartilham uma experiência mútua, mesmo se nela não há comunicação explícita alguma. As pessoas com fones de ouvido parecem violar uma lei não escrita de reciprocidade interpessoal: a segurança da presença consensual comum em situações compartilhadas. (1989: 130)

Em outras palavras, Schönhammer afirma que no caso do sujeito com um rádio em mãos, ainda que possa ser estabelecida uma situação não agradável de invasão sonora, alguma relação é estabelecida. No caso do ouvinte com fones de ouvido, não há compartilhamento algum de uma experiência que deveria naturalmente ser compartilhada. E essa privação é causa de desconforto. $\mathrm{O}$ estar excluído do universo alheio parece incomodar, pois uma prática humana tradicional - a da partilha - é violada.

Hosokawa (1984) corrobora essa ideia ao discorrer sobre o Walkman:

$\mathrm{O}$ que surpreendeu as pessoas quando viram o Walkman pela primeira vez em suas cidades foi o fato evidente de que se podia perceber que o ouvinte estava escutando alguma coisa, mas não se sabia o quê. Alguma coisa havia ali, mas escondida: era um segredo. Até o aparecimento do Walkman as pessoas não haviam testemunhado uma cena em que um passeante 'confessava' possuir um segredo de forma tão distinta e óbvia. (1984: 177)

Novamente a curiosidade não-sanada parece incomodar e contraria a suposta lógica de reciprocidade social. Schönhammer conclui:

Alguém lendo um jornal em um metrô não nos irrita da mesma forma que alguém com os ouvidos tampados com fones. A natureza nos provê pálpebras para fechar os olhos, mas nada para fechar os 
ouvidos. Óculos escuros, também, podem irritar. Mas a irritação, nesse caso, ocorre devido ao desequilíbrio proporcional entre o gesto de olhar e ser olhado. (1989: 133).

O universo aparentemente impenetrável do ouvinte pode ser percebido, pois, como um dos fatores responsáveis pelo incômodo diante da utilização das mídias portáteis, ao menos por quem está do lado de fora dos fones de ouvido.

\section{Perspectiva interna}

Prosseguimos agora sob a perspectiva interna da escuta passeante, isto é, sob o ponto de vista de quem está entre os fones de ouvido.

Alguma reflexão já foi realizada no capítulo anterior a respeito dos motivos por trás da utilização de uma mídia portátil. Funções como o controle ambiental, o controle do estado de espírito e a demarcação de território já demonstraram parcialmente o ponto de vista do ouvinte. Prosseguiremos tentando manter o foco na individualidade do ouvinte, e no suposto isolamento que as mídias portáteis proporcionam.

A primeira perspectiva importante de ser analisada é a divisão de ambientes gerada a partir do momento que os fones de ouvido são colocados. Haja grande ou pequena interação na relação ouvinte-ambiente, uma separação é ocasionada, e a fruição dos estímulos passa a ser diferente quando as frequências começam a pulsar dentro dos fones. Uma nova experiência multissensorial acontece, e toda a interação passa a ter uma nova perspectiva tanto para o ouvinte quanto para os demais à sua volta.

Schönhammer (1989) descreve esse fenômeno como um momento em que "[...] a relação objeto-mundo é alterada para o ouvinte" (1989: 133), uma vez que "o espaço habitado perde sua familiaridade, isto é, de alguma maneira é dividido em duas partes. O ambiente familiar o qual aquele indivíduo conhece e pertence se torna subitamente estranho quando é separado de sua porção acústica" (idem).

Ou seja, a partir do momento em que o ambiente físico no qual o ouvinte se encontra é separado do aspecto acústico do mesmo, cria-se a perspectiva de dois ambientes distintos, um físico sobreposto a outro acústico, ocasionando ao ouvinte uma "sensação concomitante de presença e ausência" (ibid: 134). Esta é a base de todas as funções musicais supracitadas no capítulo anterior. A partir dessa divisão se estabelece uma maior ou menor interação, pautada muitas vezes em intenções específicas do ouvinte, que resultará nas diferentes funções da escuta itinerante. 
Não é possível afirmar categoricamente o grau de isolamento que o ouvinte se encontra quando escuta através de seus fones de ouvido. Muitos fatores influenciam nessa resultante, entre eles o volume da mídia, a vontade do ouvinte em interagir com o ambiente externo, a concentração do ouvinte no material sonoro, o grau de ruídos externos etc.

Alguns autores, como Adler (1999) e Negus (1992) acreditam ser possível um total isolamento e anulação do meio externo por parte do ouvinte. Outros, como Chambers (1994), Lind (1989) e Chen (1993) advogam por uma escuta privada, que pode ser limitada ou até certo ponto controlada, mas não completamente capaz de aniquilar o ambiente exterior. Chambers afirma que "cada ouvinte seleciona e rearranja a paisagem sonora ao seu redor e, a partir da construção de um diálogo com ela, deixa uma marca nesse espaço” (1994: 50).

Um simples vazamento de som pelos fones de ouvido, por exemplo, já caracterizaria uma interação entre o usuário e os demais ao seu redor. Seria, na realidade, uma experiência ambivalente, sendo ao mesmo tempo uma interação privada e pública, compartilhada e solitária.

Connor (1999), ao discutir sobre as interações do ouvinte com o ambiente afirma:

[...] a experiência do Walkman, a intoxicação do Walkman, vem do fato de que, para o usuário, ele não está abstraído do local pelo qual ele caminha, ou do metrô que está sentado. O ouvinte do Walkman está frequentemente abrindo espaço para uma oportunidade de integração entre os sons recebidos, sobre os quais possui controle, e os sons externos que está escutando. (1999: 308)

Ou seja, para Connor a experiência de se ouvir em público não é solitária, mas permite a integração com o ambiente. Assim também relata um dos entrevistados de Schönhammer, um jovem afegão que residia na Alemanha:

Eu já conheço o Walkman há algum tempo. Eu o usei pela primeira vez durante as férias na Espanha. Lá eu o utilizei a todo momento. Só consigo expressar meus sentimentos subjetivamente. Quando eu uso esse aparelho eu me sinto muito bem, como em um concerto. Nada me distraia desse concerto. $\mathrm{O}$ concerto se passava dentro de minha cabeça. No entanto, não me sentia completamente isolado. Posso fazer contato com outras pessoas a qualquer momento, mas também posso me defender de qualquer um no instante que desejar. (1989: 134)

Tais afirmações, especialmente a última, vinda de um usuário assíduo das mídias portáteis, comprovam a maleabilidade da escuta em trânsito, e a margem que fornece ao ouvinte para que esse tenha prazer na escuta ou a utilize como "arma" quando lhe aprouver.

$\mathrm{Na}$ tentativa de se isolar do ambiente externo, um dos recursos mais comuns por parte dos usuários é aumentar o volume da mídia. 
Como já visto na função de controle ambiental, usuários de metrôs podem recorrer a esse recurso na tentativa de evitar a exaustão psicológica da exposição prolongada aos ruídos. Outros podem se aproveitar da intensidade do volume para fins profissionais. Seria o caso de um trabalhador de escritório que ao utilizar seu computador para trabalhar, conecta seus fones, escolhe uma canção familiar e a executada em alto volume, a fim de se ausentar dos ruídos do escritório e ser capaz de se concentrar em seu ofício. Sua produtividade poderá ser beneficiada, uma vez que ele estará alheio às conversas externas, que, caso não estivesse com os fones a postos, poderia querer participar, se desviando de suas obrigações.

Para Schönhammer, existem dois motivos que justificam a habitual prática de se escutar música em alto volume nos fones de ouvido: o primeiro seria a possibilidade de se ouvir em volume alto sem incomodar os demais, e o segundo seria a constatação de que ouvir em volume alto, segundo alguns psicólogos especializados em música, aumenta a satisfação do ouvinte e o prazer em ouvir (1989: 135).

O autor também aponta uma controversa realidade de se ouvir o som alto. Alguns experimentos de campo revelaram que, ao mesmo tempo em que a atenção à música cresce, aumenta também a atenção (e diminui a tolerância) para os sons externos. Em outras palavras, o ouvinte fica mais atento a qualquer som "intruso" que venha a atrapalhar sua experiência de escuta. Assim, um som de um automóvel que seria naturalmente ignorado na ausência de fones de ouvido, se escutado por um indivíduo concentrado na alta música de seus fones, se destaca, o incomodando muito mais, parecendo inclusive um ruído mais intenso do que é. O que mudou não foi o som em si, mas o contexto, pois em um ambiente ele era paisagem sonora, no outro ele é intruso. A lógica é simples: se um ouvinte ouve com seu volume no máximo, provavelmente a maioria da paisagem sonora externa será anulada, de forma que os poucos sons que conseguirem penetrar essa barreira serão facilmente detectados, como se os ouvidos desse usuário estivesse mais sensível aos sons indesejados.

Estabelece-se assim um paradoxo: quanto mais alto estiver o volume dos fones de ouvido, mais sensível estará a escuta para os sons ambientes. Consequentemente, quanto maior o esforço do ouvinte para fugir dos ruídos externos, maior a chance de identificá-los. Schönhammer prossegue o discurso unindo o paradoxo do alto volume e a problemática da curiosidade insaciada na escuta privada:

Não é absolutamente verdade que ouvir um Walkman em um volume alto não incomoda os demais. Pelo contrário, alguns dos entrevistados relataram sentir mais agressividade quando ouviam sons vazando dos fones dos usuários. Eu acredito que essa reação não seja desencadeada pelo mero efeito acústico do som percebido, mas pelo fato de que o 
que se ouviu foi somente o "resto" do universo sonoro de alguém.

(1989: 135)

Dessa forma, o autor retoma a ideia de que quando somos privados de participar e nos envolver com o universo sonoro do outro nos sentimos em algum grau lesados, e temos certa dificuldade em lidar com isso, dificuldade muitas vezes demonstrada ou exteriorizada por sentimentos involuntários, como nesse caso, a raiva.

\section{Autonomia e protesto}

Um dos atrativos das mídias portáteis é a autonomia que ela dá a seus usuários. Essa autonomia vai desde a escolha do repertório até a imposição que o ouvinte pode estabelecer sobre uma paisagem sonora indesejada.

Já o protesto está ligado à subversão que o ouvinte pode estabelecer frente a seus inimigos, sonoros ou não. Rey Chow (1999) discute a escuta nômade a partir de uma subversão do ouvinte perante os poderes autoritários que se impõe contra ele. Para a autora, uma escuta privada funciona como "uma 'sabotagem' silenciosa da tecnologia de coletivização com seus próprios instrumentos" (1999: 475), sendo assim uma forma de ação social ou mesmo política. Para Chow, essa subversão vai contra os regimes opressores aos quais os ouvintes estão expostos, e afirma que, como a escuta é individualizada e privada escondida - ela “[...] conduz a uma certa liberdade. Essa é a liberdade de se estar surdo para os alto-falantes da história" 92 (1999: 475).

Para Chow, o que aparentemente seria uma prisão pode na realidade ser a liberdade. Os fones de ouvido não seriam simplesmente um escudo, como afirma Eisenberg (1998), mas muito mais que isso, seriam uma ferramenta ativa de exercício da liberdade, um instrumento através do qual o ouvinte poderia fazer política e vencer as forças opressoras.

Trata-se de uma espécie de jogo de poderes entre o ouvinte e o ambiente externo (seja esse os barulhos ou as próprias forças políticas). E o poder do usuário das mídias portáteis está justamente nos seus fones de ouvido. Através deles ele pode refugiar-se em um universo interior ao mesmo tempo em que sabota as imposições externas que o forçam a voltar sua atenção a elas. A respeito dessa briga de poderes, a musicóloga Heloísa Valente observa:

As consequências da proliferação do ruído - o barulho - foram indubitavelmente determinantes no que diz respeito aos modos de

\footnotetext{
${ }^{92}$ A autora, chinesa, aqui se refere à China comunista, em que a propaganda governamental era transmitida através de alto-falantes.
} 
ouvir, pois promoveram uma mudança perceptiva, decorrente de uma sensibilidade diferenciada cuja origem se encontra na transformação da paisagem sonora, segundo Schafer, de hi-fi para lo-fi. (...) O desejo de dominação pelo barulho também pode ser saciado por indivíduos isolados em grupo, pois fazer barulho é, antes de tudo, chamar a atenção. Assim sendo, comícios, apresentações de rock, motocicletas que chispam com o escapamento aberto, automóveis que desfilam com os alto-falantes do rádio em alta intensidade nada mais são do que tentativas, geralmente bem sucedidas, de atingir esse objetivo, embora nem sempre claro e consciente. (1999: 33; 45)

Podemos compreender a escuta itinerante como uma subversão a essas agressões. A partir do momento que o ouvinte não se permite dominar pelo barulho de caráter opressor de pessoas ou grupos externos, ele transcende o ato de ouvir como puramente musical, transformando-o também em uma atitude política, como afirma Williamson (1988) ao se referir ao Walkman como um aparato que "produz um som privado em um ambiente público; uma arma do indivíduo contra o público" (1988: 210).

Simun (2009), em sintonia com a manifestação de Chow (1999), descreve a reação de enfrentamento do usuário contra as imposições externas dizendo que “[...] em uma cidade repleta de mensagens midiáticas - de anúncios de metrô a comerciais de TV impressos em ônibus [...] o MP3 permite que seus usuários, de alguma forma, 'silenciosamente sabotem' a dominação da cultura de massa" (2009: 940), e conclui afirmando que "[...] ao escolher se desengajar do ambiente sonoro dos lugares comerciais, os usuários de MP3 impõe o controle configurando seus próprios comportamentos e ações" (idem).

A professora suíça Regina Bendix (2000) discorre sobre esse paradoxo em que o ouvinte das mídias portáteis se encontra quando lidando com as forças do ambiente:

[...] o coletivo social não desaparece durante essa manobra pessoal (escutar o Walkman para bloquear os barulhos externos) por parte do indivíduo. Em algum momento, forças superiores às do indivíduo podem invadir sua cuidadosa experiência de controle estético, e essa fragilidade estratégica continuamente lembra esse indivíduo dos poderes - sociais e tecnológicos - que controlam seu ambiente. (2000: 38)

Bendix, assim como Chambers (1994) e Chow (1999) acredita não ser possível um isolamento completo do ouvinte, por isso propondo reflexões acerca da relação estabelecida entre as duas partes.

O filósofo americano Crispin Sartwell (1999), ao analisar o caráter social das mídias portáteis, nesse caso o Walkman, primeiramente discorre sobre o senso comum, de que essas mídias isolam o indivíduo, inserindo-os em seu reduzido espaço sonoro e desconectando-os 
das pessoas ao redor. Para muitos, o Walkman inaugurou "uma sombria nova era de isolamento: somente você e sua máquina" (1999). Mas logo na sequência, prossegue discordando desse senso comum:

O Walkman possui sim um aspecto social. Mesmo que nos separando de outras pessoas, eles também são ferramentas que nos conectam aos outros. O Walkman é, acima de tudo, um veículo para a mídia de massa, esteja você ouvindo Dixi Chick ou esportes no rádio. (1999)

Parece complicada a divisão entre o que é público e privado quando se fala de escuta musical. Quais seriam esses limites em situações como a escuta em trânsito, em que o ouvinte experimenta ambos os lados simultaneamente? Talvez por essa razão Bull (2001), quando se referindo ao "local" em que o ouvinte se encontra no ato da escuta em deslocamento, parece julgar inadequados tanto o termo público quanto privado. Para ele, a alternativa sugerida seria referirmo-nos à experiência da escuta nômade simplesmente como uma experiência urbana tecnológica (2001: 211).

\section{Portabilidade e solidão}

Até o presente momento esse trabalho abordou a prática da escuta em trânsito e as relações estabelecidas entre o ouvinte e o ambiente exterior, bem como as funções de utilização da mídia portátil. Porém é igualmente relevante a discussão acerca do resultado dessa escuta no âmbito psicológico dos ouvintes. Afinal, seria correto afirmar que essas mídias contribuem para a solidão dos ouvintes?

Simmel (1950) já falava a respeito da necessidade dos habitantes metropolitanos em achar seu próprio espaço em meio ao bombardeio de estímulos urbanos. Uma das maneiras encontradas para se estabelecer esse limite foram as mídias portáteis, pois através delas o usuário adquire um leque de possibilidades de interação (ou não-interação) com o ambiente que o circunda.

No entanto, a radicalidade nesse "ausentar-se" pode ocasionar também um problema, exatamente contrário ao primeiro. Ou seja, a fim de diminuir o contato com os estímulos exacerbados do cotidiano, o indivíduo se fecha em seu universo, restringindo suas relações interpessoais a um patamar próximo do patológico.

Robert Crane (2005), estudioso da psicologia, desenvolveu uma pesquisa relacionando a utilização de aparatos portáteis de apreciação musical com o chamado "distanciamento 
social" 93 e solidão. A pesquisa consistiu basicamente em reunir um grupo de jovens estudantes em idade universitária e pedir para que cada um monitorasse por um período determinado a quantidade de horas por dia (e posteriormente por semana) que gastavam escutando sua mídia portátil. A constatação foi a de que o isolamento social se mostrou significantemente maior em usuários mais assíduos de tais mídias do que em usuários moderados ou que pouco se utilizavam dessa tecnologia.

Não somente as relações interpessoais parecem ser afetadas pelo advento das mídias portáteis, mas a popularização dos fones de ouvido pode também estar revelando uma maior separação psicológica entre os indivíduos (MOEBIUS e ANNEN, 1994). Esses autores, assim como Rosen (2005), acreditam no impacto que os smartphones e demais gadjets possam ter no processo de individualização. Rosen escreve:

[...] porque o iPod é uma tecnologia portátil, assim como o telefone celular, ele ele tem um impacto no espaço social que nem mesmo o TiVo teve. Aquelas pessoas com os fios brancos pendurados no pescoço parecem estar apreciando sua exclusiva trilha sonora, mas também estão praticando a "presença ausente" em espaços públicos, prestando pouca atenção, se alguma, no mundo exatamente ao seu redor. (1995: 66)

Moebius e Annen (1994) sugerem que um dos motivos que justificaria tão grande apego às mídias portáteis seria a do conforto e segurança que elas proporcionam a seus usuários. Assim como um "cobertor de estimação" para uma criança, esses gadjets seriam o conforto para seus usuários. Em ambas as situações o indivíduo carrega seu objeto de proteção consigo para aonde vai, a fim de se proteger das ameaças que pode encontrar. $\mathrm{O}$ "cobertor de estimação da criança [...] e o Walkman servem como uma distração contra as demandas do dia a dia" (1994: 576).

Talvez isso explique parcialmente a necessidade dos ouvintes contemporâneos de estarem sempre com suas mídias em mãos. O pavor encontrado em alguns indivíduos, que percebem no percurso para o trabalho que esqueceram o smartphone em casa, parece ilustrar com certa clareza essa insegurança, de maneira que esse indivíduo parece se sentir vulnerável, ou mais exposto às intempéries e monotonias do dia, sem a companhia de seu gadjet.

Bull (2005) observa:

Os iPods tendem a ser não-interativos ao passo que os usuários constroem fantasias e preservam um sentimento de segurança precisamente por não interagir com os demais ou com o ambiente. [...] os iPods são utilizados tanto como um acompanhamento mundano do

\footnotetext{
${ }^{93}$ Termo utilizado pelo próprio autor em sua pesquisa.
} 
dia-a-dia quanto como uma forma de estetizar e controlar sua experiência. (2005: 350)

Para Bull, estar com o iPod significa ter a opção de interagir ou não com os demais, bem como ter em mãos a segurança de poder fugir de situações embaraçosas ou indesejadas. Da mesma forma, estar desprovido do aparelho pode significar estar exposto às situações cotidianas, o que justificaria o sentimento de insegurança do usuário.

O sociólogo Thomas Scheff (2004) define uma interação saudável entre os indivíduos como:

[...] um equilíbrio entre o 'eu' e o outro. O indivíduo se identifica e partilha com o outro assim como o faz consigo mesmo, não menos e não mais. [...] A ênfase do Ocidente no indivíduo autossuficiente é um impulso cultural rumo ao isolamento, ao invés de laços seguros. Se da mesma forma alguém projeta ênfase demais no(s) outro(s), os laços também não são seguros. (2004: 12)

Michael Lerner (1986) também discorre sobre a solidão, e as facilidades encontradas pela sociedade em adentrar nesse redemoinho:

[...] nossa sociedade cria um leque de condições nas quais as pessoas estão sempre sendo abandonadas, e nas quais é extremamente difícil se encontrar a força necessária e essencial para manter uma saúde psicológica apropriada. Os seres humanos precisam uns dos outros, e nossa mais profunda essência se dá no relacionamento com o outro (1986: 176)

Partindo desse pressuposto, podemos inferir que independente do grau de envolvimento com a escuta, a partir do momento em que fones de ouvido são colocados, a interação social já é em algum nível comprometida. Conforme o envolvimento do indivíduo com sua mídia, e a intensidade de sua utilização, essas relações com os demais podem adquirir um grau de gravidade maior ou menor.

Essa firmação de Lerner vai diretamente ao encontro da conclusão de Craner (2005), que constatou um maior nível de distanciamento social entre os usuários assíduos das mídias portáteis.

O cientista social Robert Weiss, na obra Loneliness: The experience of emotional and social isolation (1973) explora dois tipos de solidão: a solidão social e a solidão emocional. A solidão social poderia ser descrita como a sensação de estar separado dos demais, enquanto a emocional poderia ser descrita como o a experiência de sentir falta do contato com o outro. A solidão social pode ter como causa a falta de engajamento na sociedade, enquanto a solidão 
emocional pode ser fruto da incapacidade de se ter intimidade, ou proximidade emocional com alguém.

As mídias portáteis poderiam contribuir para qualquer um dos tipos descritos por Weiss de solidão. Ao mesmo tempo em que intimidam as relações interpessoais diretas em um ambiente público, distanciam o ouvinte da possibilidade da criação de laços emocionais com os indivíduos ao redor.

No capítulo anterior foi apresentado um par de fones de ouvido ${ }^{94}$ que, trabalhando com a tecnologia de noise cancelling se propunha a reduzir os ruídos externos. Enquanto os dois primeiros modos de funcionamento tinham como foco a diminuição de ruídos para que a atenção do ouvinte permanecesse na música escutada, um terceiro modo era direcionado para os momentos em que o usuário busca por tranquilidade e silêncio. Ou seja, os fones de ouvido não serviriam de alto-falantes privados, mas simplesmente de tapumes contra os estímulos externos, fazendo do ouvinte algo mais semelhante a um "não-ouvinte".

Aqui mora um paradoxo notável: um acessório midiático desenvolvido para não transmitir estímulo algum, mas apenas para privar dos sons. Mais ainda, um fone de ouvido, cuja função principal é injetar os sons diretamente dentro do ouvido do usuário (para que esse ouça com o máximo de clareza possível), comercializado para um ouvinte que não quer ouvir som algum, e o utiliza desconectado de qualquer mídia.

O fone de ouvido parece estar criando uma autonomia, e se independendo aos poucos das mídias às quais está - e sempre esteve - vinculado. Ora, até então, qual a utilidade de um fone de ouvido desplugado do transmissor do conteúdo sonoro? A multifuncionalidade, característica dos gadjets, vagarosamente pode estar migrando também para seus acessórios, sinal de que os anseios por novidade ainda caminham a passos largos na sociedade do século XXI.

Essa autonomia, porém, permeia a ambiguidade, uma vez que enquanto por um lado o fone serve como ferramenta ultrassofisticada a favor da clareza e pureza sonora sem interferência de sinais, por outro é um acessório perfeitamente adequado para quando se deseja o silêncio absoluto ${ }^{95}$. Seja sob qual funcionalidade o ouvinte deseje usufruir, os fones ainda parecem ser imbatíveis na função de agentes potencialmente efetivos na promoção do distanciamento social e solidão.

\footnotetext{
${ }^{94}$ ATH-ANC9 QuietPoint, da empresa japonesa Audio Technica.

${ }^{95}$ Esse trabalho não pretende adentrar no âmbito das discussões a respeito da existência ou não do silêncio absoluto. O termo aqui é empregado com a simples finalidade de expressar uma ideia geral e dentro de um contexto específico.
} 
Mas tal consequência - a solidão - parece não ser exclusiva das mídias portáteis, mas uma resultante mais ampla de uma sociedade seduzida pela cibercultura e seus subprodutos.

O psicólogo social Robert Kraut, juntamente com uma equipe de pesquisadores, desenvolveu uma pesquisa relacionando a utilização da internet no ambiente familiar ao distanciamento social entre seus integrantes. Durante dois anos as famílias foram observadas para que houvesse uma comparação entre o antes, o durante e o depois de um período de dois anos conectada on-line. A conclusão foi de que inicialmente a internet era utilizada para a comunicação com terceiros. Entretanto, a comunicação entre os membros da família, bem como as atividades externas de engajamento social, diminuíram, ao passo que a depressão e a solidão aumentaram. (KRAUT et al, 1998).

Bull (2005) descreve esse fenômeno quando afirma que “[...] não as ruas, mas nossas casas - e cada vez mais nossos quartos - tornaram-se empórios de prazeres visuais e sonoros" (2005: 345). Sonia Livingstone também alerta para a forma e a intensidade do consumo de mídia dentro dos lares, observando que os adolescentes tem a cada dia mais apreciado o consumo privado. A autora relata que o lar tem se tornado gradativamente o lugar preferido para o consumo de uma mídia individual, com crianças gastando a maior parte do tempo que utilizam suas mídias, sozinhas em seus quartos (LIVINGSTONE, 2002 apud BULL, 2005).

A mesma autora fala ainda sobre a "cultura do quarto", aliando esse espaço à privatização da utilização das mídias. Para Livingstone, a segunda metade do século XX foi acometida por mudanças que aumentaram significativamente a importância dos quartos para as crianças e adolescentes, tornando estes locais apropriados para o lazer e auto-aprendizado. Entre as mudanças estão as alterações de padrões de interação familiar, redução no tamanho das famílias, emergência de uma cultura jovem e o poder de consumo das crianças e jovens (LIVINGSTONE, 2001).

Outro aspecto levantado pela autora é o de que os quartos das crianças e jovens europeus englobados em suas pesquisas são altamente equipados com tecnologias de mídia. Juntamente com objetos tradicionais, como livros e rádios, essas crianças possuem também televisões, smartphones, computadores e vídeo-games, muitos dos quais interligados entre si ou conectados a outros equipamentos da casa.

Com a intensificação das campanhas publicitárias focada nesse público, os quartos das crianças de classe média alta "se tornaram tanto um local de recepção de mensagens

\footnotetext{
${ }^{96}$ Bedroom culture, no original. Em artigo intitulado Bedroom culture and the privatization of media use Moira Bovill e Sonia Livingston descrevem de forma detalhada a individualização de crianças e jovens a partir da "cultura do quarto", apresentando dados empíricos que revelam o apreço desses indivíduos pelos próprios quartos e os aparatos midiáticos que ali usufruem.
} 
comerciais quanto um local de amostra e utilização de bens de prazer" (LIVINGSTONE; BOVILL, 2001: 2). Assim, parece existir uma pré-disposição à individualidade na sociedade contemporânea, em que desde criança os indivíduos são acostumados a estarem sozinhos, a se divertirem sozinhos e a se relacionarem virtualmente, muitas vezes, inclusive, com os próprios familiares.

Em suma, a individualização é uma realidade do século XXI que pode ser facilmente ampliada pelas mídias portáteis e os fones de ouvido, estejam esses trabalhando em conjunto ou separadamente. Soma-se a essa individualização a já discutida transitoriedade da sociedade contemporânea. A resultante é um indivíduo que cada vez mais caminha entre lugares e nãolugares ${ }^{97}$, em “[...] um mundo assim prometido à individualidade solitária, à passagem, ao provisório e ao efêmero..." (AUGÉ, 1994: 74).

\footnotetext{
${ }^{97}$ Termo utilizado por Marc Augé na obra Não-Lugares: Introdução a uma antropologia da supermodernidade, de 1994. Refere-se a um espaço "que não pode se definir nem como identitário, nem como reacional, nem como histórico" (p. 73). Ou seja, lugares de transitoriedade, como aeroportos, hotéis e mercados, onde o definitivo não encontra espaço.
} 


\section{Considerações finais}

Esta é apenas uma parte da complexa teia de elementos sociais, tecnológicos, pessoais e musicais à qual nos deparamos ao estudar este modo de escuta aqui proposto, a escuta itinerante; em movimento. Esta escuta, por sua vez, se apresenta como fruto de um desenvolvimento tecnológico e mudanças sociais ainda a desabrochar nesse início de século XXI. Aspectos como a ubiquidade, a fragmentação e a individualização são claros e crescentes em nossa sociedade, seja no marketing ou na vida familiar.

Podemos declarar que já adentramos na era pós-CD, em que, a cada dia mais, sua vendagem e circulação diminuem, cedendo lugar a aparelhos menores e com maior capacidade de armazenamento. Esses aparelhos oferecem uma tecnologia bastante superior em termos de multifuncionalidade, se tornando mais sedutores e apropriados para o ritmo de vida desses primeiros anos do século XXI. E essa multifuncionalidade se justificaria diante de uma sociedade de cidadãos polivalentes, também "multifuncionais".

Com a dominação das mídias portáteis, nossos corpos cederam espaço a nossos dedos, fazendo desses os grandes protagonistas dessa era virtual, conforme observa Iazzetta:

Sem nos darmos conta, transferimos nossa sensibilidade mecânica do mundo e do corpo para a ponta dos dedos, que se ocupam em manipular toda a diversidade de aparelhos que nos circundam a partir de minúsculas interfaces com as quais ligamos e desligamos coisas, criamos obras de arte e nos comunicamos com o mundo. (2006: 1239)

E finaliza:

A relação com o botão concentra toda a tensão reprimida de nossos corpos, tão comportados que ficam em nossas cadeiras de escritório, aparelhos de ginástica, ou salas de concerto. Agora são os dedos que exprimem nossos gestos, nossas tensões, nosso espanto (2006: 1239).

As mídias simplesmente acompanham o ritmo e as tendências do desenvolvimento cultural, político e tecnológico de uma sociedade. Estando esses fatores em constante mutação, é natural a constante atualização e substituição dessas mídias, e estando a escuta diretamente vinculada às mídias, também parece natural que essa se encontre também em um contínuo processo de adaptação e desenvolvimento.

Entretanto, mais do que mudanças exclusivas relacionadas à experiência da escuta musical, essa maneira itinerante de se ouvir apresenta desdobramentos também de cunho 
social, influenciando na forma de se pensar e comportar do cidadão metropolitano do século XXI.

Esse trabalho pretendeu fornecer reflexões acerca da escuta musical sob um viés diferenciado, em uma área de estudos ainda em expansão - a escuta musical fundada na utilização das mídias portáteis presentes na transição entre os séculos XX e XXI. A temática abordada possibilita ainda um significativo diálogo multidisciplinar com trabalhos de áreas como a Comunicação e a Sociologia.

Por último, a presente dissertação servirá também como uma nova fonte de pesquisa para a musicologia, tratando de um assunto bastante em voga e que aponta continuar se expandindo pelo segundo decênio do século XXI.

Concluindo, cabe-nos, como ouvintes atentos, estarmos alertas do contexto ao qual pertencemos - descrito ao longo desse trabalho - para que não sejamos vitimados pelos excessos da modernidade; mas ao contrário, aproveitemos das oportunidades que era da conectividade, em suas possibilidades plurais, com consciência e ouvidos clariaudientes, como já preconizava Schafer desde a década de 1970, mediando assim o futuro de nossa escuta. 


\section{Figuras}

Figura 1: Capa do álbum Slug Line, de John Hiatt (1979)

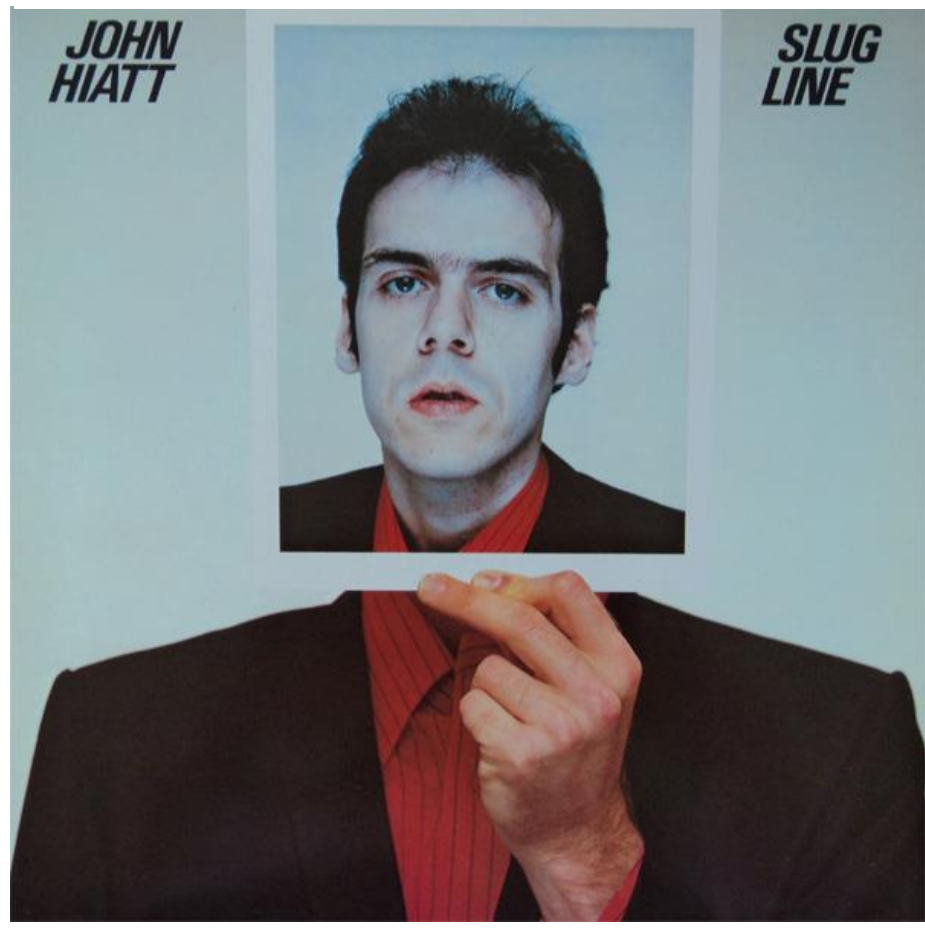

MCA Records, Holanda. Direção de Arte: John Van Hamersveld. Foto: Nick Rosza

Figura 2: Sleeveface com capa do álbum True Blue (1986), de Madonna.

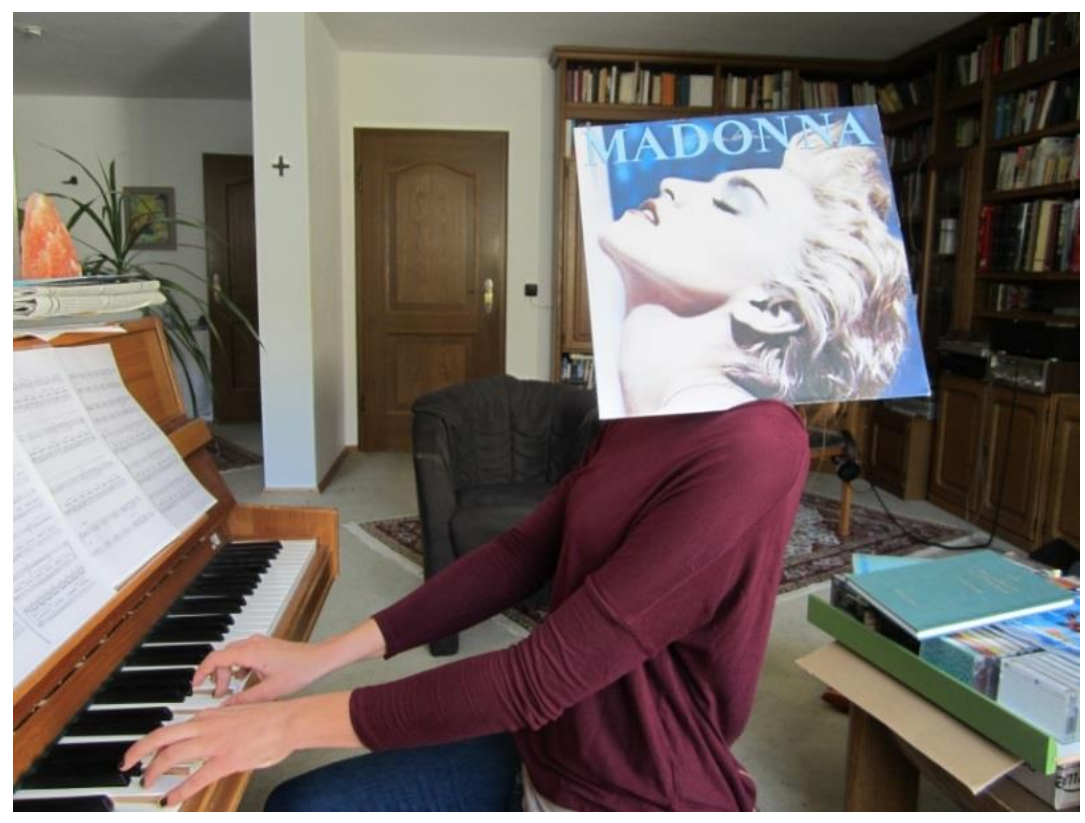

Crédito: Luise Peeck 
Figura 3: Great Sony Walkman TV and Print Ads of the 1980s. Anúncio Walkman 1980s.

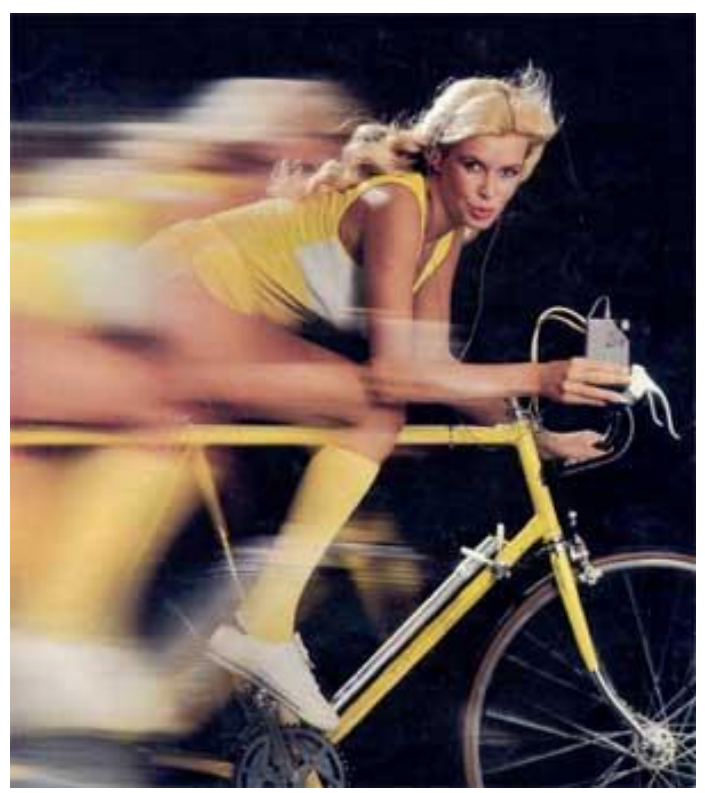

Crédito: Rothman Wilson

Figura 4: Anúncio Walkman (1980s)

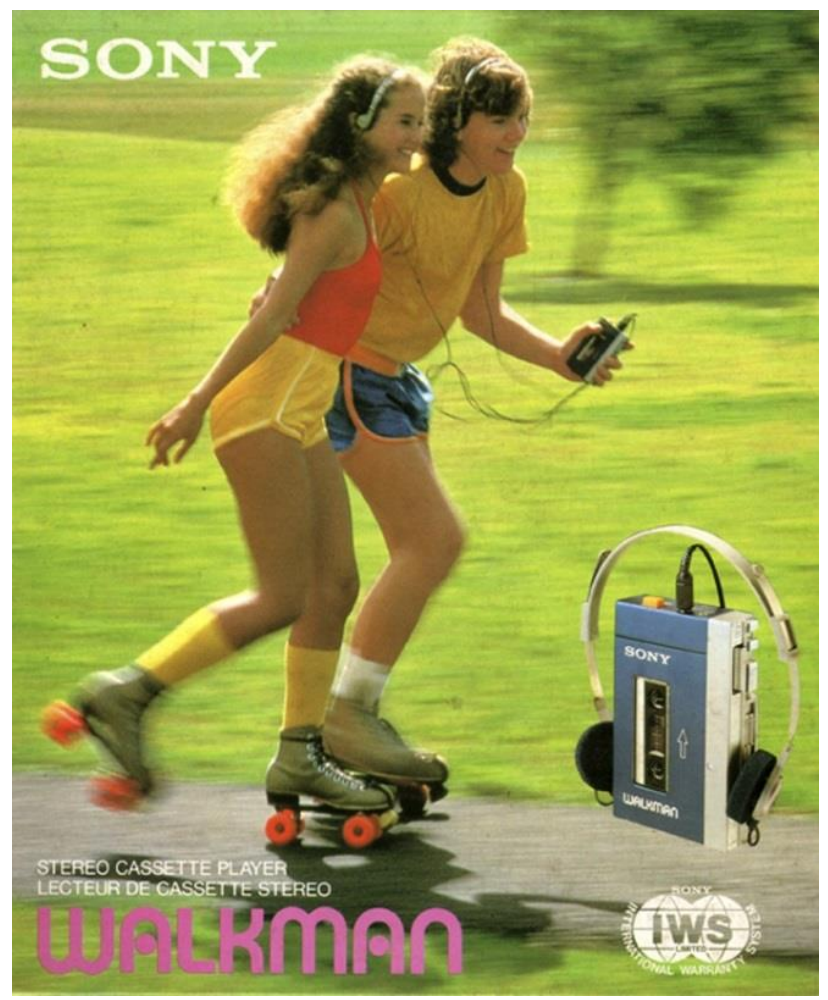

Crédito: Shari Sentlowitz
Figura 5: Anytime, anywhere, anybody. Anúncio Walkman (1981)

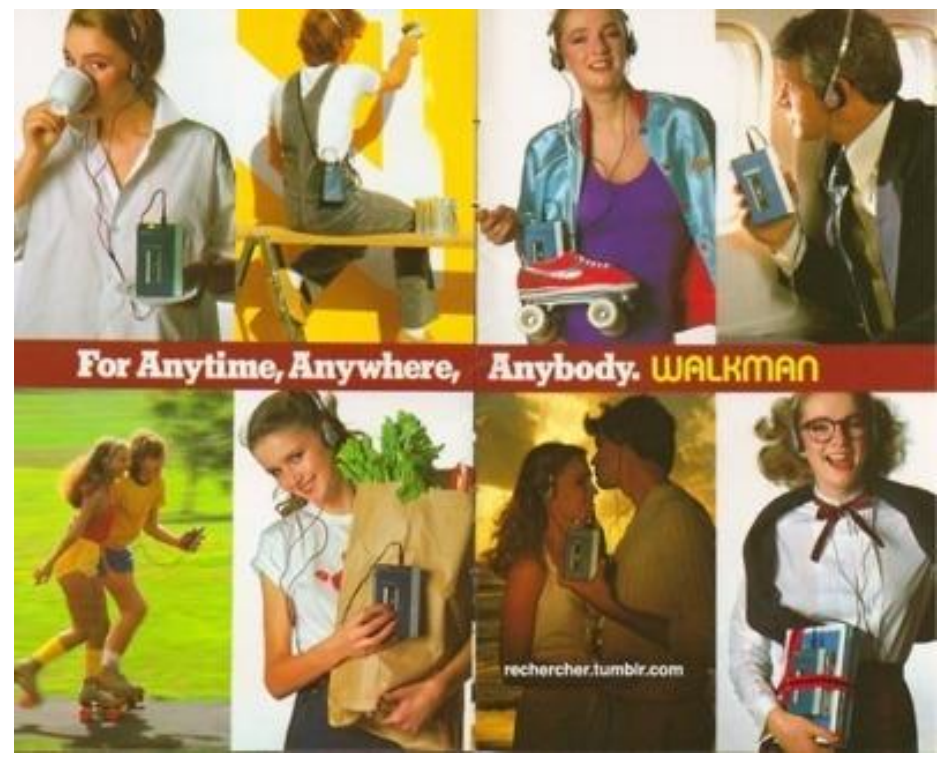

Crédito: Angela Shah
Figura 6: Anúncio Walkman (1987)

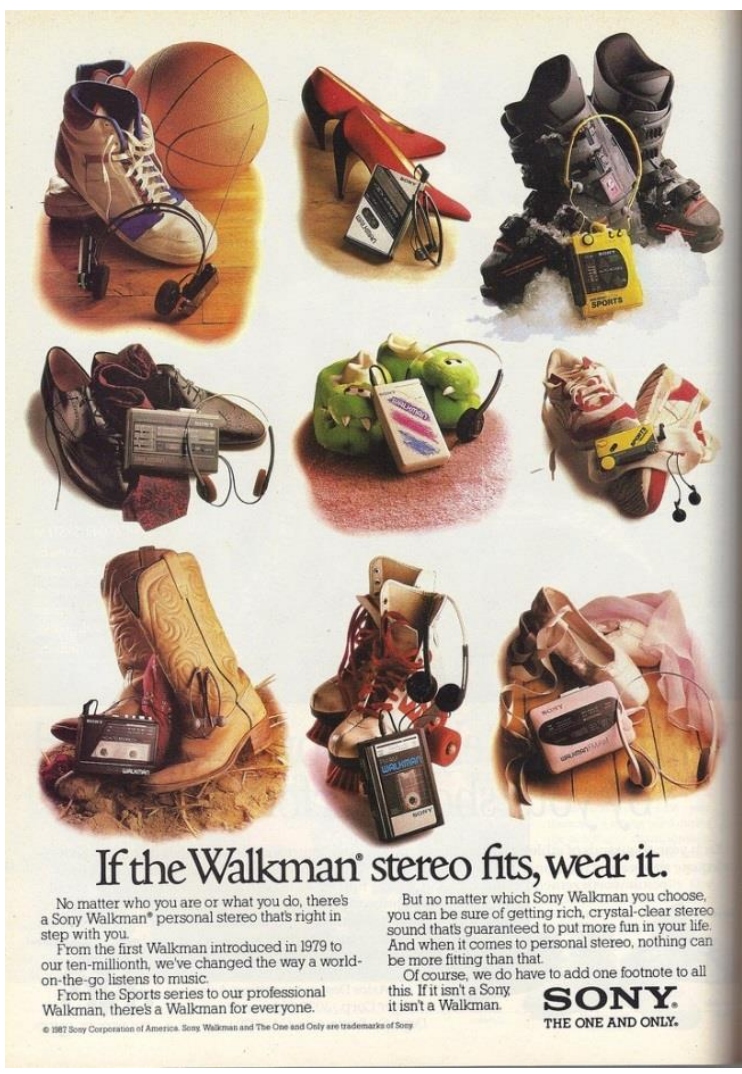

Crédito: Jennifer Boyer 


\section{Referências}

As citações em língua inglesa foram traduzidas pelo próprio autor do trabalho.

ABRAMS, R. M. 1995. Some aspects of the fetal sound environment In: DELIÈGE, I.; SLOBODA, J. A. (eds.), Perception and cognition of music, 83-101. Philadelphia: Psychology Press.

ADLER, E. 1999. Culture Hasn't Been the Same Since Portable Stereo. 28 de março de 1999. Disponível em: <http://www.reporternews.com/1999/features/culture0920.html> Acesso em 14 mai. 2011.

ADORNO, T. W. (1973) 2011. Introdução à Sociologia da Música: doze preleções teóricas. Trad. Fernando R. de Moraes Barros. São Paulo: UNESP.

Sheed and Ward.

ADORNO, T. W.; SIMPSON, G. 1941. On Popular Music. In: HORKHEIMER, M., ed. Studies in Philosophy and Social Science. New York: Institute of Social Research. V, IX, p. $17-48$.

ALBUQUERQUE, S. M. 2012. O retorno do vinil em plena era digital. Observatório da Imprensa. Campinas, 27 nov. 2012. Disponível em: <http://www.observatoriodaimprensa.com.br/news/view/_ed722_o_retorno_do_vinil_em_ple na_era_digital>. Acesso em 14 fev. 2014.

ANDERSON, C. 2008. The Long Tail: Why the Future of Business is Selling Less of More. New York: Hyperion.

ANDERSON, J.; RAINIE, L. 2009. Ubiquity, Mobility, Security: The Future of the Internet. v.3, New York: Cambria Press.

AP, NEWS LIMITED NETWORK. 2012. Google reveals 'top secret' data centres that act as beating heart of the digital age. 18 de outubro de 2012. Disponível em: <http://www.news.com.au/technology/google-reveals-top-secret-data-centers/story-e6frfro0$1226498166064>$ Acesso em 05 jul. 2013.

APPLE. Disponível em <http://apple-history.com/iphone> Acesso em 13 abr. 2014.

ARISTÓTELES. 2005. A Política. Trad. Torrieri Guimarães. São Paulo: Hemus.

AUDIO TECHNICA. <www.audio-technica.com> Acesso em 12 de fevereiro de 2014.

AUGÉ, M. 1994. Não-Lugares: Introdução a uma antropologia da supermodernidade. São Paulo: Papirus.

BAITEllo JR, N. 1999. "A Mídia Antes da Máquina”. CISC . A Mídia Antes da Máquina . CISC -Centro Interdisciplinar de Semiótica da Cultura e da Mídia. JB Centro Interdisciplinar de Semiótica da Cultura e da Mídia. JB online, caderno Idéias. 16 out. 1999. 
BARBIERO, D. 1989. After the aging of new music. Telos Press. New York, p. 144-150. 21 dez. 1989.

BARROS, M. 2011. A volta dos discos de vinil: lançamentos nacionais, reabertura da única fábrica no Brasil e lojas de raridades impulsionam o mercado de vinis. 28 de janeiro de 2011. Disponível em: <http://vejasp.abril.com.br/materia/a-volta-do-discos-de-vinil〉. Acesso em 12 ago. 2013.

BARROS FILHO, C. 2014. Entrevista no programa Mundo Melhor em 03 de maio de 2014. Disponível em: <http://chalita.com.br/tvchalita/a-vida-que-vale-a-pena-ser-vivida-com-clovisde-barros-filho/> Acesso em 13 mai. 2014

BARTHES, R. 1990. O óbvio e o obtuso: ensaios críticos. $2^{\circ}$ Ed. Rio de Janeiro: Nova Fronteira.

BARTÓK, B. 1985. Escritos sobre a música popular. $3^{\text {a }}$ ed., México: Siglo Veitiune.

BAUMAN, Z. 2003. Modernidade Líquida. Trad. Plínio Dentzien. Rio de Janeiro: Zahar.

Zahar, 2004. Amor Líquido: sobre a fragilidade dos laços humanos. Rio de Janeiro. Jorge 2007. Tempos líquidos. Rio de Janeiro: Jorge Zahar.

2013. A cultura no mundo líquido moderno. $1^{\circ} \mathrm{ed}$. Rio de Janeiro, RJ: Zahar.

BENDIX, R. 2000. "The Pleasures of the Ear: Toward an Ethnography of Listening." Cultural Analysis vol. 1: 33-50.

BERINATO, S. 2010. The iTunes Effect and the Future of Content. Harvard Business Review, jan. 2010. Disponível em: <http://blogs.hbr.org/2010/01/the-itunes-effect-and-thefutu/>. Acesso em 15 mar. 2014.

BERLAND, J. 1998."Locating Listening: Technological Space, Popular Music, and Canadian Mediations." In: The Place of Music, A. Leyshon; D. Matless; G. Revill (Org.). New York: Guildford Press, 129-150.

BLOCK, J. 2008. Issues for DSM-V: Internet Addiction. The American Journal Of Psychiatry, Portland, $\mathrm{n}^{\mathrm{o}} \quad 3$, v. 165, 306-308. 01 mar. 2008. Disponível em: <http://ajp.psychiatryonline.org/article.aspx?articleID=99602>. Acesso em 22 mai. 2013.

BOSE. Disponível em:

<http://www.bose.com/controller?url=/shop_online/headphones/noise_cancelling_headphone s/index.jsp.> Acesso em 15 jun. 2014

BOVILL, M.; LIVINGSTONE, S. 2001. Bedroom culture and the privatization of media use. London: LSE Research online. Disponível em: 〈http://eprints.lse.ac.uk/672/>. Acesso em 19 mai. 2014. 
BRAGA, J. 2012. Obsolescência programada: o consumo exacerbado e o esgotamento de fontes naturais. Revista Humboldt, Goethe-Institut Brasilien, dez. 2012. Disponível em: <http://www.goethe.de/ins/br/lp/kul/dub/umw/pt10282568.htm>. Acesso em 12 jun. 2014.

BULL, M. 1999. "The dialectics of walking: Walkman use and the reconstruction of the site of experience." In: Consuming Cultures: Power and Resistance, J. Hearn; S. Roseneil (Org.). London: Macmillan, 199-220.

2000. Sounding out the City: Personal Stereos and the Management of Everyday Life. Oxford: Berg.

2001. The World According to Sound: Investigating the World of Walkman Users. New Media and Society 3 (2): 209-227.

- 2002. The Seduction of Sound in Consumer Culture: Investigating Walkman Desires. Journal of Consumer Culture 2 (1): 81-101.

2005. No Dead Air! The iPod and the Culture of Mobile Listening. Leisure Studies, $\mathrm{n}^{\circ} 4$ vol. 24, 343-355. Disponível em:

<http://cmap.javeriana.edu.co/servlet/SBReadResourceServlet?rid=1326813529329_1043644 80_2755>. Acesso em 22 out. 2013

CAGE, J. <http://johncage.org/4_33.html>. Acesso em: 16 jun. 2014.

CARNEIRO, M.; ROMAN, C.; FAGUNDEZ, I. 2014. Vendas de smartphones e tablets crescem mais que 100\% em 2013. Folha de São Paulo, 01 jan. 2014. Disponível em: <http://www1.folha.uol.com.br/mercado/2014/01/1391973-vendas-de-smartphones-e-tabletscresceram-mais-que-100-em-2013.shtml> Acesso em: 16 abr. 2014.

CARVALHO, A.; RIOS, R. 2009. O MP3 e o fim da ditadura do álbum comercial. In: PERPETUO, I.; SILVEIRA, S. A. org. O futuro da música após a morte do CD, p. 75-90. São Paulo: Momento Editorial.

CHAMBERS, I. 1994. Migrancy, Culture, Identity. London: Routledge.

CHEN, Shing-Ling. 1993. The Self, the Community, and the Electronic Media. Tese de doutorado, University of Iowa, Iowa.

CHOW, R. 1999. "Listening Otherwise, Music Miniaturized: A Different Type of Question About Revolution." In: The Cultural Studies Reader, (Ed.) During, S. London:

Routledge, 462-476.

CIPOLLA, C. M. 1977. História Econômica da População Mundial. Rio de Janeiro, Zahar.

CLUBE DO HARDWARE. Disponível em <http://forum.clubedohardware.com.br/> Acesso em 17 de julho de 2013.

COLI, J. M. 2006. Vissi d'arte por amor a uma profissão: um estudo sobre a profissão do cantor no teatro lírico. São Paulo: Annablume. 
CONNOR, S. 1999. "... or a New Creative Medium?" In: Settling the Score: A Journey Through the Music of the 20th Century, M. Oliver (Org.). London: Faber and Faber, 307-308.

CRANE, R. 2005. Social distance and loneliness as they relate to headphones used with portable audio technology. 2005. Dissertação de Mestrado em Psicologia, Humboldt State University, Humboldt. Disponível em: <http://humboldt-dspace.calstate.edu/handle/2148/28>. Acesso em 04 fev. 2014.

CROWL, H. 2009. A criação musical erudita e a evolução das mídias: dos antigos 78rpms à era pós-CD. In: PERPETUO, I.; SILVEIRA, S. A. org. O futuro da música após a morte do $C D$, p. 143-158. São Paulo: Momento Editorial.

DAVIES, S. 2001. "Anglo-American Philosophy of Music." in The New Grove Dictionary of Music and Musicians, S. Sadie (org.). London: Macmillan. Vol. 19, 621-624.

DEBIAGGI, S, PAIVA, G. (org.). 2004. Psicologia, e/imigração e cultura. Coleção Psicologia Social - Inconsciente e Cultura. Coord: Maria Inês Assumpção Fernandes. São Paulo: Casa do Psicólogo.

DE MARCHI, L. 2005. A angústia do formato: uma história dos formatos fonográficos. Revista E-Compós, n.2, p.1-19, abr. 2005.

DeNORA, T. 2000. Music in Everyday Life. Cambridge: Cambridge University Press.

DELl'ANTONIO, A. 2004. (Org.) Beyond Structural Listening? Postmodern Modes of Hearing. Berkeley, Los Angeles and London: University of California Press.

DOWNEY, R. s/d. Headphone Music on the Move: The Walkman and iPod become Fashion. Disponível em <https://www.academia.edu/2243012/Headphone_Music_on_the_Move_The_Walkman_and_ iPod_become_Fashion>. Acesso em 22 de abril de 2014.

DuGAY, P. 1997. Doing Cultural Studies: The Story of the Sony Walkman. London: Sage Publications.

EISENBERG, E. 1988. The Recording Angel: The Experience of Music from Aristotle to Zappa. New York: Penguin Books.

ELBERSE, A. 2010. Bye-Bye Bundles: The Unbundling of Music in Digital Channels. Journal of Marketing: Maio 2010, Vol. 74, No. 3, pp. 107-123.

ESTADO DE SÃO PAULO. 2012. MP3 supera o CD no Reino Unido. Estado de São Paulo, 02 jun. 2012. Disponível em <http://www.estadao.com.br/noticias/impresso,MP3-supera-ocd-no-reino-unido,880835,0.htm>. Acesso em 19 abr. 2013.

FÉ, A. M. 2004. Sony paga milhões a suposto inventor do Walkman. Revista Info Online, 07 jun. 2004. Disponível em: <http://info.abril.com.br/aberto/infonews/062004/07062004-1.shl>. Acesso em 12 jun. 2014. 
FISHMANN, R. 2014. Apple Brasil é condenada em processo que a acusa de ter feito obsolescência programada com o iPhone 3G. MacMagazine, 25 abr. 2014. Disponível em: $<$ http://macmagazine.com.br/2014/04/25/apple-brasil-e-condenada-em-processo-que-a-acusade-ter-feito-obsolescencia-programada-com-o-iphone-3g/>. Acesso em 12 jun. 2014.

FLUSSER, V. 2008. O universo das imagens técnicas: elogio da superficialidade. São Paulo: Annablume.

FOLHA DE SÃO PAULO. 2013. 94\% dos jovens britânicos preferem ficar sem sexo do que sem celular. 202013.2 mai. Disponível em: $<$ http://f5.folha.uol.com.br/humanos/2013/05/1281834-94-dos-jovens-britanicos-preferemficar-sem-sexo-do-que-sem-celular.shtml> Acesso em 18 de junho de 2013.

FRANKL, V. 2009. Em busca de um sentido: um psicólogo no campo de concentração (1984). 28 a ed. Trad. Walter Schulupp; Carlos Aveline. Petrópolis: Sinodal; Editora Vozes.

GARCÍA-CANCLINI, N. 2006. Culturas Híbridas: estratégias para entrar e sair da modernidade. $4^{\text {a }}$ Ed. São Paulo: EDUSP.

GAVIN, C. O Som do Vinil. Canal Brasil. Disponível em: $<$ http://canalbrasil.globo.com/programas/o-som-do-vinil/index.html>. Acesso em 16 jun. 2014.

GORRITTI, E. 2013. Viciado em internet não sai de casa há cinco anos no Espírito Santo. Disponível em: <http://g1.globo.com/espirito-santo/noticia/2013/05/viciado-eminternet-nao-sai-de-casa-ha-cinco-anos-no-espirito-santo.html>. Acesso em 22 mai 2013.

GUMPERT, G. 1987. Talking Tombstones and Other Tales of the Media Age. New York: Oxford University Press.

HERSCHMANN, M. 2007. Lapa: cidade da música. Rio de Janeiro: Mauad Editora.

HOSOKAWA, S. 1984. “The Walkman Effect." Popular Music 4: 165-180.

IAZZETTA, F. 2009. Música e mediação tecnológica. São Paulo: Perspectiva: Coleção Signos: FAPESP.

A importância dos dedos para a música feita nas coxas. 2006. Anais do $15^{\circ}$ Congresso da Anppom. Rio de Janeiro: Anppom - Associação Nacional de Pesquisa e PósGraduação em Música, 2005. v. 1, p. 1238-1245.

- Tecnologia, escuta e conflito de gêneros. 2003. Anais do XIV Congresso da ANPPOM, Porto Alegre, 18 a 21 de agosto de 2003, publicação em CD-ROM, 7 pp.

INGRAM, M. 2010. Mary Meeker: Mobile internet will soon overtake fixed internet. GigaOm, 12 abr. 2010. Disponível em: <http://gigaom.com/2010/04/12/mary-meeker-mobileinternet-will-soon-overtake-fixed-internet/> Acesso em 16 abr. 2014.

JOBS, S. iPod Promotional Video. Disponível em: <http://www.youtube.com/watch?v=e84SER_IkP4>. Acesso em 13 mar. 2014 
KAHNEY, L. 2010. John Sculley On Steve Jobs, The Full Interview Transcript, Cult of Mac, 14 out. 2010. Disponível em:

<http://www.cultofmac.com/john-sculley-on-steve-jobs-the-full-interview-transcript/63295>. Acesso em 13 mar. 2014

KAPLÚN, M. 1978. Producción de programas de radio: el guion, la realización. Quito: CIESPAL.Colección Initiyán.

KRAUT, R., PATTERSON, M., LUNDMARK, V., KIESLER, S., MUKOPADHYAY, T., \& SCHERLIS, W. 1998. Internet paradox: A social technology that reduces social involvement and

psychological well-being? American Psychologist, $\mathrm{n}^{\circ} 53$ Vol. 9, 1017-1031. Disponível em: <http://kraut.hciresearch.org/sites/kraut.hciresearch.org/files/articles/kraut98-

InternetParadox.pdf >. Acesso em 12 nov. 2013

LEMOS, R. 2012. Futuros Possíveis - Mídia, Cultura, Sociedade, Direitos. Rio de Janeiro: Editora Sulina.

LENNEBERG, H. 1958. Johann mattheson on affect and rhetoric in music. Journal Of Music Theory. New Haven, p. 47-84. Disponível em: <http://charles.arden.free.fr/wpcontent/uploads/Johann Mattheson on Affect and Rhetoric in Music (I).pdf>. Acesso em 06 abr. 2014.

LERNER, M. 1986. Surplus powerlessness. Oakland, CA: The Institute for Labor and Mental Health.

LÉVY, Pierre. 2010. Cibercultura (Trad. Carlos Irineu da Costa). $3^{\text {a }}$ ed. São Paulo: Editora 34.

LIMA, L. C. (Org.) 1978. Teoria da Cultura de Massa. $2^{\circ}$ ed. Rio de Janeiro: Paz e Terra.

LIND, R. 1989. You Can Take It With You: Uses and Gratifications of the Personal Stereo. Dissertação de mestrado, University of Minnesota, Minnesota.

MATTHESON, J. 1981. Der Vollkommene Capellmeister (1739): A Revised Translation with Critical Commentary. Trad. E. C. Harriss; Ann Arbor, Michigan: UMI Research Press.

McKEON, N.; POLLAN, C. 2006. "A Complete Christmas: Great Gifts-107 ideas for the wardrobe, the table, the mind, and just for the hell of it." New York Magazine,

December 7, 2006, 33-53.

McLUHAN, M. [1964] 1974. Os meios de comunicação como extensões do homem. São Paulo: Cultrix.

MEHMARI, A. 2009. Em meio à música. In: PERPETUO, I.; SILVEIRA, S. A. org. O futuro da música após a morte do CD, p. 207-216. São Paulo: Momento Editorial.

MENEZES, J. E.O. 2007. Rádio e cidade: vínculos sonoros. São Paulo: Annablume. 
21, p. 111-118.

2008. Cultura do ouvir: vínculos sonoros na contemporaneidade. Líbero. Ano XI, n.

MERRIAM, A. 1964 The Anthropology of Music. Evanston, Illinois: Northwestern University Press.

MILLARD, A. 2005. America on record: a history of recorded sound. New York: Cambridge University Press.

2002. Tape recording and music making. In: BRAUN, H.(Org). Music and

technology in the twentieth century. Baltimore: Johns Hopkins University Press, p.158-167.

MOCHILEIROS. Disponível em <http://www.mochileiros.com/> Acesso em 17 jul, 2013.

MOEBIUS, H.; MICHEL-ANNEN, B. 1994. Colouring the Grey Everyday: the Psychology of the Walkman. Free Associations, vol. 4, 570-576.

MORITA, A. 1986. Made in Japan: Akio Morita and Sony. New York: E. P. Dutton,

MORRIS, J. 1989. Pleasures of a Tangled Life. London: Barrie and Jenkins.

MORRIS, C; ROSTRON, J. 2008. Sleeveface: Be the vinyl. New York: Artisan.

MOSCARITOLO, A. 2013. iPhone 5s Line Stretches Around the Block at NYC Apple Store. 20 set. 2013. Disponível em <http://www.pcmag.com/article2/0,2817,2424635,00.asp> Acesso em 16 abr. 2014.

MUZAK. Disponível em: <http://www.muzak.com/>. Acesso em 25 de agosto de 2012.

NATURE SOUNDS. Disponível em: <http://naturesounds.in>. Acesso em 30 de maio de 2014.

NATHAN, J. Sony. 1999. Boston: Houghton Mifflin Company.

NEGUS, K. 1992. Producing Pop: Culture and Conflict in the Popular Music Industry. London: Hodder and Stoughton.

OBICI, G. 2008. Condição de escuta: mídia e territórios sonoros. Rio de Janeiro: 7 Letras.

PERPETUO, I.; SILVEIRA, S. 2009. (Org). O futuro da música após a morte do CD. São Paulo: Momento Editorial.

PETERSON, R. 2013. Changing arts audiences: capitalizing on omnivorousness. Workshop Cultural Policy Center, Universidade de Chicago. Disponível em: <http://culturalpolicy.uchicago.edu/papers/workingpapers/peterson1005.pdf>. Acesso em: 22 mai. 2014

PINHEIRO, C. 2009. Mudanças dos ventos à vista. In: PERPETUO, I.; SILVEIRA, S. A. org. O futuro da música após a morte do CD, p. 193-206. São Paulo: Momento Editorial. 
QUINES, S. 2012. Admirável vinil novo: o retorno dos discos na era do MP3. Contemporânea, Rio de Janeiro, v. 10, n. 20, p.89-101, 01 jul. 2012. Disponível em: <http://www.e-publicacoes.uerj.br/index.php/contemporanea/article/view/3176>. Acesso em 14 mar. 2014.

REDOLFI. Disponível em <http://www.redolfi-music.com/index_n.htm>. Acesso em 20 julh. 2013.

REHN, A. 2008. Wittengenstein's iPod, or, The Familiar among Us, In: iPod and Philosophy: iCon of an ePoch (Org.) D. E. Wittkower, Chicago: Open Court.

RETONDAR, A. M. 2008. A (re)construção do indivíduo: a sociedade de consumo como "contexto social" de produção de subjetividades. Sociedade e Estado, Brasília, v. 23, n. 1, p. 137-160, jan./abr., 2008. Disponível em: 〈http://www.scielo.br/pdf/se/v23n1/a06v23n1.pdf〉. Acesso em 12 set. 2011.

ROSEN, C. 2005. The Age of Egocasting. The New Atlantis. Washington, p. 51-72. jun. 2005. Disponível em: <http://www.thenewatlantis.com/publications/the-age-of-egocasting>. Acesso em 11 jun. 2013.

SÁ, S. 2009. O CD morreu? Viva o vinil! In: PERPETUO, I.; SILVEIRA, S. A. (Org). $O$ futuro da música após a morte do CD, p.49-74. São Paulo: Momento Editorial.

SANDERSON, S.; UZUMERI, M. 1997. Managing Product Families: The Case of the Sony Walkman, in Managing Strategic Innovation and Change: A Collection of Readings, ed. Michael L. Tushman and Philip Anderson. New York: Oxford University Press.

SANDOVAL, G. 2010. Goodbye Walkman, thanks for the iPod. 25 out. 2010. CNET. Disponível em: <http://news.cnet.com/8301-13579_3-20020573-37.html>. Acesso em 13 mar. 2014.

SANTAELLA, L. 1996. O homem e as máquinas, in A cultura das Mídias. São Paulo: Experimento.

2003. Cultura e artes do pós-humano: da cultura das mídias à cibercultura. São Paulo: Ed. Paulus.

2011 Navegar no ciberespaço: $O$ perfil cognitivo do leitor imersivo. $4^{\mathrm{a}}$ ed. São Paulo: Paulus.

2013. Comunicação Ubíqua - Repercussões na Cultura e na Educação. $1^{\mathrm{a}}$ ed. São Paulo, SP: Paulus.

SARTWELL, C. 1999. Happy 20th, Anti-Social Walkman. Lexington Herald-Leader.

Disponível em:

<http://www.kentuckyconnect.com/heraldleader/news/100399/commentarydocs/100

3Walkman.htm>. Acesso em 12 mar. 2013.

SCHAFER, M. 1992. O ouvido pensante. São Paulo: UNESP. 
1997. A afinação do mundo. São Paulo: UNESP.

SCHEFF, T.J. 2004. Universal Human Needs?:After Maslow. University of California, Santa Barbara. Disponível em: < http://www.soc.ucsb.edu/faculty/scheff/32.html> Acesso em 12 nov. 2013.

SCHIMIDT, P. 2009. E agora, o que eu faço do meu disco?. In: PERPETUO, I.; SILVEIRA, S. A. org. O futuro da música após a morte do CD, p. 175-192. São Paulo: Momento Editorial.

SCHÖNHAMMER, R. 1989. The Walkman and the Primary World of the Senses. Phenomenology and Pedagogy Journal. Alberta, p. 127-144. Disponível em: $<$ https://ejournals.library.ualberta.ca/index.php/pandp/article/view/15091/11912>. Acesso em 10 abr. 2014.

SHARWOOD, S. 2014. Selfies are over: Welcome to the age of Sleeveface. 31 de março de 2014. Disponível em:

<http://www.theregister.co.uk/2014/03/31/sleeveface_the_new_selfies/> Acesso em 21 mai. 2014.

SIMMEL, G. 1950. The Metropolis and the Mental Life. (1903). In: WOLFF, K. The Sociology of Georg Simmel. Trad. Kurt Wolff. Illinois: The Free Press. p. 409-424.

SIMUN, M. 2009. My Music, My World: Using the MP3 Player to shape experience in London. New Media and Society, vol. 11, 921-941, set. 2009.

SLEEVEFACE. Disponível em <www.sleeveface.com>. Acesso em 21 de maio de 2014.

Sleeveface - bring life back with old records with a fun photo project. 14 de maio de 2014. Disponível em <http://www.blipfoto.com/blog/2014/05/13/sleeveface-bring-life-backto-old-records-with-a-fun-photo-project>. Acesso em 21 de maio de 2014.

. Sleeveface é bolacha na cara. 26 de maio de 2009. Disponível em $<$ http://www.fiamfaam.br/momento/?pg=leitura\&id=1613\&cat=1>. Acesso em 21 de maio de 2014.

SLOBODA, J. 1999. "Everyday Uses of Music Listening: A Preliminary Study." In Music, Mind, and Science. S. W. Yi (Org.). Seoul: Seoul National University Press, 354-369.

2001. "Affect." In: The New Grove Dictionary of Music and Musicians, Ed. S. Sadie. London: Macmillan. Vol. 20, 544-546.

STERNE, J. 2012. MP3: The Meaning of a Format. Durham, NC: Duke University Press.

STOCKFELT, O. 2004. Adequate Modes of Listening. In: Cox, C.; Warner, D. (org.). Audio Culture: Readings in Modern Culture. New York/London: Continuum.

SUBOTNIK, R. R. 1988. Toward a deconstruction of structural listening: A critique of Schoenberg, Adorno and Stravinsky. In: NARMOUR, E.; SOLIE, R. (eds.). Explorations in 
music, the arts, and ideas: Essays in honor of Leonard B. Meyer, p. 87-122. Stuyvesant, New York: Pendragon Press.

1996. Deconstructive Variations: Music and Reason in Western Society. Minessota: Minessota Press.

SZENDY, P. 2008. Listen: A History of Our Ears. Trad. Charlotte Mandell. $3^{\text {a }}$ ed. Fordham University Press, New York.

TATIT, L. 2004. O século da canção. São Paulo: Ateliê Editorial.

THOMAS, B. 1999. Walkman Turns 20 And Nobody Cares [electronic newspaper]. Tired News. Disponível em: <http://tirednews.virtualave.net/technology/7/story_t7141.html>. Acesso em 14 nov. 2012.

THOMAS, S. 2014. Portability and the Era of Mobile Moments. The Hub, 21 jan. 2014. Disponível em: <https://www.swmediagroup.com/what2watch-portability-and-the-era-ofmobile-moments/> Acesso em 16 abr. 2014

TRUAX, B. 2001. Acoustic Communication. $2^{\circ}$ ed., Westport: Ablex Publishing.

THECHIVE. 2012. Vinyl records are making a comeback through sleeveface art. 18 mai. 2012. Disponível em

$<$ http://thechive.com/2012/05/18/vinyl-records-are-making-a-comeback-through-sleevefaceart-40-photos/>. Acesso em 21 mai. 2014.

VALENTE, H. D. 2004. O espírito do tempo, os tempos do espírito: nos (com)passos dos beats dos hits. In: CONTRERA, M. S.; GUIMARÃES, L.; PELEGRINI, M.; SILVA, M. R. (Org.). O espírito do nosso tempo. São Paulo: Annablume Editora Comunicação, p. 189-204.

1999. Os cantos da voz: entre o ruído e o silêncio. $1^{a}$ ed. São Paulo: Annablume Editora-Comunicação.

VARELLA, J. 2010. Barulho no metrô de São Paulo chega a ter intensidade de show de rock. 21 jun. 2010. Disponível em: <http://noticias.r7.com/sao-paulo/noticias/r7-testoubarulho-no-metro-de-sp-chega-a-ter-intensidade-de-show-de-rock-20100621.html> Acesso em 28 mar. 2014.

WARTORN: 1861 - 2010. 2010. Direção de Jon Alpert; Ellen Goosenberg; Matthew O'neill. Produção de Jon Alpert; Ellen Goosenberg; Matthew O'neill. Realização: HBO. S.I: HBO.

WAULKING SONGS. Disponível em: <http://www.houseofscotland.org/waulking.html>. Acesso em 06 jun. 2014.

WEISS, R. S. 1973. Loneliness: The experience of emotional and social isolation. Cambridge, MA: MIT Press.

WESTLAKE, W. 2014. The Ubiquity of Cloud Technology. The Guardian. Disponível em: <http://www.theguardian.com/media-network-partner-zone-huawei/cloud-technologyubiquity>. Acesso em 16 mai. 2014 
WILliAMS, A. 2007. Portable Music and its Functions. New York: Peter Lang Publishing.

WILlIAMSON, J. 1988. Consuming Passions: The Dynamics of Popular Culture. London: Marion Boyars.

WISNIK, J. M. 1999. O som e o sentido: uma outra história da música. $2^{\circ}$ ed. São Paulo: Cia das Letras / Círculo do Livro.

WU, Tim. 2012. Império da comunicação: do telefone à internet, da AT\&T ao Google. Rio de Janeiro: Zahar.

WULF, C. 2007. O ouvido. in Ghrebh, Revista de Comunicação, cultura e teoria da mídia, n. 9, mar. 2007. Disponível em:

<http://www.cisc.org.br/revista/ghrebh9/artigo.php?dir=artigos\&id=WulfPort >.Acesso em 25 jun. 2012.

ZITO, T. 1981. Stepping To the Stereo Strut: On the Run With The Sony Walkman, The Washington Post, May 12, 1981, sect. B1-B2.

Entrevistas:

CASOY, Sergio. Entrevista concedida a Heloísa Valente e Marta Fonterrada. São Paulo, 31 out. 2012.

SILVA, Thereza. G. 2013. Entrevista concedida a Otávio Santos. Londrina, PR, Brasil. 20 mar. 2013.

SANTOS, Leadyr. N. 2013. Entrevista concedida a Otávio Santos. Londrina, PR, Brasil. 23 mar. 2013.

Figuras:

Figura 01: Capa do álbum Slug Line, de John Hiatt (1979). MCA Records, Holanda. Direção de Arte: John Van Hamersveld. Foto: Nick Rosza. Disponível em:

<http://www.discogs.com/viewimages?release=1838859>. Acesso em 21 mai. 2014

Figura 02: Sleeveface com capa do álbum True Blue, de Madonna (1986). Sire / Warner Bros, Estados Unidos. Crédito: Luise Peeck

Disponível em: <http://www.sleeveface.com/?p=3411> Acesso em 21 mai. 2014.

Figura 03: Rothman Wilson: Great Sony Walkman TV and Print Ads of the 1980s. Disponível em:<http://gizmodo.com/5305177/great-sony-Walkman-tv-and-print-ads-of-the-1980s>. Acesso em 16 jun. 2014. (autor original desconhecido)

Figura 04: Angela Shah. Disponível em:

<http://www.pinterest.com/pin/39899146673248277/>. Acesso em 16 jun. 2014. (autor original desconhecido) 
Figura 05: Shari Sentlowitz. Disponível em:

<http://www.pinterest.com/pin/87468417732693166/>. Acesso em 16 jun. 2014. (autor original desconhecido)

Figura 06: Jennifer Boyer. Disponível em:

<http://www.pinterest.com/pin/115686284149925582/>. Acesso em 16 jun. 2014. (autor original desconhecido) 